Historic, archived document

Do not assume content reflects current scientific knowledge, policies, or practices. 



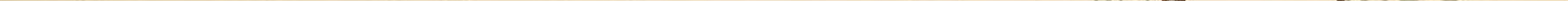


Wm. Elliott \& Sons' . .1896.

\section{CATALOGUE}

TO BE PLANTED NOW FOR GOOD RESULTS DURING WINTER AND SPRING

\section{WM. ELLIO'T'T \& SONS,}

Importers of Bulbs and Seeds,

54 and 56 Dey Street, NEW YORK. 


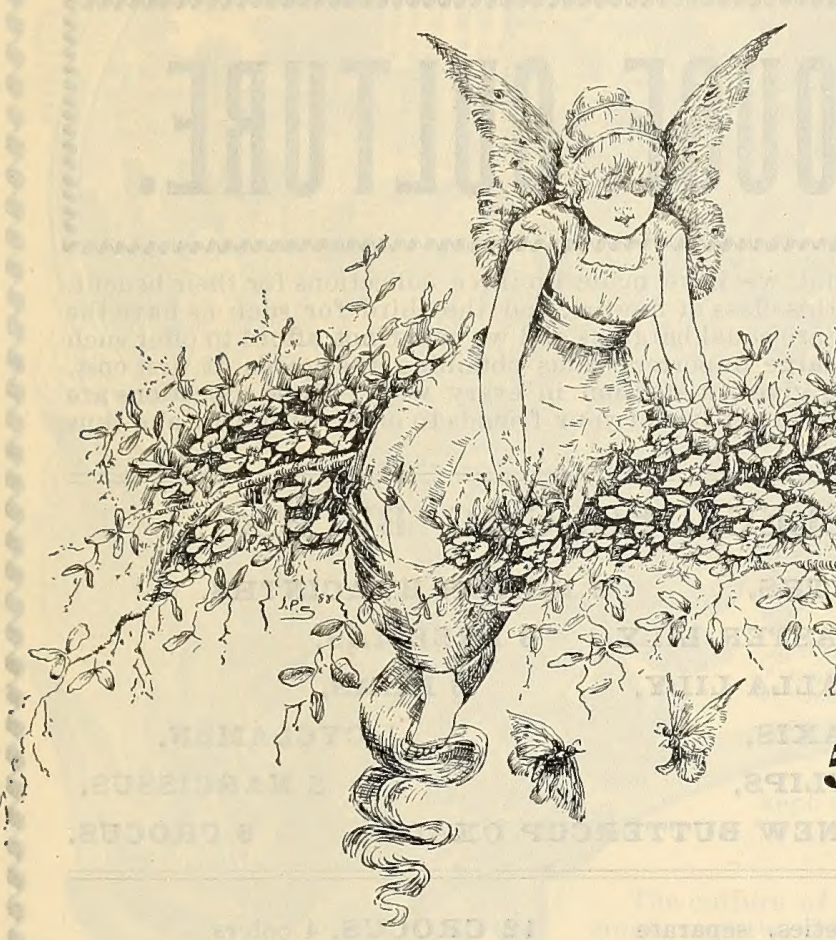

\section{4 \& 56 Dey Street,}

NEARLY all bulbs herein offered are ready for delivery the second week in September. A few kinds are not matured sufficiently for shipment until November; these are so noted.

Please NOTE.-A11 General Orders will be shipped as soon as received, and the NovemBER BUlbs will be forwarded as soon as ready. Should you wish us to hold your general order until November bulbs are ready PLEASE SO STATE when ordering.

BULBS BY MAIL.-Do not neglect to add postage as indicated when bulbs are ordered by mail, otherwise we will be obliged to reduce the quantity sufficiently to cover cost of mailing; some few varieties are mailed free at single and dozen rates, but these are so noted. Large quantities go by express or freight, according to instructions.

REMITTANCES.-Remittances may be made AT our RISk by Bank Draft, Post Office Money Order, Express Order or Registered Letter. Small amounts may be sent by ordinary mail, and postage stamps can always be used by us to advantage (ore and two cent denominations preferred). 


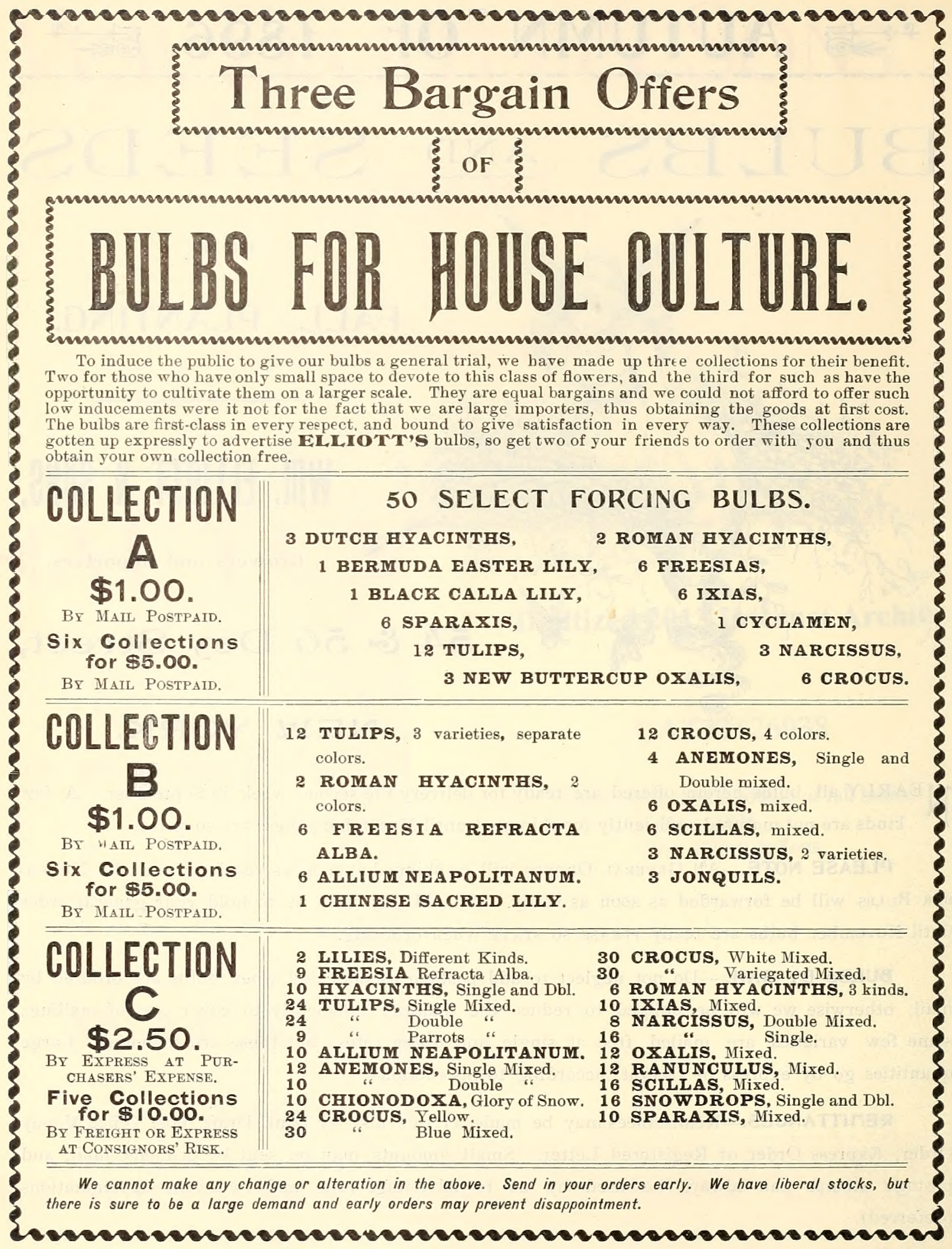




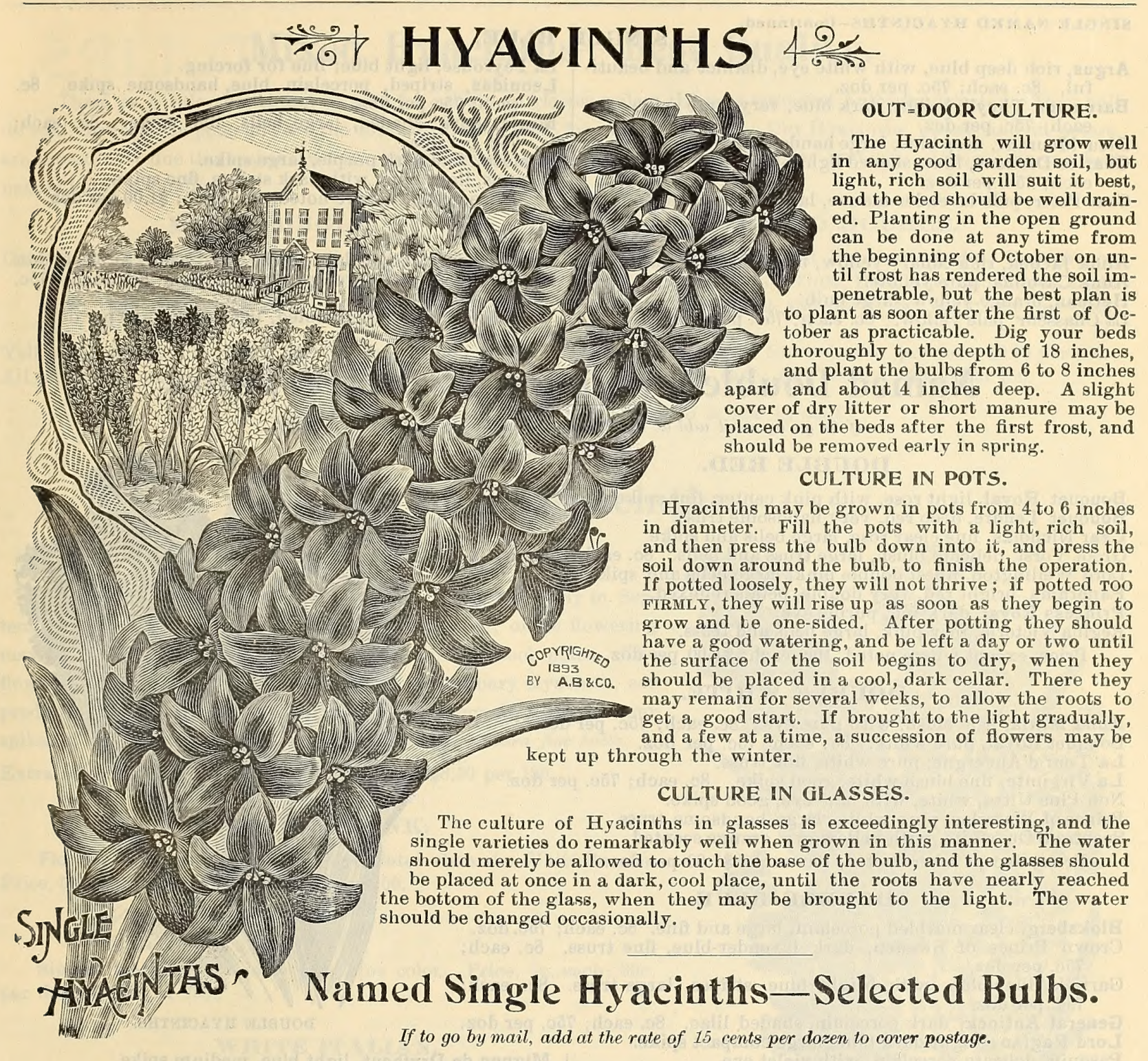

\section{SINGLE RED.}

Amy, deep carmine, close fine spike. 8c. each; 75c. doz. Gigantea, delicate rose, immense spike. Jenny Lind, fine red, good truss.

L'Amie de Coeur, dark red, moderate truss.

Norma, delicate waxy pink, early, fine truss.

Queen of Hyacinths, rich, rosy scarlet, handsome spike.
Robert Steiger, bright crimson, fine compact spike. $8 c$ each: 75c. per doz.

Sultan's Favorite, pink, showy spike of flowers.

Veronica, dark, early, large spike. 8c. each; 75c. per doz.

Victoria Alexandriana, vivid crimson, large bells, fine. Price, except where noted, 10c. each; $\$ 1.00$ per doz.

\section{SINGLE WHITE.}

Alba Superbissima, pure white, large compact truss. 8c. each; 75c. per doz.

Baroness von Thuyll, pure white, large compact spike. 8c. each; 75c. per doz.

Grandeur a Merveille, fine pale blush, immense spike. 8c. each; 75c. per doz.

Grand Vedette, pure white, large bells, very early.

La Franchise, creamy white, large bells, fine spike.

Maid of Orleans, pure white, early, good spike.

Mme. Van der Hoop, pure waxy white, fine large bells.

Queen Victoria, pure white, large bells, fine spike.

Voltaire, pale, waxy blush, good spike. 8c. each; $75 \mathrm{c}$. per doz.

Price, except where noted, 10c. each; $\$ 1.00$ per doz. 


\section{SINGLE BLUE.}

Argus, rich deep blue, with white eye, distinct and beautiful. 8c. each; 75c. per doz,

Baron von Thuyll, bright, dark blue, very large spike. 8c. each; 75c. per doz.

Bleu Mourant, deep blue, large handsome truss.

Charles Dickens, lilac, shaded light blue, large truss. 8c. each; 75c. per doz.

Czar Peter, pale lavender-mauve, large bells and spike.
La Peyrouse, light blue; fine for forcing.

Leonidas, striped, porcelain blue, handsome spike. 8c. each; 75c per doz.

Marie, dark shaded, large bells, fine spike. 8c. each; 75c. per doz.

Mimosa, fine dark purple, large spike.

Regulus, light blue, with dark stripes, fine spike. Price, except where noted, 10c. each; $\$ 1.00$ per doz.

\section{SINGLE YELLOW.}

Alida Jacoba, rich canary yellow, fine compact truss.

Anna Carolina, pure yellow.

Herman, orange-yellow, large bulb.

La Chasseur, pale yellow. 8c. each; 75c. per doz.

La Citroniere, citron, large spike. $15 \mathrm{c}$. each; $\$ 1.50$ per doz.

La Pluie d'Or, pale yellow, good spike. 8c. each; 75c. per doz. Price, except where noted, 10c. each; $\$ 1.00$ per doz.

\section{Named Double Hyacinths-Selected Bulbs.}

If to go by mail add at the rate of 15 cents per dozen for postage.

\section{DOUBLE RED.}

Bouquet Royal, light rose, with pink center, fine spike.

Bouquet Tendre, deep red, very handsome truss.

Czar Nicholas, fine clear rose, large bells and spike.

Groot Vorst, delicate blush, large truss and bells. 8c. each; 75c. doz.

Lord Wellington, finest double pink, large bells and spike.

Panorama, bright red, very double, petals reflexed.

Princess Royal, dark red, purple eye.

Regina Victoria, rosy pink, large bells and truss.

Price, except where noted, 10c. each; $\$ 1.00$ per doz.

\section{DOUBLE WHITE.}

Anna Maria, pale blush, with pure eye. 8c, each; 75c. per doz. Bouquet Royal, pure white. 8c. each; 75c. per doz.

La Tour d'Auvergne, pure white, fine truss.

La Virginite, fine blush white, good spike. 8c. each; 75c. per doz.

Non Plus Ultra, white, with blue eye, good spike.

Prince of Waterloo, pure white, large handsome truss.

Sceptre d'Or, white, with yellow eye, orange scented.

Price, except where noted, $10 \mathrm{c}$. each; $\$ 1.00$ per doz.

\section{DOUBLE BLUE.}

Bloksberg, clear marbled porcelain, large and fine. 8c, each; 75c. doz. Crown Prince of Sweden, dark lavender-blue, fine truss, 8c. each; $75 \mathrm{c}$. per doz.

Garrick, lilac-blue, with bright blue stripes, large truss. 8c. each; 75c. per doz.

General Antinck, dark porcelain, shaded lilac. 8c. each; 75c. per doz.

Lord Raglan, bright dark blue, large compact spike.

Pasquin, delicate porcelain, with violet eye.

Prince of Saxe Weimar, dark blue, semi-double, large.

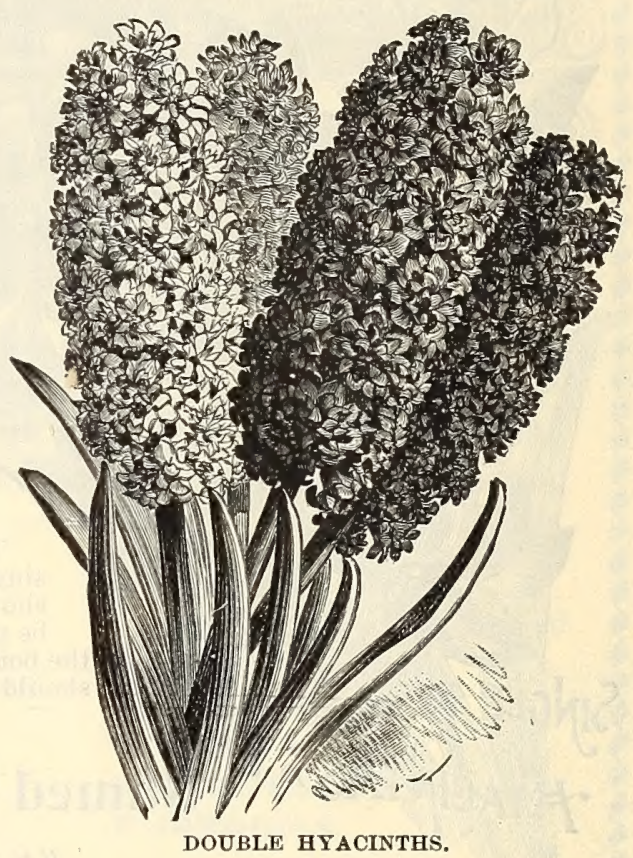

\section{DOUBLE YELLOW.}

Bouquet d'Orange, reddish yellow, medium truss.

Goethe, pale yellow, good truss, large bells. 8c. each; 75 c. per doz.

Jaune Supreme, canary yellow, good spike. 8c. each; 75c. per doz.
Mignon de Dryfhout, light blue, medium spike.

Price, except where noted, 10c. each; $\$ 1.00$ per doz.
Piet Hein, pure yellow, medium spike.

William III., apricot-yellow. 8c. each; 75c. per doz.

Price, except where noted, 10c. each; $\$ 1.00$ per doz.

\section{Choice Named Hyacinths.}

\section{Our Selection of Assorted Varieties, all Named.}

Specially adapted to pot and glass culture. (State whether Singles or Doubles are preferred.)

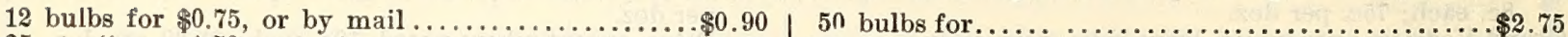

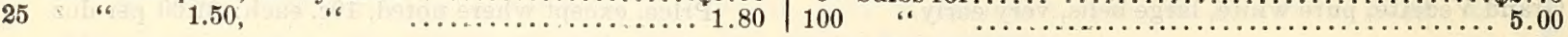

Add 15 cents per dozen to above prices when to be sent by mail. 


\section{Mixed Hyacinths-Best Quality.}

These as a rule should not be used for culture in glasses unless the very strongest bulbs are selected. They will do well, however, in pots, and are the kind invariably used for outside culture. Our Hyacinths, mixed and in colors, are exceedingly fine this season; we can confidently recommend them as true to color and almost equal to the best named bulbs in quality.

\section{MIXED SINGLE.}

Dark Red, Rose, Red and Rose, all shades, Pure White, Blush White and Tints, Dark Blue and Violet, Light

Blue, Blue, light and dark. 6c. each; 50c. per doz.; $\$ 3.25$ per 100 .

Yellow, all shades. 5c. each; 45c. per doz; $\$ 3.25$ per 100 . All colors. 6c. each; 40c. per doz.; $\$ 3.00$ per 100 .

\section{MIXED DOUBLE.}

Dark Red, Rose, Red and Rose, all shades, Pure White, Creamy White and Tints, Dark Blue and Violet, Light Blue, Blue, light and dark. 5c. each; 50c. per doz.; $\$ 3.25$ per 100 .

Yellow, all shades. 5c. each; 50c. per doz.; $\$ 3.75$ per 100.

All colors. 5c. each; 40c. per doz.; $\$ 3.00$ per 100 .

Add 15 cents per dozen to above prices when to be sent by mail.

\section{Roman Hyacinths.}

\section{IMPROVED EARLY WHITE.}

This beautiful and very valuable variety, if planted early in September and gently forced, will bloom in November, or its flowering may be retarded till Christmas by keeping it in a cool place. The flowers, which are smaller than those of the ordinary Hyacinth, are produced in great profusion, each bulb throwing up three or four spikes of delicately scented clear white blossoms. Extra fine bulbs.

Extra selected. Price 8c. each; 60c. per doz.; $\$ 3.50$ per 100 .

\section{ROSE OR PINK.}

Flowers from two to three weeks later than the White Roman. Price, 5c. each; 40c. per doz.; $\$ 2.25$ per 100.

\section{BLUE.}

Similar to the above, of a pale blue color. Price, 5c. each; $30 \mathrm{c}$. per doz.; $\$ 2.25$ per 100 .

\section{WHITE ITALIAN.}

A good forcing variety, somewhat larger than the White Roman. Price, 5c. each; 50c. per doz.; $\$ 2.50$ per 100 .

\section{WHITE MOUNTAIN.}

The best for forcing. Price, 6c. each; 50c. per doz.; $\$ 3.00$ per 100 . Add 10 cents per dozen if ordered by mail.

\section{Miniature Hyacinths,}

or

\section{DUTCH ROMANS.}

Pure White, Pink, Light Blue. 60c. per doz., postage paid.

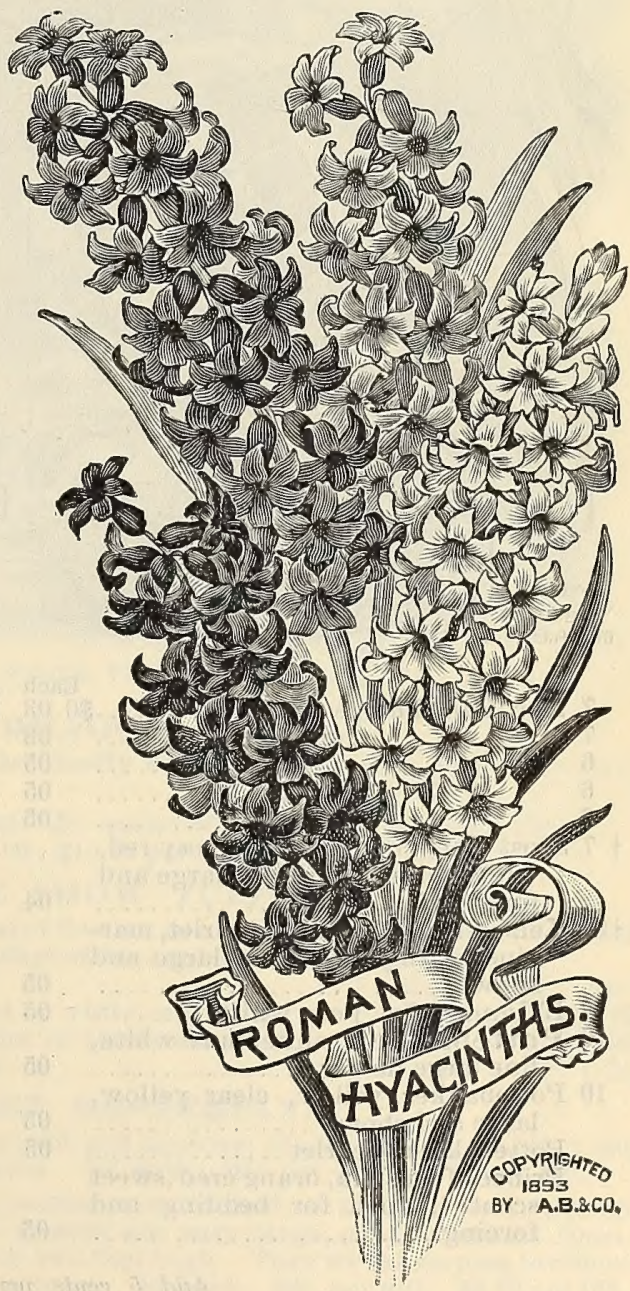




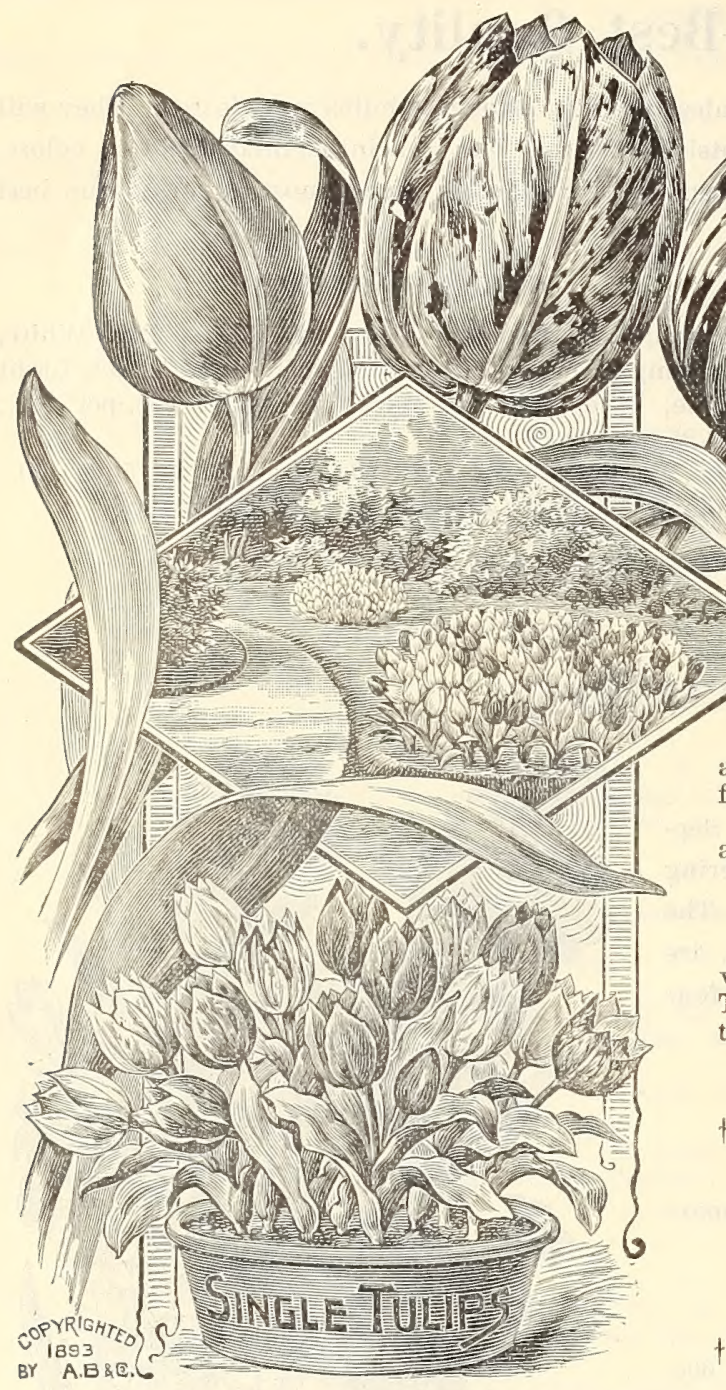

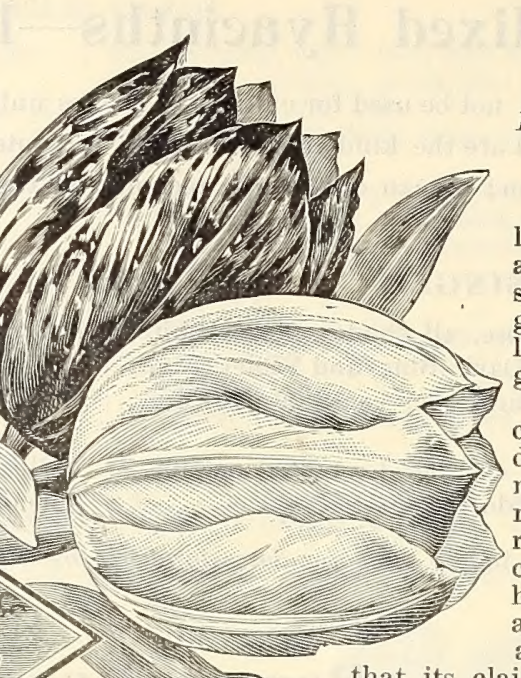
equal to the Hyacinth, Narcissus and Crocus.

For planting in the open ground, Cctober and November are the best months; the bulbs should be planted from five to six inches apart, and from three to four inches deep.

When grown in pots they should be potted from three to five in a pot, the soil and treatment being the same as for Hyacinths.

\section{EARLY SINGLE TULIPS.}

We pay particular attention to this important class, and the varieties named below include some of the finest in existence. Those marked $(\dagger)$ bloom simultaneously, about twelve days later than the Duc Van Thol varieties.

The figures prefixed indicate the height in inches of each variety.

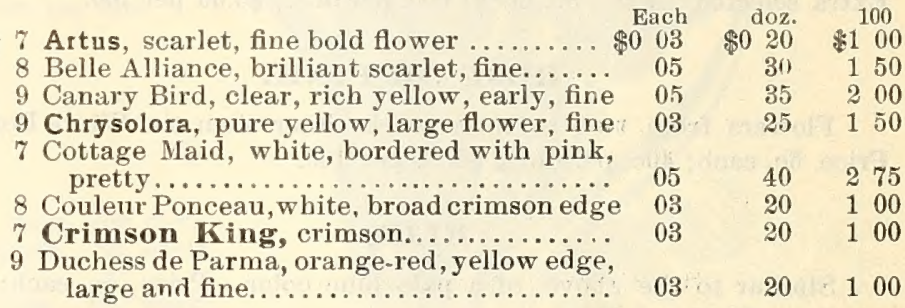

Each doz. 100

7 Duc Van Thol, scarlet.......... $\$ 003 \quad \$ 020$

7 "6 crimson.......... 03

$6 \quad$ " $\quad$ rose............

6 " " white...............

6 " 6 yellow...........

$\uparrow 7$ Joost Van Vondel, glossy rosy red, with white pencilings, large and

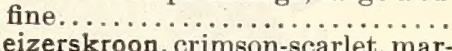

$\nmid 10$ Keizerskroon, crimson-scarlet, margined with yellow, very large and

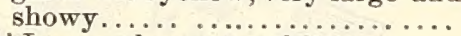

8 L' Immaculee, pure white.........

10 Pottebakker, white, pure white, fine large flower ................

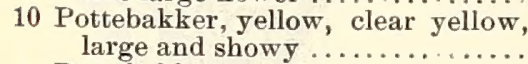

Pottebakker, scarlet ..................
Prince of Austria, orang ered, sweet scented, good for bedding and

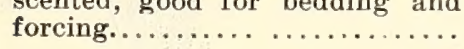

$\begin{array}{rrr}20 & \$ 1 & 00 \\ 20 & 1 & 00\end{array}$

$\begin{array}{lll}30 & 2 & 00\end{array}$

$40 \quad 250$

40250

$04 \quad 25 \quad 175$

$05 \quad 25 \quad 175$

$05 \quad 20 \quad 125$

$05 \quad 40 \quad 250$

$\begin{array}{llll}05 & 50 & 2 & 75\end{array}$

$\begin{array}{llll}05 & 20 & 1 & 50\end{array}$

$05 \quad 45 \quad 300$
† 8 Proserpine, rich, dark rose, Each doz. 100 splendid large flower ............ $\$ 0 \quad 05 \quad \$ 0 \quad 45 \quad \$ 300$ † Queen Victoria (La Reine), white, tinted with rose...............

7 Rembrandt, crimson, large, hand-

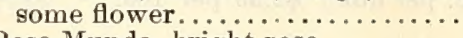

8 Rosa Munda, bright rose.........

+ 8 Rose Grisdelin, delicate rose, shaded white, beautiful ............

† 6 Van der Neer, purplish violet, large flowers, distinct, fine...........

7 Vermilion Brilliant, glossy bright vermilion, large, fine ...........

5 Wouverman, deep violet, splendid

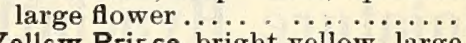

+7 Yellow Pricce, bright yellow, large and showy ................... Extra Fine, Mixed Single Varie-
ties ........... per $1000, \$ 7.00$ ties ........... per $1000, \$ 7.00$

$\begin{array}{lll}03 & 15 & 75\end{array}$

$\begin{array}{lll}03 & 15 & 75 \\ 02 & 10 & 60\end{array}$

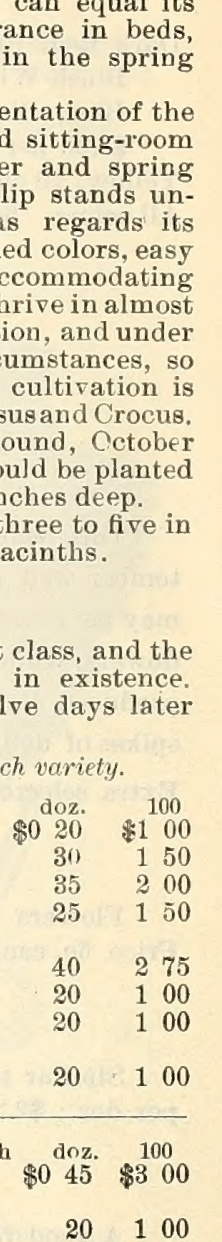
$05 \quad 30 \quad 175$ $\begin{array}{llll}05 & 35 & 200\end{array}$ $05 \quad 40 \quad 250$ $04 \quad 20 \quad 150$ $05 \quad 40 \quad 275$ $05 \quad 20 \quad 100$ $05 \quad 25 \quad 125$ 


\section{PRIZE TULIPS. (See Frontispiece.)}

The three Tulips represented on our cover may be considered to be among the very best single early varieties known. Indeed, they have all the excellent qualities which a really good Single Early Tulip should possess.

Proserpine is of much more recent date than the others; endowed with a rich dark rose in color and a magnificent flower. Keizerskroon (Crown Imperial), with its yellow margin of gold is exceedingly showy. Vermilion Brilliant is of a glossy bright vermilion, exceedingly showy.

\section{DOUBLE TULIPS.}

This very useful and beautiful class, while not equal to the single in brilliancy, lasts much longer in bloom. The earlier varieties, such as Duc Van Thol, Tournesol and Murillo, are excellent for forcing. Many of the other varieties make a fine display when grown in pots, but they require to be forced slowly. The latter sorts, such as La Candeur, Rex Rubrorum, Yellow Rose, etc., are very effective in beds or borders, producing dense masses of bloom of most brilliant colors, which remain in perfection a long time. Each Doz. 100

8 Couronne d'Or, orange-yellow. . $\$ 0 \quad 05 \$ 050 \$ 350$

6 Duc Van Thol, red and yellow, fine forcing................

10 Duke of York, dark rose, bordered with white, very showy.

8 Gloria Solis, rich bronze-crimson,

5 La Candeur, pure white, erect habits, excellent for beds.....

6 Murillo, pale rose and white, distinct and fine.............

9 Rex Rubrorum, bright red, large, showy, excellent for beds.....

7 Salvator Rosa, beautiful deep rose, flamed white..........

7 Titian, red, edged with gold...

8 Tournesol, red and yellow, very beautiful, one of the best for forcing ...................

8 Tournesol Yellow, bright golden-yellow, very fine showy flower, forces well...........

10 Yellow Rose, bright golden yellow, large and showy......

Extra Fine Mixed Double Varieties....... per 1000, $\$ 7.00$ Good Mixed...... per 1000, $\$ 5.00$

$\begin{array}{llll}03 & 20 & 1 & 00 \\ 03 & 20 & 1 & 25 \\ 03 & 25 & 1 & 25 \\ 03 & 25 & 1 & 00 \\ 04 & 40 & 2 & 75 \\ 04 & 35 & 2 & 25 \\ 10 & 50 & 3 & 50 \\ 03 & 25 & 1 & 25 \\ & & & \\ 05 & 35 & 2 & 00 \\ & & & \\ 06 & 45 & 3 & 00 \\ 05 & 20 & 1 & 00 \\ 03 & 15 & & 75 \\ 02 & 10 & 60\end{array}$

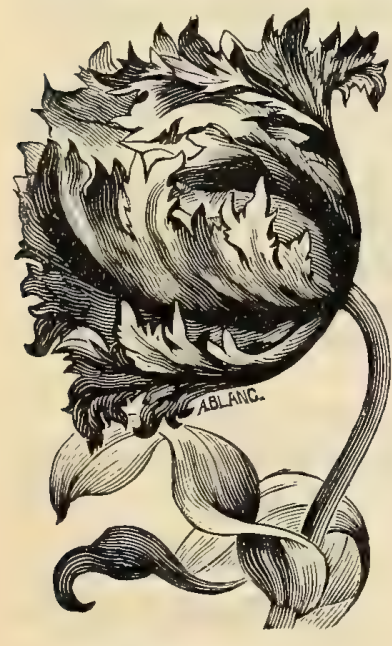

PARROT TULIP.

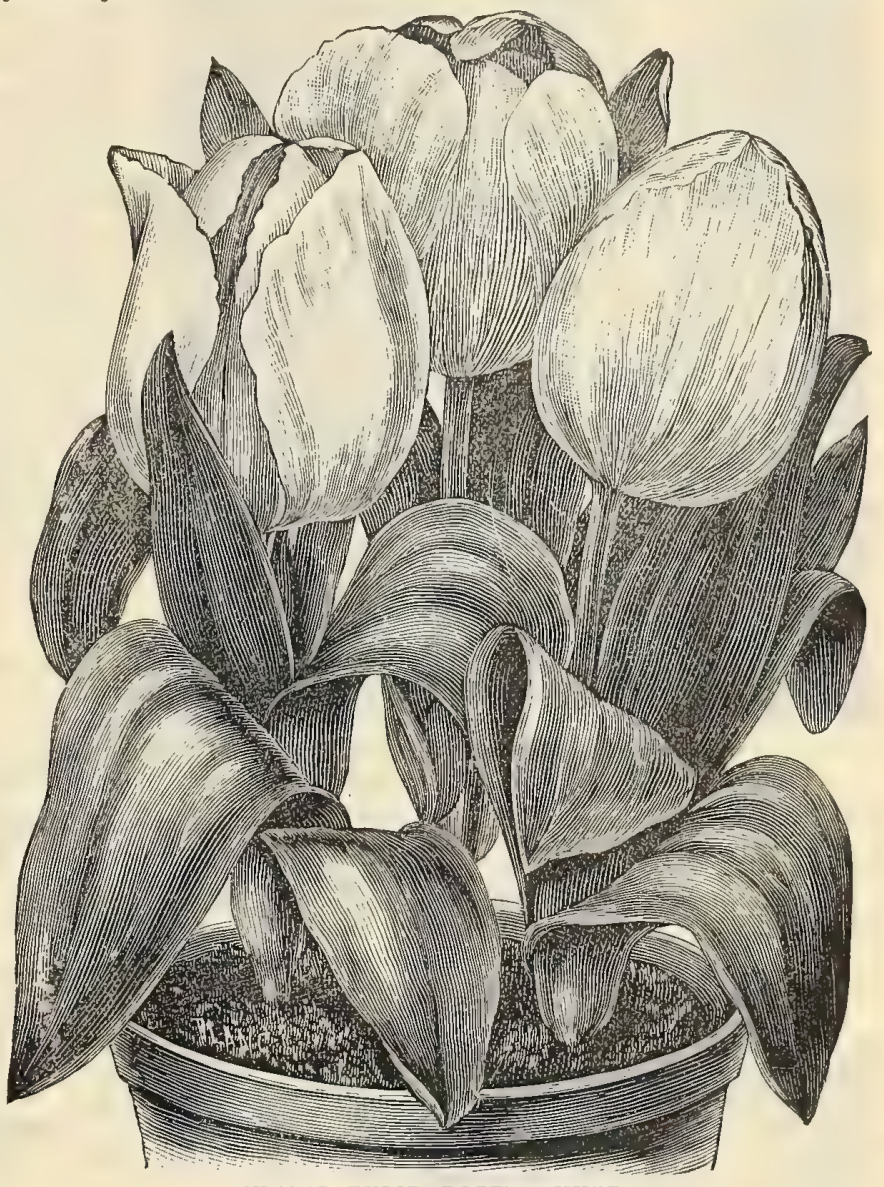

WHITE TULIP POTTEBAKKER.

\section{PARROT OR DRAGON TULIPS.}

A very distinct species, producing brilliantly colored flowers of great size and grotesque shape.

Separate colors, red, yellow and variegated. 5c. each; 25c. per doz.; $\$ 1.75$ per 100 .

Mixed, 3c. each ; 20c. per doz.; $\$ 1.25$ per $100 ; \$ 10.00$ per 1000 .

\section{SINGLE LATE SHOW TULIPS.}

This very beautiful and interesting class of flowers is considerably later than the other sections. They are of taller growth, and adapted for outdoor cultivation only.

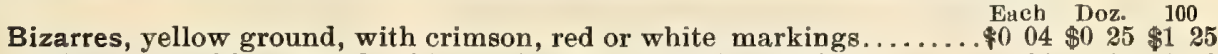

Bybloemens, white ground, with purple, lilac or black markings.......... $04 \quad 25 \quad 1 \quad 50$

$$
\text { " rose ground, white markings........................ } 04.25 \quad 150
$$

TULIP SCARLET GESNERIANA.

Scarlet Gesneriana, the tallest, largest flowered and showiest of all tulips for bedding out in masses; it deserves to be largely grown. 5c. each; 20c. per doz.; $\$ 1.50$ per 100 .

Darwin Tulips belong to the late flowering section, are destined to be extensively grown for bedding or massing purposes. The flowers are very. large, of symmetrical form, and are borne on tall, strong stems, of ten two feet high. They by far surpass in colors and brilliancy anything before known in tulips. 5c. each ; 50c. per doz.; $\$ 3.00$ per 100 .

Add 5 cents per doz.; 40 cents per 100 if to go by mail. 


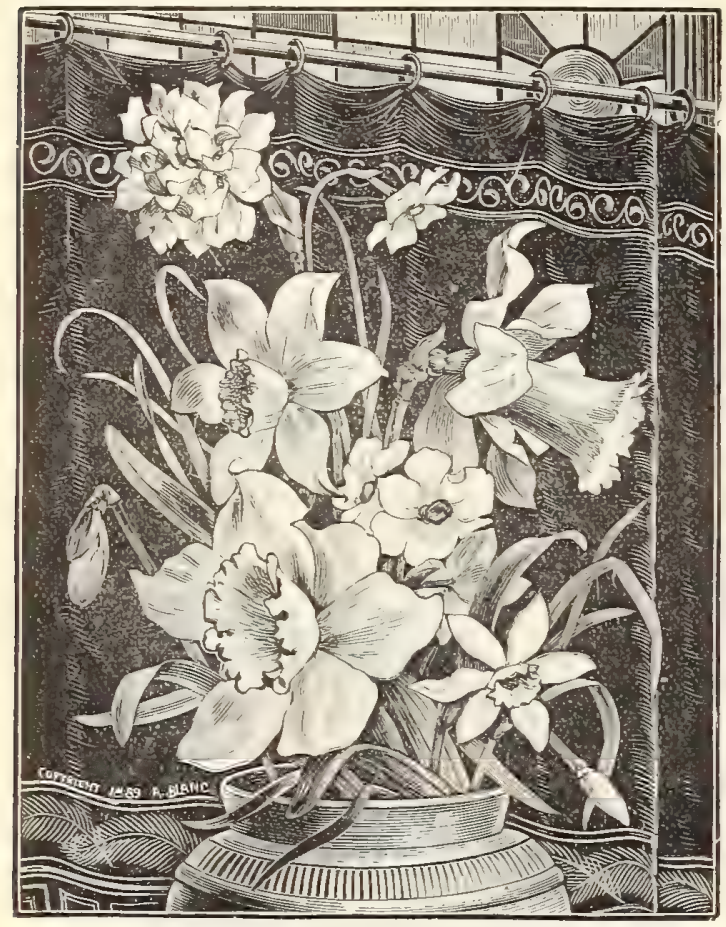

AJAX, OR TRUMPETS.

Yellow Varieties.

Ard Righ or Irish King. Noble flowers, full yellow petals, forces freely. 15c. each; $\$ 1.25$ per doz. ; $\$ 7.00$ per 100 .

Golden Spur. Handsome deep yellow, expanded brim, early. $10 \mathrm{c}$. each ; $\$ 1.00$ per doz.; $\$ 6.00$ per 100 .

Obvallaris. (Tenby Daffodil.) Bright yellow, dwarf; one of the earliest to bloom. 5c. each; 50c. doz; \$3.00, 100 .

Trumpet Major. Trumpet and perianth deep golden yellow, trumpet well opened, recurved and fringed, 5c. each; 30c. per doz.; $\$ 2.00$ per 100.

Henry Irving. A most perfect flower with finely frilled trumpet flowers. Two inch mouth of a rich golden yellow. 10c. each; $\$ 6.00$ per 100 .

Maximus. Darkest and richest yellow of all daffodils, very large. 10c. each: $\$ 1.00$ per doz.

Emperor. One of finest in culture, of immense size. $25 \mathrm{c}$. each; $\$ 2.50$ per doz.

\section{AJAX, OR TRUMPETS.}

\section{Two colored varieties.}

Empress. Best two colcred trumpet; flower large, bold and erect. 25c. each; $\$ 2.50$ per doz.

Grandis. Pure white, imbricated petals, yellow trumpet, superb. 20c. each; $\$ 2.00$ per doz.

Horsfieldii. Petals pure white, fine yellow trumpet, splendid specimen. $10 \mathrm{c}$. each; $\$ 1.00$ per doz.; $\$ 6.50$ per 100 .

Princeps. Magnificent sulphur white petals, yellow trumpet. 5c. each; 50c. per doz.; $\$ 3.00$ per 100 .

Scoticus. Elegant flower, perianth white, trumpet full yellow. 5c, each; 3.5. per doz.; \$2.25 per 100.

\section{WHITE AND SULPHUR TRUMPETS.}

Albicans. Beautiful milk white trumpet daffodils. 10c. each; $\$ 1.00$ per doz.

Pallidus Præcox. One of the most beautiful, perianth and trumpet delicate sulphur. 5c, each; 50c. per doz.; $\$ 3.00$ per 100 .

A3 All the Trumpet Daffotils are valuable for pot culture.

\section{Narcissus or Daffodils.}

HESE charming, graceful flowers have had a great revival of popularity in the last few years, and are now prime avorites for early blooming in the garden, and are largely forced y florists for winter flowers. They are bright and hardy (except the Polyanthus sorts) and nearly all are most deliciously ragrant; no flower better deserves its popularity. Of easy ulture, they are equally satisfactory for potting and for the open bed and horders, where their rush-like glaucous foliage and hite and yellow flowers are very much admired. For their ultivation the soil should be well-loosened so that the roots have erfect freedom in their growth. The planting of bulbs should deep, and about five to ten inches apart.

After the foliage dies down in the summer, the bulbs should e lifted and replanted in September or October in a different lace in the garden; in this way they will thrive and increase rom year to year. Every one should have at least a few of these charming plants.

For house culture plant several bulbs together in a pot and keep in a cool room, give plenty of light and water and they ill bloom in February to April. The Polyanthus varieties are arliest and best adapted to house culture but all will do well in ots if not kept too warm and forced too rapidly.

If desired by mail, add at the rate of 10 cents per dozen to cover ostage. Single bulbs mailed free at prices given.

\section{NARCISSUS LEEDSII.}

(I,eed's Eucharis, Flowered, Chalice Cupped) White Hybrid Daffodils, Beautiful, Sweet-scented.

Amabilis. Large silver white petals, long white crown. 8c, each; 75c. per loz.

Duchess of Brabant. Perianth and cup white, splendid shape. 5c. each; 50c. per doz.

\section{NARCISSUS INCOMPARABILIS.}

\section{Chalice cupped, Nonesuch Daftodils.}

Cynosure. Large primrose petals and cup, the latter orange stained, charming. 8c. each; 50c. per doz.; $\$ 3.00$ per 100.

Sir Walter. Grand chalice flower, immense long stemmed $51 / 2$ inches in circumference. 20c. each; $\$ 2.00$ per doz.

Stella. Early white, golden cup, large handsome flower, petals white. 5c. each; 30c. per doz., $\$ 1.50$ per 100.

\section{NARCISSUS POETICUS.}

Narcissus Poeticus. Pure white, with red crown, very fragrant. 4c. each; 15c. per doz,; 75c. per 100; $\$ 6.00$ per 1000 .

Narcissus Poeticus Ornatus. Blooms one month earlier than the above. 5c. each; 30c. per doz.; $\$ 1.50$ per 100 .

\section{NARCISSUS BIFLORUS.}

Primrose Peerless White Daffodils. Pure white perianth, with soft yellow crown. 4c. each; 20c. per doz; $\$ 1.00$ per 100 .

\section{NARCISSUS CORBULARIA.}

Bulbocodium. Large yellow hoop petticoat, rich golden yellow, distinct dwarf, free flowering variety. 5c. each; 75c. per doz.; $\$ 4.00$ per 100 .

\section{DOUBLE DAFFODILS.}

Incomparabilis. Double light yellow, elegant form. 5c. each; 25c. per doz; ; $\$ 1.50$ per 100.

They are as easily grown as the Hyacinth and should be given roots in $a$ or 4 inch pot. 
DOUBLE DAFFODILS-Continued.

Orange Phonix. "Eggs and Bacon." Beautiful double white flowerg, with orange nectary. Splendid for pot culture and cutting. 3 for $10 \mathrm{c} . ; 50 \mathrm{c}$. doz.; $\$ 3.00,100$.

Poeticus Plenus (Gardenia flowered). Extremely useful and handsome. Each, 5c.; doz., 20c.; 100, $\$ 1.00$.

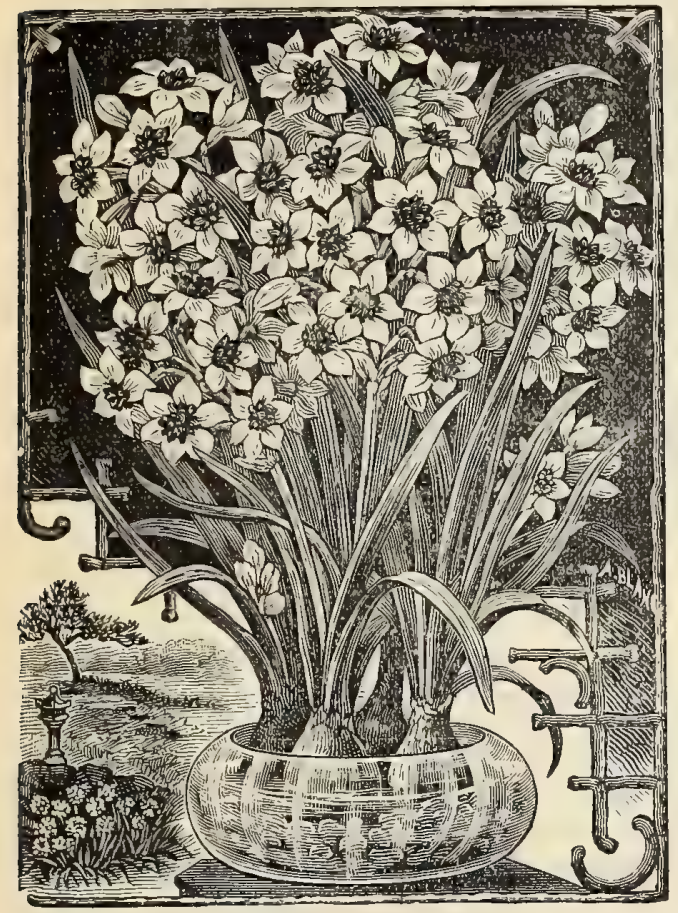

CHINESE SACRED IIILY.

\section{THE CHINESE SACRED LILY, or Oriental Nareissus. (Chinese Grown.)}

A varietv of Polyanthus Narcissus, bearing in lavish profusion, chaste tlowers of silvery white with golden yellow cups; they are of exquisite beauty and entrancing perfume. It is grown by the Chinese according to their ancient custom, to herald the advent of their new year, and as a symbol of good luck.

The bulbs are grown by a method known only to themselves, wherehy they attain great size and vitality, ensuring luxuriant growth and immense spikes of flowers; in fact, the incredibly short time required to bring the bulbs into hloom (four to six weeks af ter planting), is the bulbs into hloom (nature. "Youk an almost see them one "he wonders of nature. "Yoncan almost see them grow," succeeding almost every where and with everybody. They do well in pots of earth, but are more novel enough tancy pebbles to prevent them from topplin. over when in bloom. A dozen bulbs started at intervals will give a succession of flowers through the winter. (See cut).

We are importing direct from China immense bulbs of the true large flowering variety. Price, 10c, ea.; $\$ 1$, doz.

If to be sent by mail add 5c. per bulb or 60c. per dozen to cover postage.

\section{MIXED GROCUS.}

Yellow Doz. $100 \quad 1000$ Blue and Purple ............. $10 \quad 40 \quad 3 \quad 50$ White.................... $10 \quad 40 \quad 350$ Striped and Variegated....... $10 \quad 40 \quad 3 \quad 50$ Mixed, all colors............. $10 \quad 35 \quad 300$ ers.
Sulphur Phœnix. Large creamy white flowers, sulphur nectary, tine for pots. $15 \mathrm{c}$. each; $\$ 1.50$ per doz.

Von Sion (Telamonius Plenus). The old double yellow trumpet datfodil. 5c. each; 40c. per doz.; $\$ 200$ per $100 ; \$ 18.00$ per 1000 .

\section{Polyanthus Narcissus.}

Add 20 cents per dozen to cover postage when ordered by mail.

The varieties of this group produce an abundance of large trusses of very sweet scented flowers, varying in color from pure white to deep golden yellow; they are easily cultivated and excellent for pots and forcing. The Paper White aud Double Roman can be forced into bloom by Christmas.

Paper White, pure white, free flowering, excellent Each Doz. 100

for very early forcing.................... \$0 $05 \quad \$ 0 \quad 25 \$ 1 \quad 25$

New Large Flowering Paper White, this new va.

riety is a great improvement on the old Paper

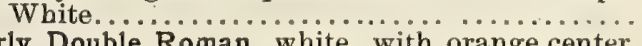

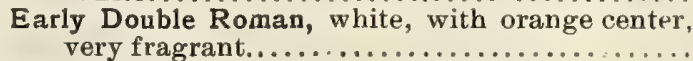

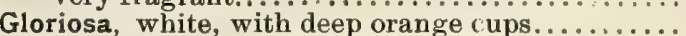
Grand Monarque, white, with pale yellow cups... Soleil d'Or, orange, with yellow cup............

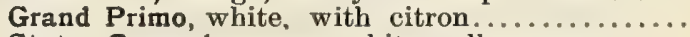

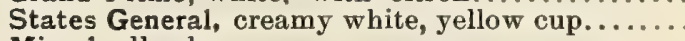

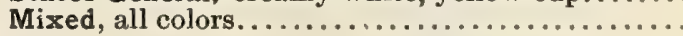

$\begin{array}{llll}05 & 35 & 2 & 00 \\ & & & \\ 05 & 30 & 1 & 75 \\ 05 & 40 & 3 & 00 \\ 06 & 50 & 3 & 50 \\ 06 & 40 & 3 & 00 \\ 05 & 40 & 3 & 00 \\ 06 & 40 & 3 & 00 \\ 05 & 20 & 1 & 00\end{array}$

\section{Jonquils.}

Ten cents per dozen extra by mail.

Pretty flowers prized for their delicate fragrance, graceful habit of growth and profusion of bloom. They are excellent for pot culture, and being perfectly hardy may be planted in open borders, and are exceedingly useful for cutting for bouquets.

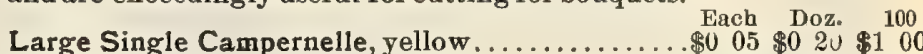
Single Sweet-Scented, deep yellow.............. $05 \quad 20 \quad 100$ Double Sweet-Scented, golden yellow............. $06 \quad 50 \quad 400$

\section{Crocus.}

Five cents per dozen extra by mail.

The Crocus is among the earliest and most popular of spring flowers, and will thrive in al. most any soil or situation.

\section{HYBRID NAMED CROCUS.}

These are composed of all the best and most beautiful varieties, and are remarkable for richness of color and the immense size of their flow-

Baron Brunnow, large

bright purple, large

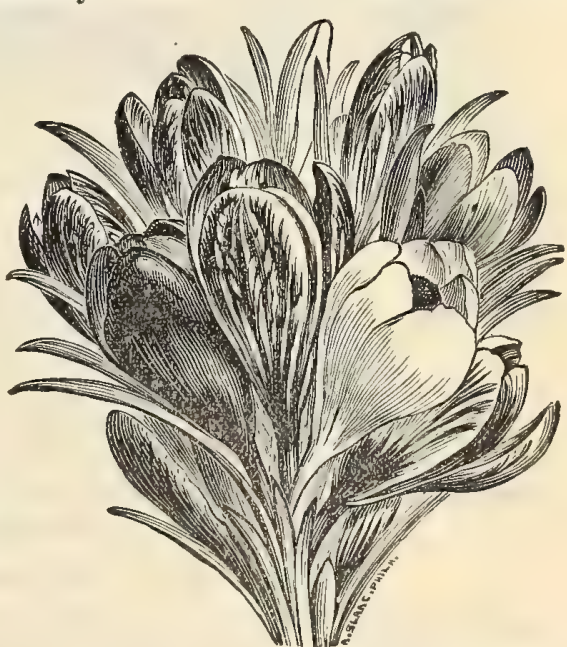

Mont Blanc, large pure white.

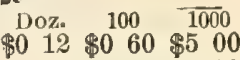
Sir Walter Scott, white, striped lilac......... $12: 60 \quad 500$

Mme. Mina, violet and white.............. $12 \quad 60500$

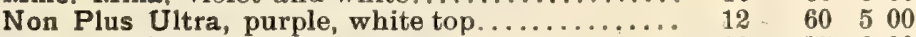

Yellow Prince, large golden yellow.......... $20 \quad 75 \quad 600$

Gloth of Gold and Cloth of Silver.............. $15 \quad 40 \quad 350$ 


\section{LILIES}

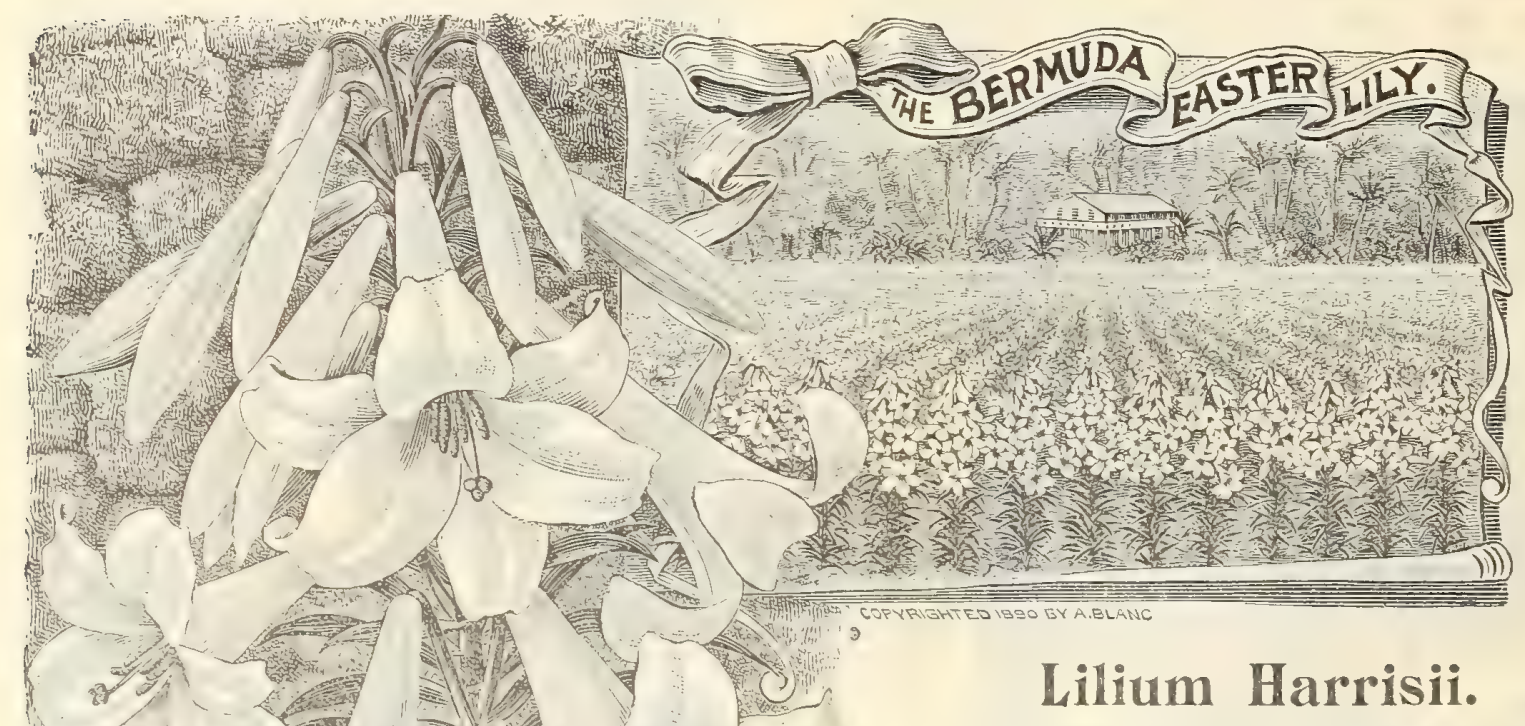

(Bermuda Easter L,ily.)

This beautiful Lily has become immensely popular on account of its free-blooming qualities: many thousands are now yearly forced for the New York market, where it has met with great favor. It is larger in size than the old Longiflorum, flowers pure white, richly fragrant and of good substance. For early forcing the bulbs should be started is September; these may be had in flower by the Christmas Holidays, and by successive plantings, up to December, they may be had in flower until spring.

Our stock of this Lily is of unsurpassed quality. The bulbs are sound, well cured and of good form; not cracked or misshapen.

There are numerous offerings of Lilium Harrisii on the market, which, to say the least, cannot be rouched for as reliable, as they are picked up here and there among small growers and in many instances are mixed and of general poor quality. Our entire stock was grown and packed under the personal supervision of our agent in Bermuda, and is uniformly first-class.

\section{...PRICES...}

First Size Bulbs. - $(5$ to $7 \mathrm{in.}$ in circumference). 10c. each; 75c. per doz.; $\$ 5.00$ per 100 . (Postage, $1 \mathrm{c}$. per bulb extra.) Each bulb should produce from 5 to 8 flowers.

Extra Size Bulbs. - 17 to 9 in. in circunference). 15c. each; $\$ 1.25$ per doz.; $\$ 8,00$ per 100 . (Postage $2 \mathrm{c}$. per bulb extra). This is the best size to grow as pot plants for decoration and equally as valuable for cutting. Each bulb produces from 8 to 12 flowers.

Monstrous Bulbs.-(9 to $12 \mathrm{in.} \mathrm{in} \mathrm{circumference).} \mathrm{25c.} \mathrm{each;} \$ 2.50$ per doz. (Postage 3c. per bulb extra). These monstrous bulbs make fine specimen pot plants for exhibition and decoration.

Six furnished at dozen rates, Twenty-five at too rates.

Lilium Auratum (The Golden-rayed Lily of Japan). We offer a fine stock of splendid sound bulbs of this peerless variety, the grandest of all the Lily family. 20c. each; $\$ 2.00$ per doz.

L. Candidum. The well known White Garden Lily, one of the best for outdoor decoration; is also largely used for forcing. 10c. each; $\$ 1.00$ per doz; $\$ 5.00$ per 100.
Lilium Humboldtii. Large, golden-yellow flowers spotted with purple. $40 \mathrm{c}$. each; $\$ 4.00$ per doz.

L. Leichtlinii, A charming Japanese Lily, of small, slender growth; the flowers are of a golden-yellow color thickly spotted with purple. 50c. each; $\$ 5.00$ per doz.

L. Longiflorum. The well known beautiful snow-white, fragrant Lily; fine for forcing and handsome in the garden. 15c. each; $\$ 1.50$ per doz. 


\section{LILIES-Continued.}

L. Pardalinum. Bright orange-scarlet, shaded to orange, freely spotted with maroon; six to twelve flowers on a stem; very large; height, 6 to 7 feet. 20c. each; $\$ 2.00$ per doz.

L. Pulchellum. Brilliant crimson, upright starlike leaves. 25c. each ; $\$ 2.50$ per doz.

L. Tenuifolium. One of the earliest to flower and most excellent for cutting; beautiful scarlet flowers. 25c. each; $\$ 2.50$ per doz.

L. Tigrinum. (Tiger Lily). Orange-salmon, spotted black. 10c. each; $\$ 1.00$ per doz.

L. Tigrinum Flore Pleno. (Double Tiger Lily.) This is a plant of stately habits growing from 4 to 6 feet high ; foliage dark green, very long, bearing an immense number of double bright orange-red flowers, spotted with black. 10c. each ; $\$ 1.00$ per doz.

\section{SPECIOSUM SORTS.}

Commonly known as L. Lancifolium, or Japan Lilies. All Lilies in this section can be relied on to give satisfaction to the buyer; they are easy growing, showy, distinct, very fragrant and beautiful; the different varieties probably form the most important group of any one species.

L. Speciosum Album. Pure white, very fragrant. 20 c. each ; $\$ 2.00$ per doz.

L. Speciosum Rubrum. Rose, spotted with crimson. $15 \mathrm{c}$. each; $\$ 1.50$ per doz.

L. Speciosum Roseum. White, spotted with rose, 15c. each ; $\$ 1.50$ per doz.

L. Album Præcox. Pure white, tinged with pink ; beautiful. $30 \mathrm{c}$. each; $\$ 3.00$ per doz.

L. Monstrosum Album and Rubrum. Distinct

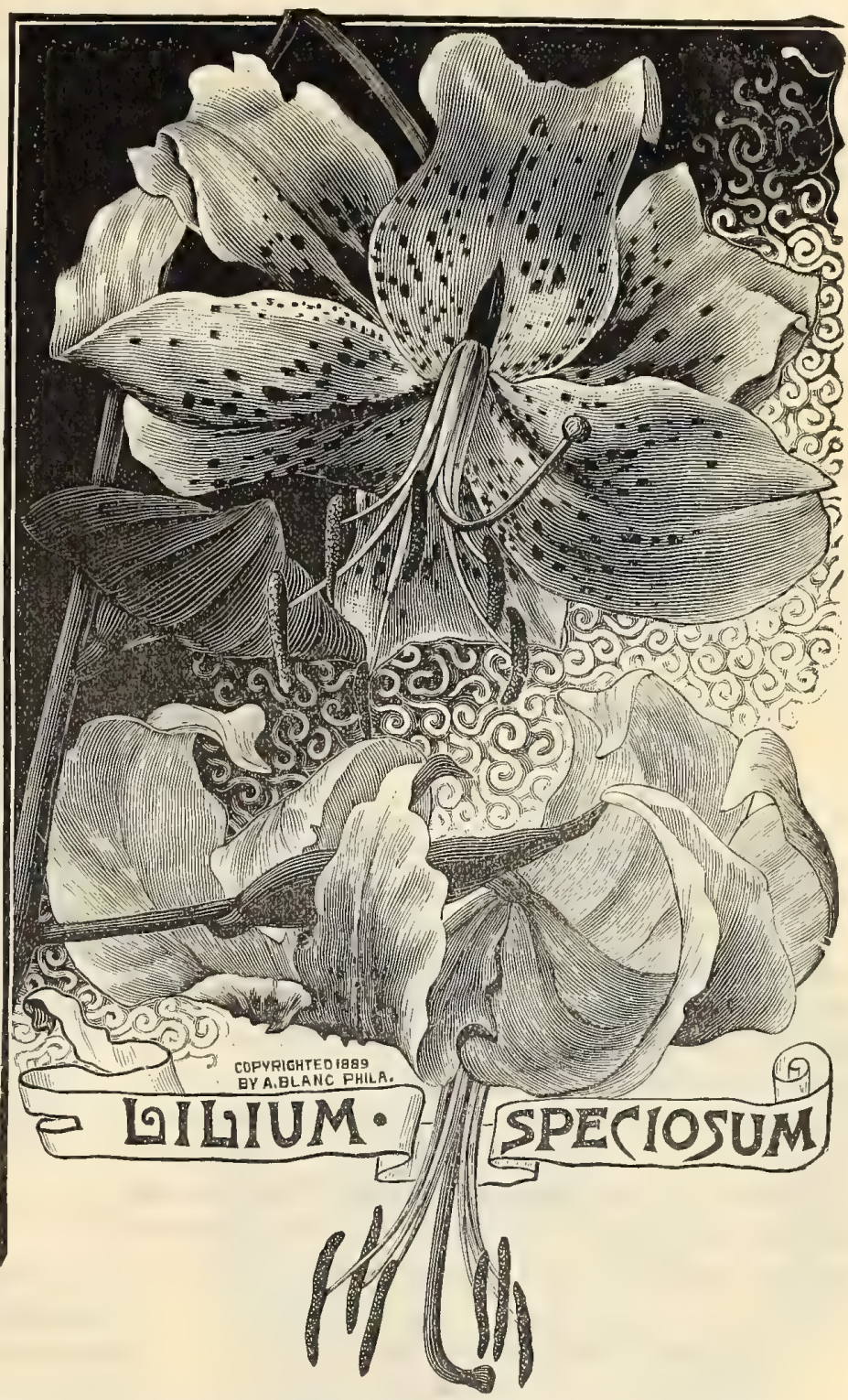

varieties, having broad flat stems, and immense clusters of pure white flowers, 20c. each; $\$ 2.00$ per doz.

S. Melpomene. Flowers very large and very abundant, of rich blood-crimson, heavily spotted. 25c. each; $\$ 2.50$ per doz.

When Lilies are ordered by mail, add 3 cents each; 30 cents per dozen to cover postage.

\section{CALLA LILIES-(Lily of the Nile.)}

By mail postpaid.

The Calla, or Richardia Ethiopica, is a well-known plant of easy culture, and in winter is one of our best window plants. To aid profuse blooming keep them dormant during the fall, and re-pot in November.
Richardia Æthiopica (White Calla).

First Size. 15c, each; $\$ 1.50$ per doz.

Extra large dormant roots, 25c. each; $\$ 2.50$ per doz. Richardia Alba Maculata. (Spotted Leaf Calla), 15c, each; $\$ 1.50$ per doz. 


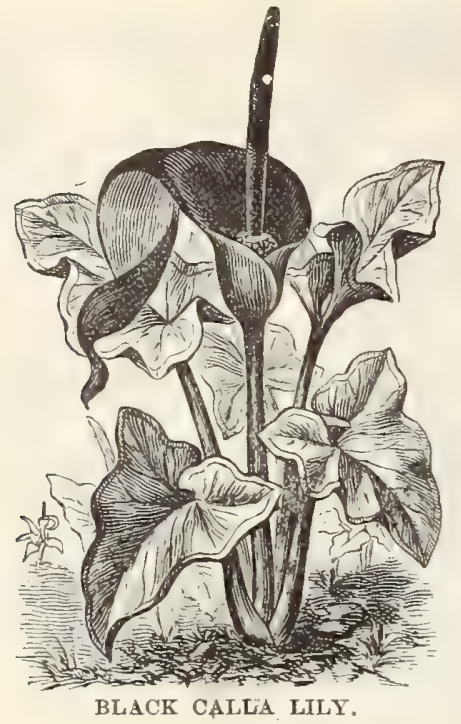

BLACK CALLA.

(Arum Sanctum.)

A magnificent and remarkable variety from the Holy Land. The plant produces one large flower the shape of a Calla, but from 14 to 18 inches long and 4 inches broad, and of a rich dark purple color and green underneath, somewhat wavy at the borders and curled at the smaller end. The spathe rising from the centre of the flower is about 10 inches long, velvet-like and quite black. It is raised on a slender but vigorous stalk of brown-red, shading to green at the upper end. The leaves are large and very wavy, of a rich green color, veined light green, and resemble exactly those of the Calla Ethiopica. Price, dry bulbs as collected, $15 \mathrm{c}$. ęach; $\$ 1.50$ per doz.

\section{LILY OF THE VALLEY. \\ Ready November 15.}

This charming little spring flower is a great favorite for forcing. It can be had in bloom throughout the entire winter by planting in succession. Pips are best for forcing. They should be kept in a cool place until three four weeks before wanted in flower, when they should be planted in pots or flats, sphagnum being used instead of soil. One or two nights' freezing will insure their blooming, the period of which can be hastened or retarded according to the temperature of the house.

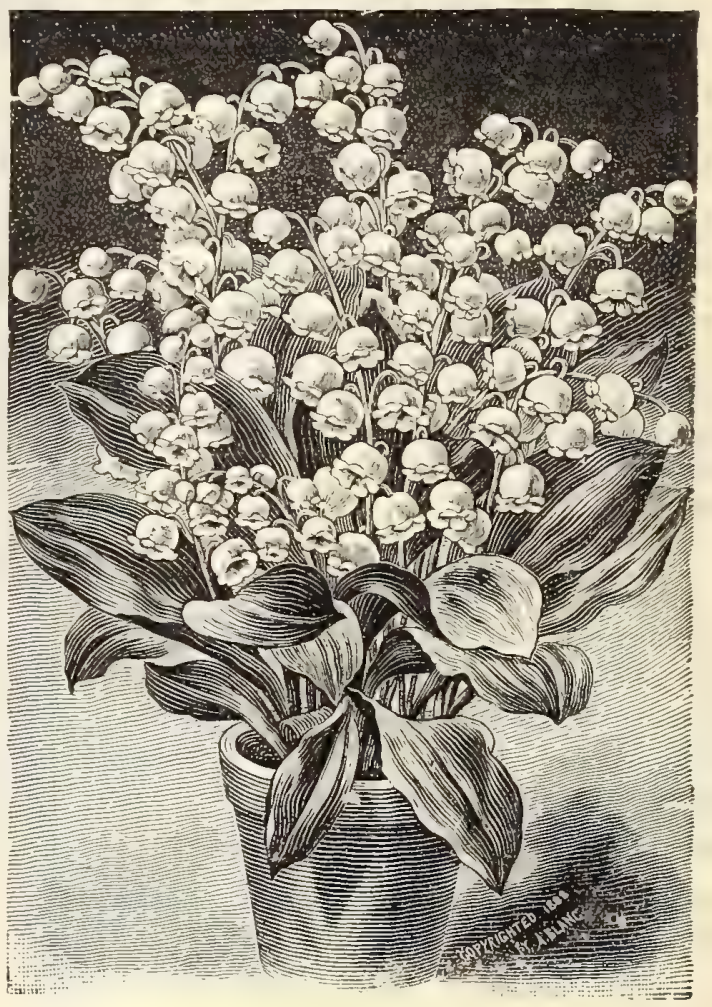

LILY OF THE VALLEY.

\section{SELEC'TED GERMAN PIPS.}

Three years old, for forcing and pot culture. 3 for 1 ćc.; 30c. per doz.; per bundle of 25 pips, $50 \mathrm{c}$; $\$ 1.75$ per $100 ; \$ 12$ per 1000 .

\section{LARGE CLUMPS.}

For open ground planting. 25c. each; $\$ 2.50$ per doz.; or by mail, 40c. each.

If Pips are ordered by mail, add ro cents per bundle or 25 cents per 100 to cover postage.

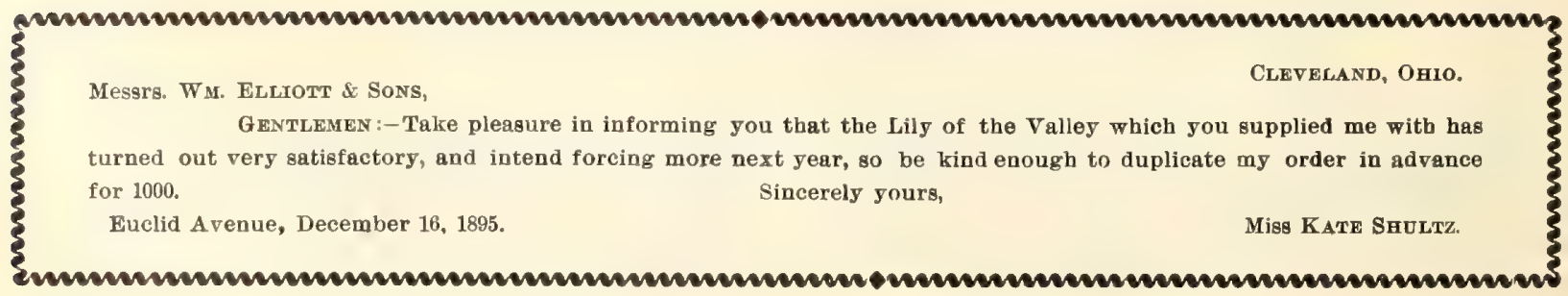




\title{
MISCELLANEOUS BULBS.
}

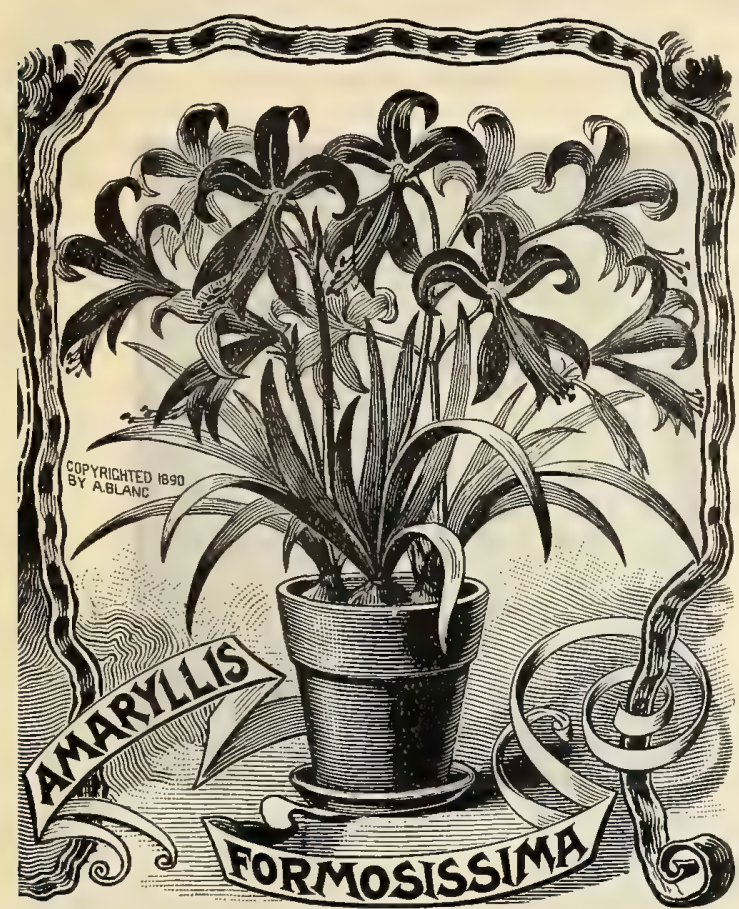

AMARYLLIS.

flowers, and is forced to a considerable extent for cutting for bouquets, etc.

Neapolitanum. Pure white, hardy. 5c. each; 20c. per doz. $\$ 1.00$ per 100 .

\section{ARUM DRACUNCULUS.}

\section{(Dragon Arum.)}

Curious hardy plant, with large, grotesque flowers of a dark maroon color, long smooth stem, beautifully mottled and handsome palm-like flowers. $10 \mathrm{c}$. each; $\$ 1.00$ per doz.

\author{
Postage 2 cents per bulb extra.
}

\section{ANEMONES.}

By mail postpaid.

The Anemone is unsurpassed among spring flowers for brilliancy of color and profusion and duration of blooming. The plant is very neat and compact in growth, with elegantly laciniated foliage, and produces in great abundance flowers of the most vivid hues of scarlet, blue, purple, self-colored and striped which have a splendid effect in beds or masses, while for cutting for bouquets or table decoration they are invaluable.

Each Doz, 100

ulgens. Brilliant crimson, with black center,

flowering very early in spring........... \$0 $05 \quad \$ 0 \quad 35 \$ 2 \quad 50$

Single Finest Mixed.................. $05 \quad 20100$

Double "6 $\quad \ldots \ldots \ldots \ldots \ldots \ldots \ldots \ldots \ldots, 05 \quad 25150$

These beautiful flowering bulbs thrive best in a light, loamy soil, and should be cultivated indoors. As pot plants for parlor and conservatory decoration during the winter, they are probably unsurpassed by any other genus.

Aulica Platypetala. Very large flowers, of a rich deep crimson, shaded with maroon; throat of a pale yellow tint. $\$ 1.25$ each.

Formosissima (Jacobean Lily). Scarlet. 15c. each; $\$ 1.75 \mathrm{doz}$. Belladona Major. 25c. each; $\$ 3.50$ per doz.

\section{ZEPHYRANTHES.}

"Zephyr Flowers" and "Flowers of the West Wind" are among our most beautiful dwarf bulbous plants, very effective for planting out in masses in May, flowering with great profusion during the summer. They are also most suitable for pot culture: 6 to 12 bulbs clustered in a 6 -inch pot in the autumn will give a fine display of bloom during the winter in the window garden or conservatory. 1 foot high.

Atamasco. White, suffused with flesh color. Three for $10 \mathrm{c}$.; 30c. per doz.; $\$ 2.00$ per 100 .

Candida. Pure snow-white large flowers. 5c. each; 50c. per doz.; $\$ 2.50$ per 100 .

Rosea. Large rose colored flowers. 5c. each; 50c. per doz.; $\$ 3.75$ per 100 .

Texanus. Bright yellow. 5c. each; 50c. per doz.; \$3.75, 100.

\section{ALliUM.}

By mail postpaid.

Decorative hardy spring flowering bulbs, suitable for rock work, etc. A. Neapolitanum has large heads of pure white

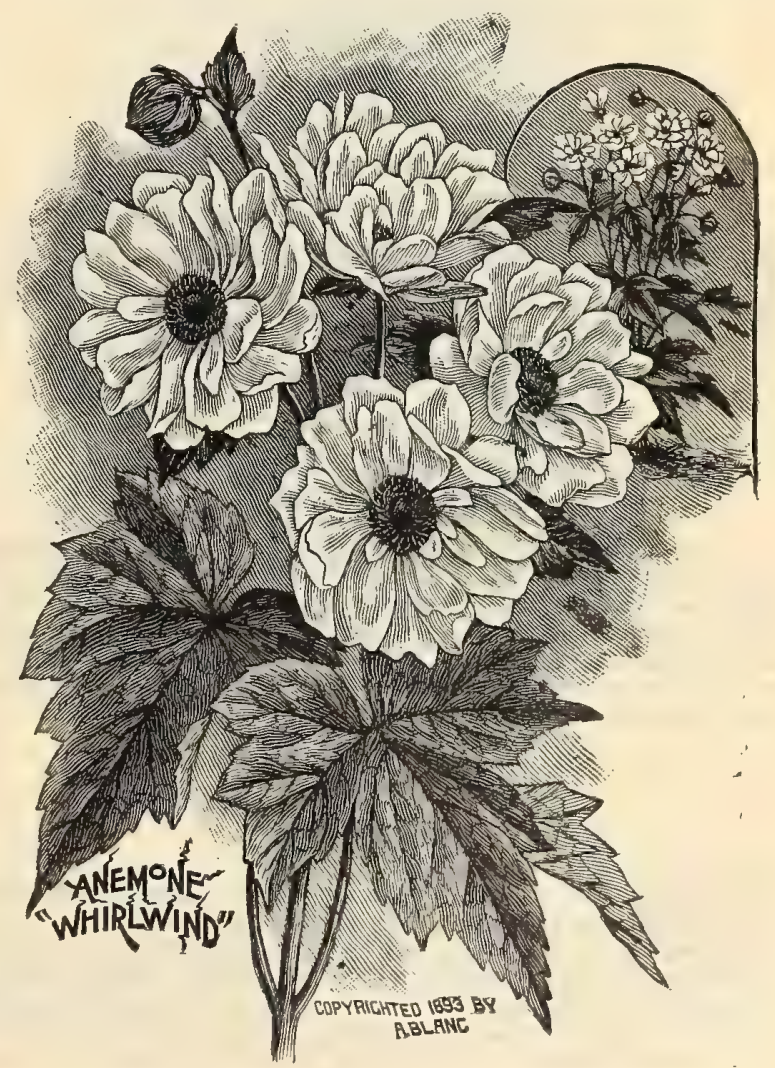




\section{CHIONODOXA LUCILIAE. (Glors of the Snow.)}

By mail Postpaid.

A most exquisite early spring flowering plant, thoroughly hardy, and will thrive well in any soil; it grows taller than Scilla Siberica, with flowers larger and more numerous, of a brilliant sky-blue color with white center. 5c. each; 20c. per doz; ; \$1,00 per 100 .

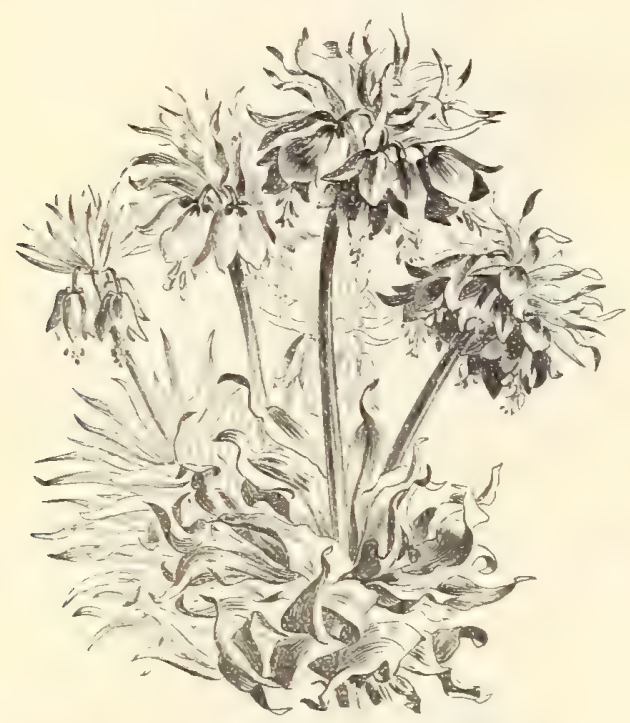

CROWN IMPERIALS.

\section{CROWN IMPERIALS.}

These are handsome border plants of stately growth, perfectly hardy, and produce their pendant, bell-shaped flowers in clusters. They will succeed well in free drained soils, and are very effective planted in clumps in shrubbery borders. Mixed varieties. 10c. each: $\$ 1.00$ per doz.

$$
\text { Add for postage } 3 \text { cents per bulb extra. }
$$

\section{COLCHICUM AUTUMNAL. (Atumu Flowering Crocus.)}

A pretty bulb with flowers resembling a Crocus, purple, white striped-treat as Crocus. The peculiarity of the plant is, that the flowers are produced late in autumn, and the leaves appear in the following spring, ripening the seed; a very interesting plant. The bulbs are large and should remain some time without being disturbed. 5c. each; $45 \mathrm{c}$. per doz.

$$
\text { By mail, add } 3 \text { cents per bulb. }
$$

\section{CYCLAMEN.}

7 Among the many charming plants which grace the flower house and sitting-room during the spring and winter months, few, if any, are so interestingly pretty and accommodating as the Cyclamen ; its neat, chaste, graceful little elegant flowers, varying from snow white to crimson, secure for it universal admiration, while the simplicity of its culture brings it within the reach of even those who can command no better accommodation than a sitting. room window.

Cyclamen Persicum, mixed. 10c. each; $\$ 1.00$ per doz. Giganteum, prize strain, 20c. each; $\$ 2.00$ per doz. Add for postage 10 cents per doz.

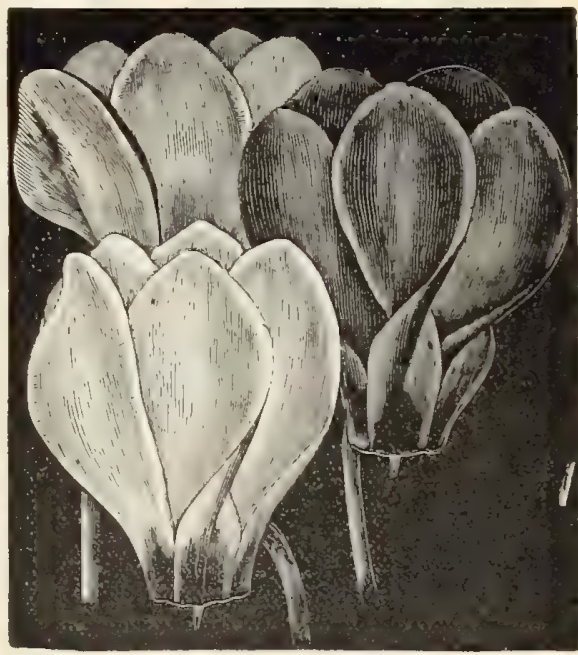

CYCLAMEN PERSICUM.

\section{ERANTHIS HYEMALIS. (winter Aconite.)}

One of the earliest harbingers of spring, when established forming sheets of large glistening-yellow flowers. It grows freely under deciduous trees, among grass or in fact in almost any position or soil. 5c, each; 25c. per doz. : $\$ 1.00$ per 100 .

By mail postpaid.

\section{GALANTHUS ELWESII. (The Giant Snowdrops.}

This is the largest and the earliest of all the snowdrops; flowers nearlv three times the ordinary size; is very desirable for forcing and slightly fragrant. 3c. each; 20c. per duz.; $\$ 1.25$ per 100 .

By mail postpaid.

\section{GLADIOLUS.}

Farly Flowering, Hardy varieties.

Among these are some of the most useful of the Gladiolus, flowering in May and June, when flowers are greatly in demand. For cutting purposes they are invaluable, as they will last in water for weeks after being cut; and as the flowers are smaller than autumn flowering sorts, they make up well for bouquets. They are hardier than most of the Gladiolus, but will not stand severe winters without covering. They are usually planted in October, and are covered on the approach of severe weather.

The Bride (Colvilli alba). Slender spikes, bearing 8 to 10 of the lovliest pure white flowers. One of the finest and most useful plants in cultivation, it is readily forced and can be had in bloom early in spring, and by successire planting, blooms can be had in August. 5c. each; 20c. per doz.; $\$ 1.00$ per 100 .

By mail postpaid at single and dozen rates. 


\section{FREESIA.}

By mail postpaid.

These are among the most beautiful of all Cape bulbs, possessing a peculiar grace of form, and their fragrance is most delightful, one pot of 5 or 6 bulbs being sufficient to perfumea whole house. As cut flowers they are extremely valuable, the unexpanded blooms opening in water fill the air with the most delicate perfume, and their endurance is really remarkable. They force very easily, and can be had in flower at Christmas, and continue in succession until June.

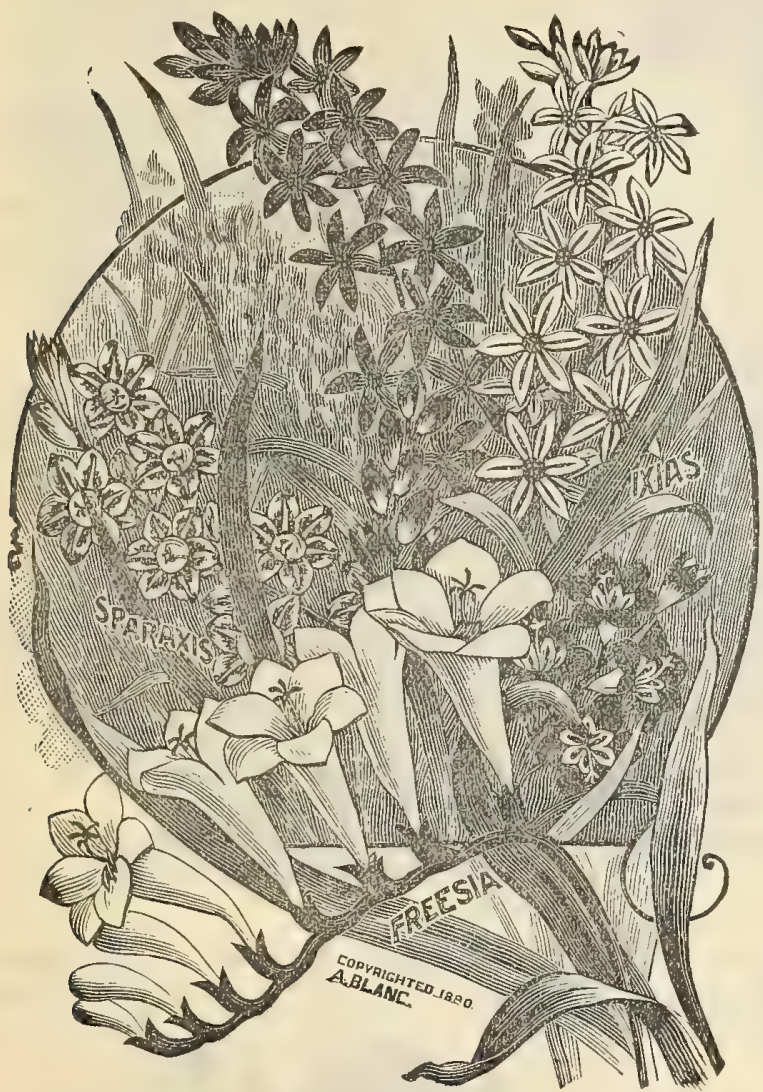

Refracta alba. Pure white, delightfully fragrant. 1st size, 15c. per doz.; 75c. per 100. Selected, 20c. per doz.; \$1.11 per 100. Mammoth, 35c. per doz.; $\$ 2.00$ per 100 .

Leichtlini. Pale yellow, fragrant. 6c. each; 60c. per doz.; $\$ 3.00$ per 100 .

\section{GLOXINIA.}

A superb genus of greenhouse bulbs, producing in great profusion beautiful flowers of the richest and most beautiful colors. They succeed best in sandy loam and peat, and require a moist heat. After blooming, dry off gradualls. let the bulb remain in the pot without water and keep in a warm place until it shows signs of starting again, $15 \mathrm{c}$. each; $\$ 1.50$ per doz.

By mail postpaid.

\section{HELLEBORUS NIGER. (The Christmas rose.)}

A beautiful, hardy herbaceous plant, flowering early in spring, and if grown in the house or in frames will bloom during the Christmis holidays. The flowers, 2 to 3 inches in diameter, range through all shades of white, red, rose and purple, and are produced in abundance. $25 \mathrm{c}$. each; $\$ 3.00$ per doz.

By mail, add 5 cents each to cover postage.

\section{ORNITHOGALUM ARABICUM.}

The Arabian variety of the "Star of Bethlehem" having large, pure white Howers, with a black center, borne in clusters on a stalk from 15 to 18 inches high. Hardy and showy plants, suitable for the open border. 5c. each; 40c. per doz.

By mail, 2 cents per bulb extra.

\section{LACHENALIAS.}

A beautiful class of spring flowering bulbs, adapted for greenhouse and ruom decoration. The spotted foliage and richly colored flowers are very attractive. Mixed colors. 15c. each; $\$ 1.75$ per dozen.

By mail postpaid.

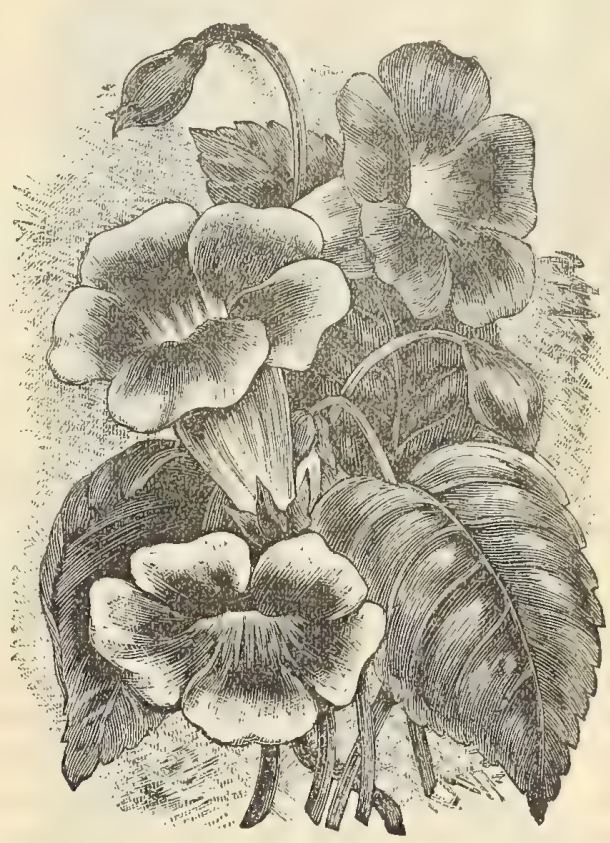

GLOXINIAS.

IXIAS.

These charming half-hardy bulbs are very ornamental for indoor culture, or planted outdoors in well drained and protected borders. They are graceful in growth; and the flowers are of the most brilliant, rich and varied hues, and when fully expanded make a charming and effective display. 5c, each; 20c. per doz.; $\$ 1.00$ per 100.

By mail postpaid. 


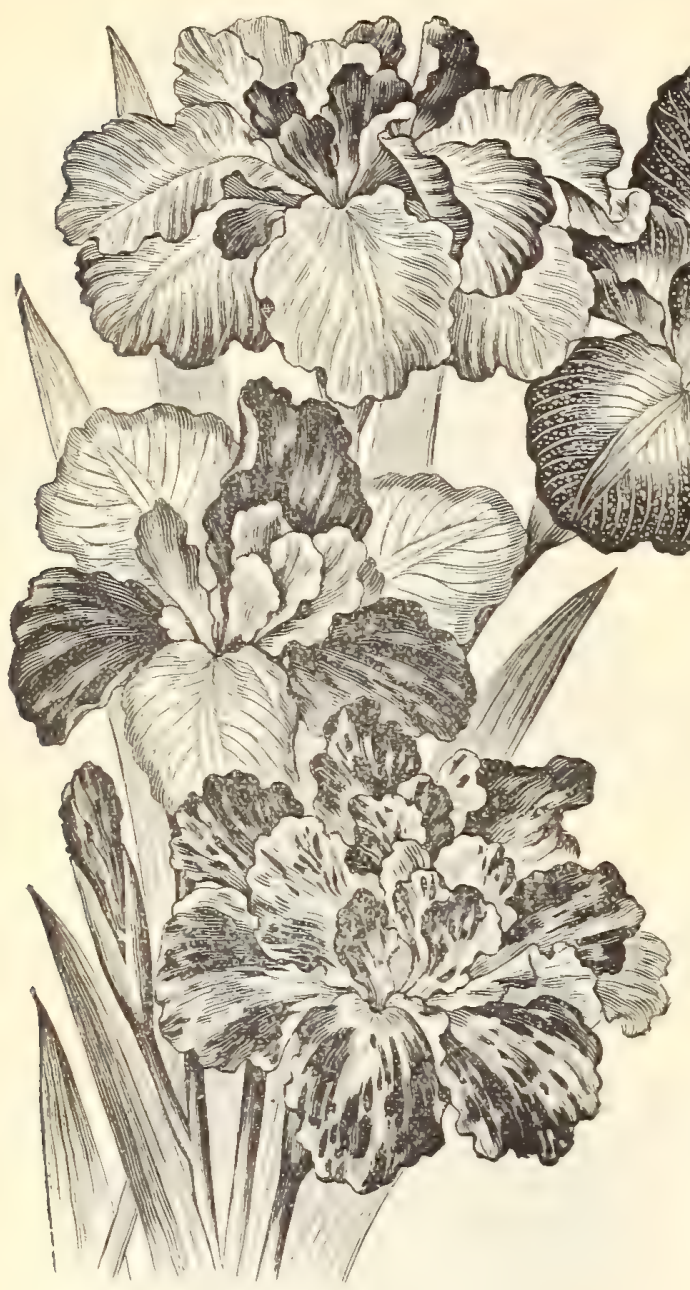

IRIS K EMPFERI.

\section{IRIS.}

Among the many forms of floral beauty which adorn the flower borders in June, the Iris has claims which entitle it to a more than ordinarily prominent position; the flowers are large and handsome, the color extremely rich and varied, while its cultivation is unusually simple, succeeding in any ordinary garden soil; when planted in clumps of three or more and allowed to remain undisturbed, it improves in beauty each succeeding year.

Iris Germanica. 6c. each; 50c. per doz.; $\$ 2.50$ per 100.

English. Finest mixed. 5c. each; 25c. per doz.; $\$ 1.50$ per 100 .

Spanish. Finest mixed colors. 5c. each; $15 \mathrm{c}$. per doz.; 75c. per 100.

Susiana. Blush tinted, netted with dark lines; a remarkable looking and exceedingly handsome flower. 20c. each; $\$ 2.00$, doz.

Tuberosa (Snake's Head Iris). Rich velvety black and green flowers. 12c. each; $\$ 1.00$ per doz.; $\$ 5.00$ per 100 .

Kæmpferi. Best named sorts mixed, strong clumps. 15c. each; $\$ 1.50$ per doz.

By mail postpaid.

\section{LEUCOJUM VERNUM.}

A beautiful early-blooming plant, resembling the Snowdrop, but of taller growth, flowers pure white, with a green spot on each of the petals. 5c. each; 30c. per doz.; $\$ 2.00$ per 100 .

By mail postpaid.

\section{OXALIS.}

Very pretty plants for pot culture, producing their bright-colored flowers in the greatest profusion, which form a fine contrast to their dark green foliage. They should be potted in light, porous soil, in September and October.

Alba. White. 5c. each; 25c. per doz.; \$1.75 per 100.

Boweii. Crimson. 5c. each; 25c. per doz. ; $\$ 1.75$ per 100 .

Lutea. Large yellow. 5c. each; 25c. per doz.; $\$ 1.50$ per 100.

Mixed Sorts. 5c. each; 20c. per doz.; $\$ 1.50$ per 100.

New Buttercup. 8c. each; 60c. per doz.; $\$ 4.00$ per 100.

$$
\text { By mail postpaid. }
$$

\section{RANUNCULUS.}

Exceedingly beautiful flowers, blooming in June, requiring deep, rich, loamy soil. Plant late in the autumn, about 2 inches deep, claws downward, and cover with striw and leaves before winter sets in, so as to protect from frost. They succeed well when cultivated in pots indoors, but should be kept in a cool, moist atmosphere.

Turban or Turkish. Very double and distinctly marked, great variety of color, comprising nearly every shade of white, crimson, yellow, purple, ete. 5c. each; 20c per doz.; $\$ 1,00$ per 100.

Persian. These are as beautiful as the Turkish, but quite distinct, producing smaller flowers and blooming later. 5c. each; 20c. doz,, $\$ 1.00,100$.

French. More vigorous in growth and larger flowered than the Persian or Turban. Very beautiful and varied. 5c. each; 20c. per doz; ; $\$ 1.00$ per 100 .

$$
\text { By mail postpaid. }
$$

\section{SCILLAS.}

Very beautiful early spring-flowering bulbs, of dwarf habit, from 6 to 8 inches in height, with drooping bell-shaped blossoms. They

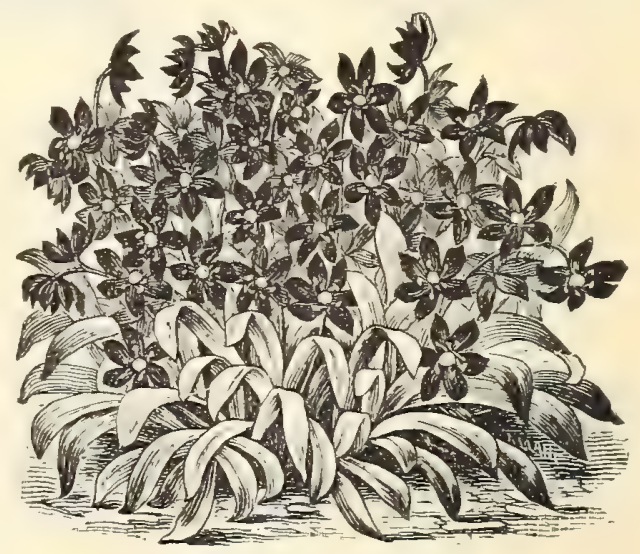

SCU,LA SIBERICA. 
are quite hardy, and easily cultivated, growing in any good soil; very suitable for growing in pots.

Amcena. Very fine blue. 5c. each; 20c. per doz; 75c. per 100.

Siberica. Blue, very early. 5c. each; 20c. per doz.; 75c. per 100.

Peruviana. Large pyramidal heads of bright blue flowers, excellent for pot culture. $15 \mathrm{c}$. each; $\$ 1.50$ per doz.

By mail postpaid.

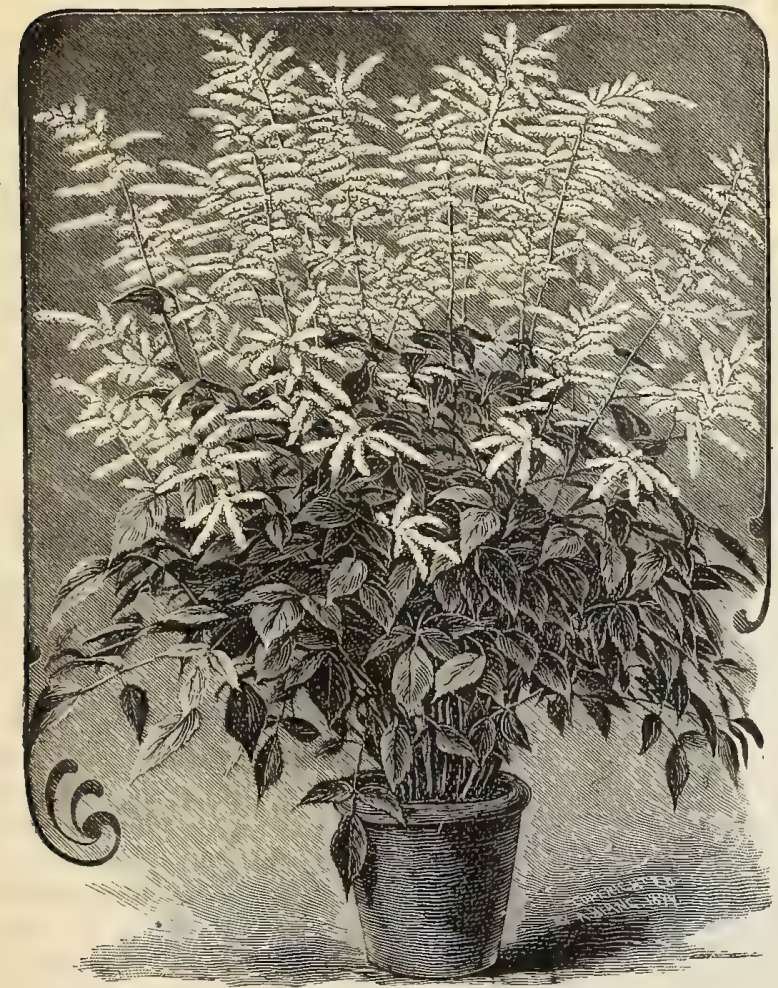

SPIRAEA ASTILBOIDES.

\section{SNOWDROPS.}

These beautiful little snow-white flowers, the earliest of all spring-flowering bulbs, are most suitable for planting on margins of beds or borders and on lawns, where a fine effect may be obtained by dibbling holes into the grass about a foot anart and 4 inches deep and planting a bulb in each hole. This method of planting will give a splendid effect in spring.

Single Flowering. 15c. per doz.; 85c. per $100 ; \$ 6.00$ per 1000 .

Double Flowering. 25c. per doz.; $\$ 1.75$ per $100 ; \$ 10.00$ per 1000. By mail postpaid.

\section{S P A R A X I S.}

These differ from the Ixias in their dwarf habit, time of flowering and brilliancy of coloring, ranging through the various shades of crimson, scarlet and white; mottled, striped and splashed in every conceivable manner. They require similar cultivation to the Ixia. $5 \mathrm{c}, \mathrm{each}^{2} 20 \mathrm{c}$. per doz; ; $\$ 1.00$ per 100 .

\section{S P I R A E A.}

Spiræa astilboides. Bronze leaved; pure white flowers. 15c. each; $\$ 1.50$ per doz.

Spiræa astilboides floribunda. (New.) Very large, pure white plumes. 20c. each; $\$ 2.00$ per doz.

Spirza Japonica. A remarkably elegant and graceful plant, with large, fealbery, pure white, sweet-scented flowers. Excellent for forcing and cutting. Fine large clumps for forcing or outdoor planting. $10 \mathrm{c}$. each; $\$ 1.00$ per doz; $\$ 5.00$ per 100 .

Grandiflora Compacta. Flowers larger than the above plants, more compact in growth. 15c. each; $\$ 1.50$ per doz.

By mail, ro cents per root extra.

\section{TUBEROSES.}

For Fall and Spring delivery.

Planted in succession from the end of December till June, a supply of blooms may be had from May to November. The bulbs should be potted firmly in rich loamy soil and kept in a temperature of not less than 60 degrees; water should not be given until the foliage appears, when it should be given freely.

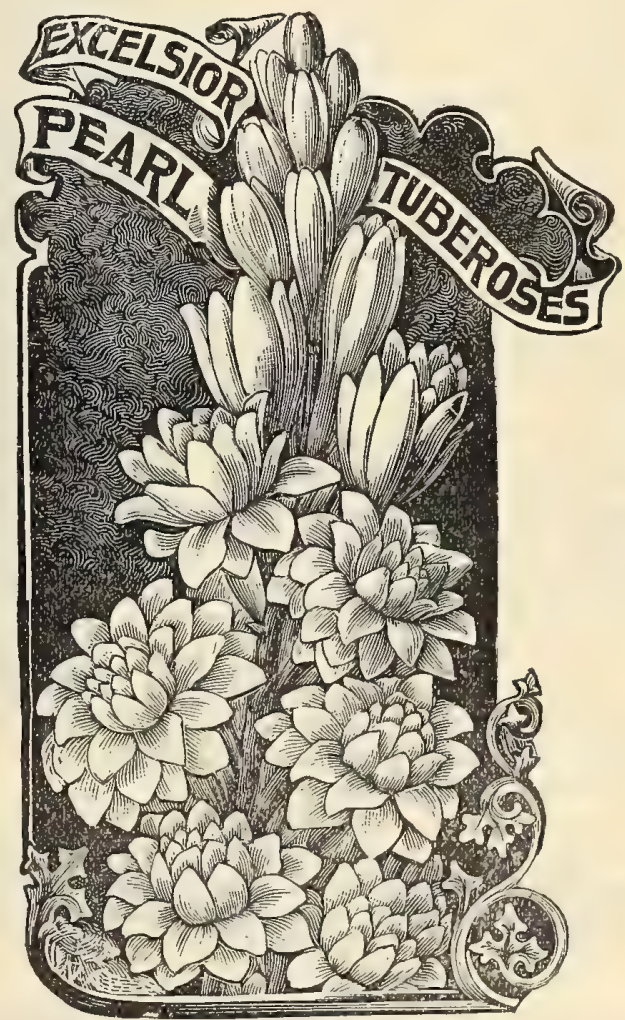

Dwarf Pearl. Largest size, 6c, each; 50c, per doz, ; $\$ 2.00$ per 100.

Excelsior Pearl. Extra fine large flowering bulbs. 6c. each; 50c. per doz.; $\$ 3.00$ per 100 .

By mail postpaid, at single and dozen rates. 


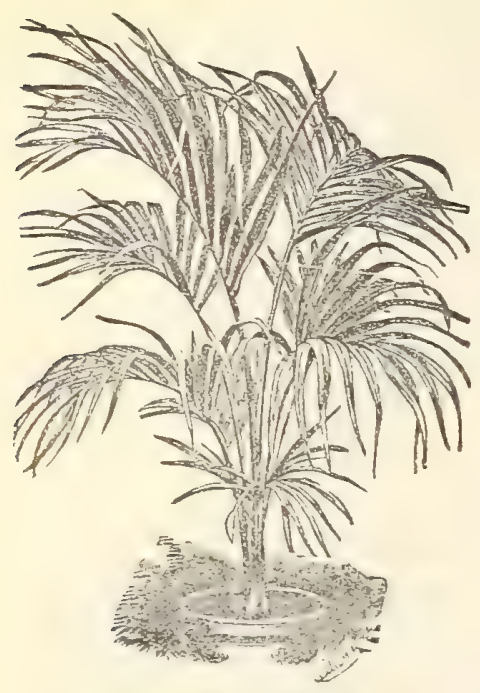

KENTIA BELMOREANA.

\section{ARECA LUTESCENS.}

This majestic Palm is without a peer for streng th and elegance combined. Its dark, glossy green leaves are gracefully curved on slender stems, and the entire foliage is gracefully disposed. The trunk and stems are a golden yellow, irregularly spotted with brouzy green, giving it a peculiar charm. Specimen plants, $\$ 5.00$ each.

\section{COCOS WEDDELIANA.}

This beautiful Palm is unquestionably the most elegant and graceful in cultivation. The finely cut leaves are recurved with exquisite grace. It is admirably adapted for the centers of jardinieres and fern dishes, as it retains its freshness for a long time, while for dinner-table decoration it is unexcelled. 10 to $12 \mathrm{ins}$, high, 75c. each; smaller plants, 35̃c. each.

\section{RUBBER PLANTS.}

We have a splendid stock of this useful and ornamental plant, which will flourish under the most adverse conditions. Price, $\$ 1.00$ each, 12 to 15 ins. high. Fine plants, 2 feet high, $\$ 1.75$ each.

\section{PANDANUS UTILIS.}

Pandanus is perhaps the most useful of our ornamental foliage plants. As a vase plant or single specimen in greenhouse or conservatory it cannot be surpassed. Price, fine plants, from 3 in. pots, $30 \mathrm{c}$. each; from 4 in. pots, 50c. each.

\section{Palm Seeds.}

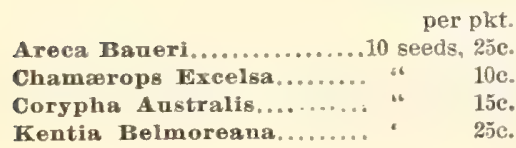

\section{PLANTS.}

\section{LATANIA BORBONiCA (Fan Palm.)}

This fine Palm is too well known to need any extended description; its strong constitution and other grand characteristics render it one of the most popular Palms

\section{KENTIA BELMOREANA.}

The Kentias are among the best of the Palm species for general cultivation, almost impregnable against diseases. The variety shown in the engraving is one of the best in its class, graceful habit, bright green foliage gractfully

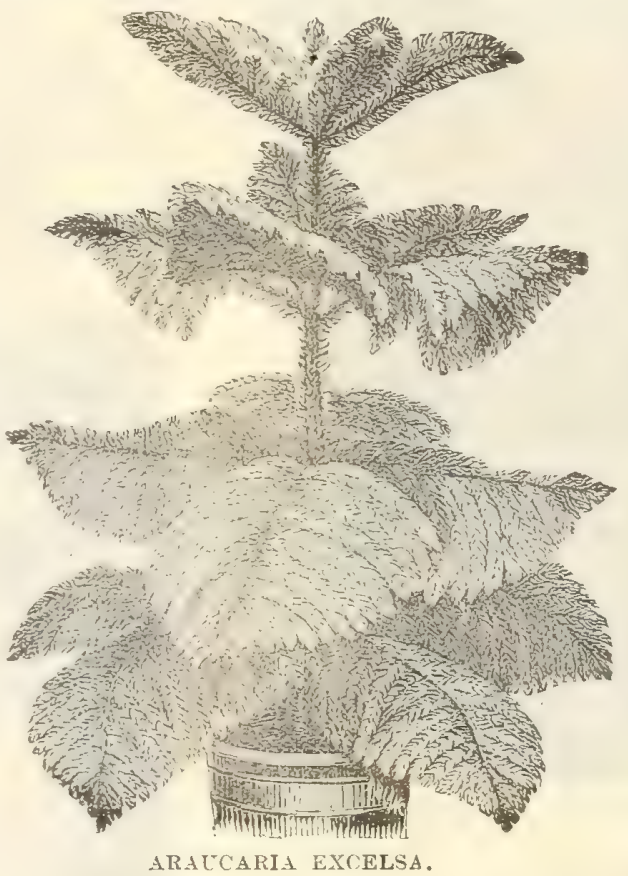
disposed; it scarcely has an equal. (See cut). Price, strong plants, 21/2 to 3 feet high, $\$ 3.00$ each.

\section{DRACAENA INDIVISA.}

Of all the plants in use for centers of vases, baskets, or for beds in the open ground, nothing is so valuable as this. From its graceful drooping habit it sometimes is called the "Fountain Plant." Price, 50c. and $\$ 1.00$ each, according to size.

\section{ARAUCARIA EXCELSA.}

Deep green, feathery foliage, arranged in whorls, rising one abore the other at regular distances; its symmetry of form, grace and beauty of foliage are unequaled in the vegetable kingdom. (See cut). Price, $\$ 2.00$ and up, according to size.

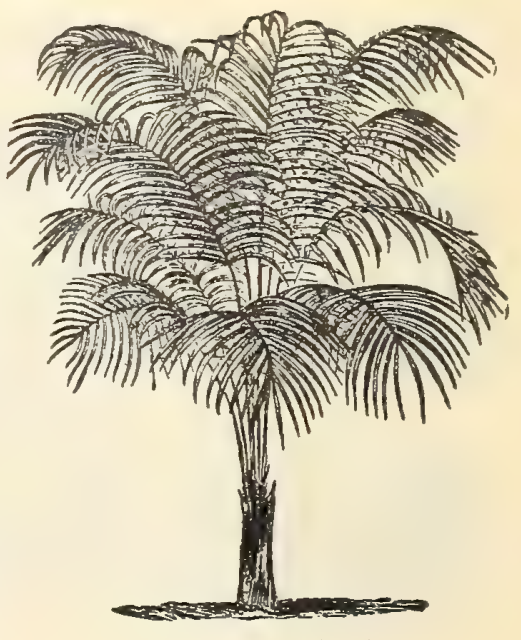

ARECA LUTESCENS. 


\section{HARDY ROSES FOR FALL PLANTING.}

Wo have on the way, which will be ready for delivery October 15, a splendid lot of Roses, which, if planted this fall ought to give a good crop of bloom next season. We offer only a comparatively small number of sorts, but these are all high-class and fine contrasting varieties.

\section{"Well Known Gen. Jacqueminot."}

The best, perhaps, of all Roses of the Hybrid Perpetual class. This grand old variety holds its own against all new-comers, and is undoubtedly the finest hardy Rose of its color.

La France. Flowers large and beautiful, either in the bud form or when expanded; peach-blossom color, shaded pink and silvery rose. It is freeblooming, every shoot forming a beautiful flower. In addition, it is hardy and most deliciously fragrant.

Capt. Christy. Delicate flesh color, deepening in shade toward the center; one of the most beautiful of the Rose family. The foliage is quite distinct. It is very free in flowering, and, taken in all, may be considered one of our best Roses.

Paul Neyron. Flowers 5 inches across ; color, lovely dark pink.

Alfred Colomb. Bright crimson, large full flowers.

Dinsmore. This grand dark red Rose is entirely hardy and ever-blooming, unquestionably the finest in its class or color. This Rose has been growing steadily in popularity.

Duke of Edinburgh. A splendid dark reddish crimson Rose. In form and fragrance it is unsurpassed. One of the most prolific bloomers, flowering freely in the fall.

Prairie Queen. A perfectly hardy Rose, and very prolific, covered with flowers, of satiny pink.

Clothilde Soupert. This is a grand Rose. The color is a French white, deepening to rosy blush in the center, exceeding in distinctness of shadings the well-known Malmaison. The form and substance of the flowers are so perfect that the hottest weather does not cause a deterioration of either, so that even in mid-summer a bouquet of splendid buds aud open flowers can be obtained from this fine variety.
Hippolyte Jamain. Bright rose, with carmine, striped white and light rose; unlike most others of this class.

Mme. Gabriel Luizet. Brilliant rose, grand variety ; is a "sport" from "La France," and inherits all the grand qualities which have made its parent the favorite it is. The color is a deep, rich rose.

Prince Camille de Rohan. Velvety crimson, very double, large petals.

Cheshunt Hybrid. Cherry carmine, free-blooming.

Hermosa. Bright pink, a grand bedding Rose, and hardy with slight protection.

Persian Yellow. Pure yellow, perfectly hardy and ever-blooming; a strong, vigorous grower. Worthy of a place in every collection.

Magna Charta. An exquisite shade of dark pink, deliciously fragrant and wonderfully free-blooming properties.

Anra de Diesbach (Gloire de Paris). Rich carmine, Rosa Rugosa. (Japanese Rose). Rosy crimson flowers, followed by a large, handsome, scarlet seed pods; one of the finest hardy shrubs in cultivation.

Price, for any of the above, 25 cents each, $\$ 2.75$ per doz.

\section{Hardy Climbing Roses for Outdoor Planting.}

Mme. Plantier. Pure white; a fine climbing Rose.

Baltimore Belle. Magenta red; a vigorous grower and prolitic bloomer.

Gem of the Prairies. Large double flowers of a deep rosy crimson and very fragrant.

25 cents each, set of 3 for 60 cents. 


\section{Hardy Flowering Shrubs.}

Ready October $15^{t h}$.

Hydrangea Paniculata Grandiflora. One of the finest hardy shrubs in cultivation; the flowers are formed in large white panicles of trusses, nine inches in length. The shrub grows to a beight and breadth of five or seven feet, and as the flowers slightly droop, few plants have the grace and beauty presented by this magnificent shrub. Used largely in cemeteries. $15 \mathrm{c}$. $25 \mathrm{c}$. and $40 \mathrm{c}$, each, according to size $; \$ 1.50, \$ 2.25$ and $\$ 4.50$ per doz. Althea, Double White. Double white flowers.

Althea, Double Red. Similar to the above, except color, which is red.

Berberry, Purple. A very ornamental shrub.

Calycanthus Floridus. Strawberry-scented shrub.

Corchorus Japonica. Double yellow flowers.

Corchorus Jap. Alba. Similar to above; white flowers.

Corchorus Jap. Var. Foliage prettily variegated.

Cornus Floridus. (Dogwood.) White flowers.

Cydonia Japonica. (Japan Quince.) Pink flowers.

Deutzia Crenata. White flowers, tinged pink.

Deutzia Gracilis. Low-growing, pure white; fine for cemeteries. Forsythia Viridissima. Yellow; blooms very eariy.

Lllac. The well-known purple-flowering variety.

PRIVET. (California.) Unsurpassed for hedges; upright, symmetrical growth, easily kept in shape; follage dark waxy green: fragrant $w$ hite flowers. It is most valuable as a single specimen or for massing in shrubberies. We bave a grand stock to offer. Price, 21/6 to $3 \mathrm{ft}$. high, 25c. each, $\$ 2.00$ per doz. $\$ 10.00$ per 100 .

Philadeiphus Coronarius, The popular Syringa or Mock Orange. White flowers; very fragrant.

Rhodotypus Kerrioides. A very pretty shrub, with pure white flowers.

Styrax Japonica. A rare shrub; white flowers.

Splraes, Douglassil, Superba, Thunbergii, Prunifolia, Van Houtteii. All flne sorts.

Weigelas, Rosea, Candida, Variegata.

Viburnum Opulus. (Snowball.) Large drooping white flowers. noted. Price for any of the above shrubs, 80 cents each, except wher

\section{Violet Marie Louise.}

The well-known double light purple variety. We offer strong. healthy plants, so that any amateur will have no diffoulty in growing them. Thousands of this peerless variety are grown for the flowers alone to supply the cut-flower markets of the country during the winter season. Price, large plants, 30c. each, $\$ 3.00$ per doz. Young plants, $10 \mathrm{c}$. each, $\$ 1.00$ per doz., $\$ 6.00$ per 100 .

\section{Hardy Climbing Vines.}

Ready October 5 th.

\section{(Sometimes called "Boston Iry" and "Japan Ivy.")}

No picture can portray the beauty of this grand climbing plant. In the summer the foliage is a rich shade of yreen, but in the fall it assumes the most gorgeous tints of scarlet, crimson and orange, so dazzling as to be seen a great distance. (Plants now ready.) ist size, pot-grown, 2 to 3 feet, 50c. each, $\$ 4.50$ per doz.; 2 d size, pot-grown, 1 to 2 feet, 25 c. each, $\$ 2.25$ per doz.

Aristolochia Sipho. (Dutchman's Pipe.) Large, showy, light green foliage; flowers long and pipe-shaped, hence the name. 50 c. each, $\$ 4.50$ per doz.

Clematis Paniculata. One of the most beautiful of our hardyflowering vines. The flowers are pure white. These clusters are borne on long slender stems. The fragrance is delicious. resembling the English hawthorn blossoms, and is so subtile and penetrating that a large plant in bloom will fill the air with fragrance. It begins to bloom late in August or early in September, at a time when most other bardy climbers are out of blcom, an inestimable advantage. It is a strong, rapid grower, blcom, an inestimable advantage. It is a strong, rapid grower,
quickly reaching a height of from 15 to 20 feet, and spreading out
when trained to wires or strings. It is perfectly hardy in all when trained to wires or strings. It is perfectly hardy in all in our opinion, the most valuable among hardy climbing vines. Price, 20c. each, $\$ 2.00$ per doz.

Clematis Jackmanii. The best known and most valued variety of this popular family. A perfect mass of bloom when in full flower. Color, dark, rich, royal purple. Ist size, 50c. each, $\$ 5.50$ per doz.

Clematis Henryii. A pure, white, large-flowering variety, of fine form, and recognized as by far the finest of the single white sorts. It is a much stronger grower than most of the other varieties, and is entirely hardy. Excellent for cemeteries, or wherever a hardy climber is desired. Large, strong plants, $75 \mathrm{c}$. each, $\$ 7.50$ per doz.

Clematis Lucie Lemoine. This variety is distinct from the above in form, it being perfectly double, like a rosette. It is sweetly fragrant, and equally hardy and vigorous with the others. Price, lst size, large plants, $75 \mathrm{c}$. each; $\$ 7.50$ per doz.

\section{CLEMATIS， LARGE-FLOWERING, ASSORTED.}

In addition to those mentioned above, we can supply donble blue, single blue, lilac, lavender and many intermediate shades, all strong plants. Price, $75 \mathrm{c}$. each, $\$ 7.50$ per doz

\section{Foreign and Domestic Grape Vines for Vineries.}

We offer the finest collection of Foreign Grape Vines grown in the country. They are all good, strong and healthy canes, true to name

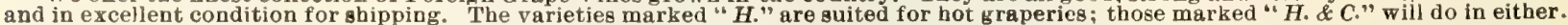

Muscat of Alexandria. Large Grape, of light golden color; the Gros Colman. Black. H. \& C.

most popular of the white kinds. $H_{*} \& C$.

Black Hamburg. Sweet and juicy; a well-known excellent sort. H. \& $\mathrm{C}$.

Barbarossa. Black. H.\&. C.
Buckland's Sweet Water. White. H.\& C.

Muscat Cannon Hall. Large White. $H$

Muscat Hamburg. Similar to black Hamburg, with Muscat flavor. H. \& $C$.

One year old Vines, \$1.00 each: extra strong, \$1.50 each; 2-years old, \$2.00 each. Extra strong fruiting Vines, \$3.00 each.

\section{HYACINTH GLASSES.}

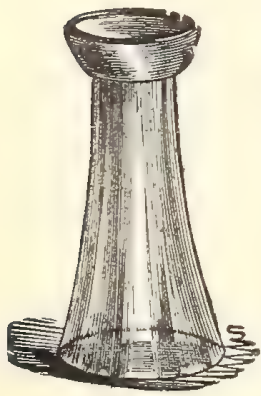

TALL.

Hyacinths grown in glasses of vater are charming ornaments for parlor windows, and the ease and success in flowering bulbs in this way add greatly to the popularity of not only Hyacintbs, but Polyanthus Narcissus, Amaryllis Formosissima and other bulbs, which can be grown in the same manner. Can be used for cut-flower vases when desired.

Patent Hyacinth Glass. This is in two parts; the inner contains the bulb and roots, and can be removed without injuring them, to refill with water. 25c. each, $\$ 2.50$ per doz

Tye's Shape Hyacinth Glass. An improved shape-not so easily tipped over-various colors. 15c. each, \$1.50 per doz.

Tall Hyacinth Glass. This is a favorite style; they come in various colors. 15c. each, $\$ 1.50$ per doz.

\section{CHINESE SACRED LILY BOWLS.}

As used by the Celestials for growing their famous "Joss Flower" in. The bulbs should be surrounded with pebbles to keep them from toppling over when in flower, and then water enough put into cover about one-half of the bulb; place them in a dark, cool closet for a couple of weeks to become rooted, and then bring into the light.

Glags Chinese Lily Bowl. 6 in. diameter, for 1 bulb, 25c.; 71/2 in. diameter, for 2 bulbs, 30c.; $81 / 2$

in. diameter, for 3 bulbs, 35c.

Hedgehog Crocus Pot. Price, $80 \mathrm{c}$.

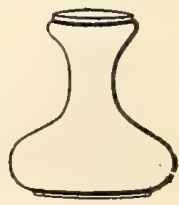

TYE'S SHAPE. 


\section{Flower Seeds for Fall and Winter Sowing.}

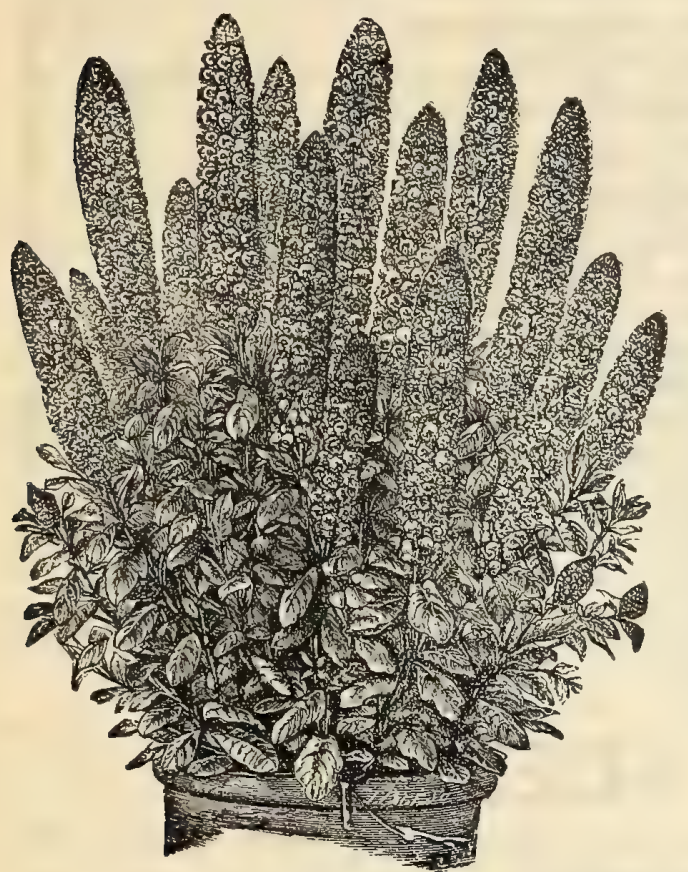

For Greenhouse or Indoor Culture.

Abutillon, finest mixed

per pkt.

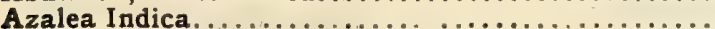

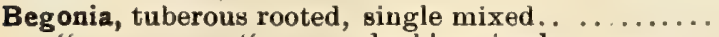

" " double mixed...........

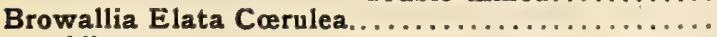

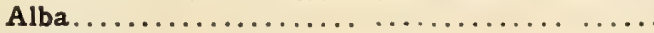
Roezlii.

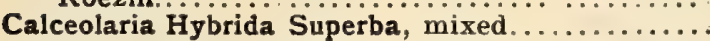
Rugosa (shrubby), mixed.

Carnation, finest monthly, mixed...............

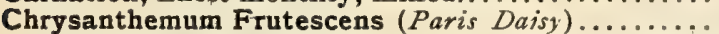

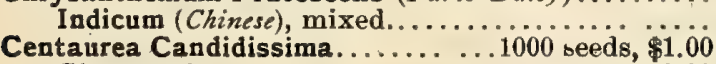
Clementei... ................ per oz., 2.00

Gymnocarpa.................... " 1.00

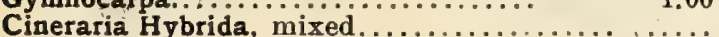

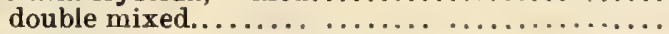

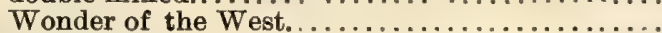

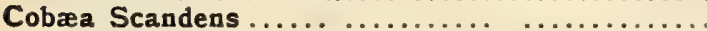

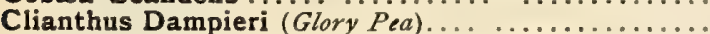

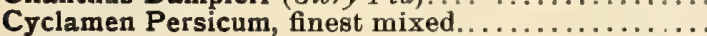

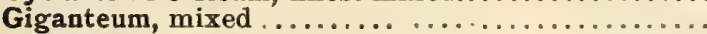

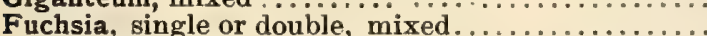

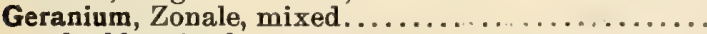

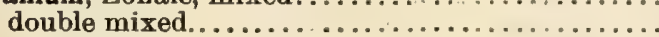

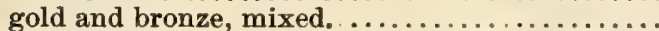
apple-scented. .

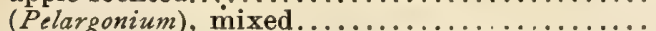

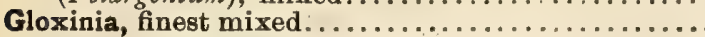

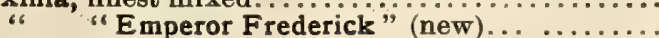

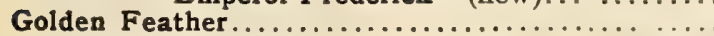

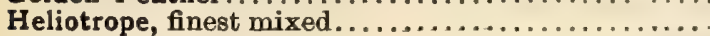

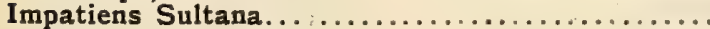

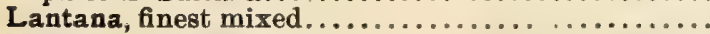

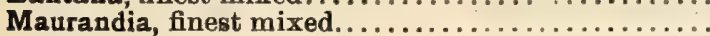

Mignonette, Elliott's Mammoth...... Machet.

\author{
(For Full List and Description, etc., see \\ Spring Catalogue.)
}

\section{ELLIOTT'S}

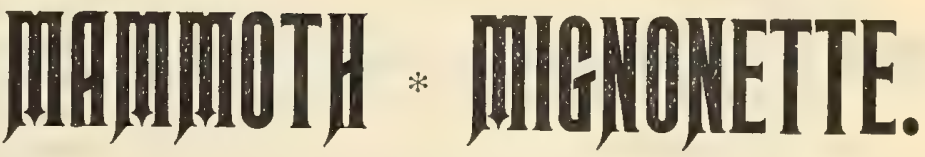

The exquisite fragrance of this modest flower has secured it a place in the heart of every lover of flowers. This strain which we offer is without doubt the largest flowered form that has yet been seen, and the finest Mignonette in cultivation. No garden is complete without it, and will be found equally valuable for growing under glass.

\section{Price, 10 cents per packet.}

\section{For Sowing Outdoors or in Frames.}

Alyssum Saxatile Compacta............... per pkt.

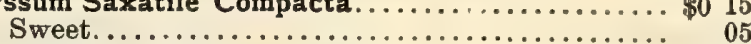

Ampelopsis Veitchii.....................

Antirrhinum Majus, fine mixed................. 05

Aquilegia, double mixed. .................. 10

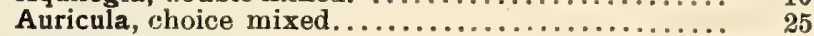

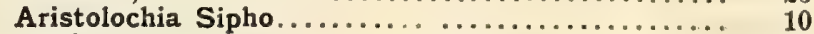

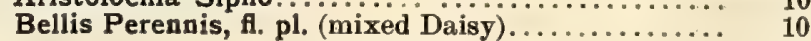

" " Alba..................... 10

“ " " Longfellow ................ 15

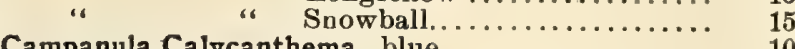

Media (Canterbury Bells)........................ 10

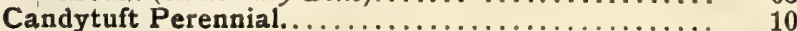

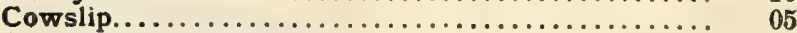

Delphinium Formosum......................... 05

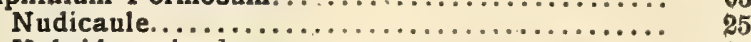

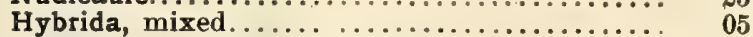

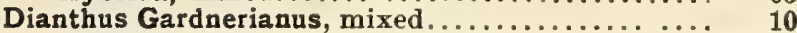

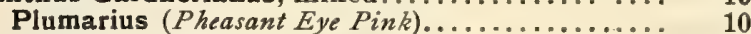

Scoticus, double.......... 50

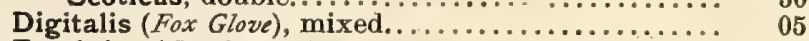

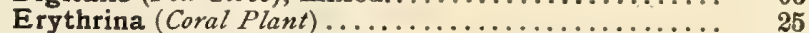

Gypsophila Paniculata................................ 05

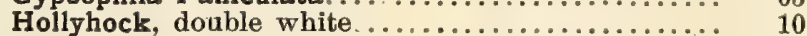

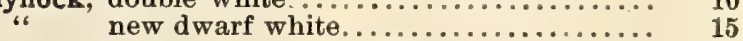

" $\quad$ nose.................................... 15

" $\quad$ yellow......................................... 10

" $\quad$ crimson................................... 10

" mixed............................. 10

Collection of eight varieties, large flowering,

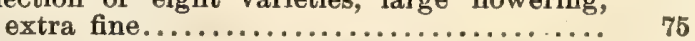

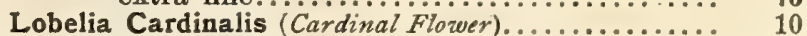

Lychnis Calcedonica......................... 05

Myosotis Alpestris, blue (Forget-me-not).............. 10

Dissitiflora............................ 10

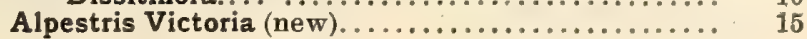




\section{FLOWER SEEDS FOR FALL AND WINTER SOWING-Continued.}

\section{For Greenhouse or Indoor Culture.}

Mimulus Tigrinus (Monkey Flower)............... per pkt. $\$ 0$

Moschatus (Musk Plant) $\ldots \ldots \ldots \ldots \ldots \ldots \ldots, 10$

Oxalis Rosea......................... 10

Petunia, finest mixed, single................ 25

double.......................... 50

Primula, Fringed Chinese, white............. 35

mixed............................. 35

double mixed........................ 75

Alba Magnifica........................ $\quad 50$

Obconica............................. 15

Smilax (Myrsiphyllum)................per oz。, 75c.

Stocks, ten weeks, large flowering, white.........

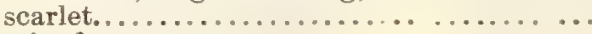

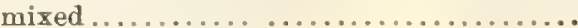

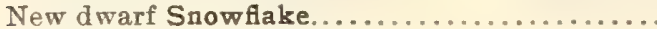

Boston Market, pure white......................

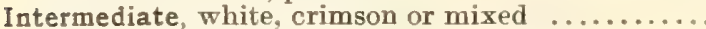

Verbena, extra choice mixed.....................

Vinca Rosea, rose.

Alba, white, red eye. red ............................... 35

\section{For Sowing Outdoors or in Frames.}

Pansy, Elliott's finest blended................. per pkt.

Giant Trimardeau........................ 15

Bugnot's, superb blotched, extra large flowering. $\quad 25$

Emperor William, blue..... . .............. 10

Yellow ........................... 10

Odier, or Five blotched................... $\quad 25$

Snow Queen, satiny white................. 10

Pentstemon, finest mixed....................... 10

Picotee Pink, finest mixed..................... 10

Potentilla, double mixed.......................... $\quad 25$

Polyanthus, finest mixed.................... 25

Pyrethrum Hybridum, fl. pl................... 25

Poppy Bracteatum......................... 10

Sweet Peas, mixed.....................per oz., 15c. 05

Sweet William, mixed...................... 05

double mixed ............................ 10

Viola Odorata (Sweet Violet)................... 10

Wallfower, single mixed.................... 05

double mixed ......................... $\quad 10$

Alower Seeds, annuals as well as biennials and perennials, may be sown in the open ground in fall, and if slightly protected during the winter, will produce strong and robust plants that will flower freely and early in the following spring.

\section{VEGETABLE SEEDS.}

Vegetable Seeds will be mailed free to any address at packet, ounce and $1 / 1 \mathrm{lb}$. rates. At pound rates, $10 \mathrm{cts}$. per pound must be added to cover postage.

\section{For Description of Varieties, see GENERAL SEED CATALOGUE.}

\section{Asparagus- olossal

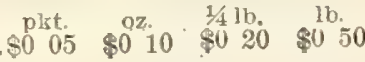

\section{Asparagus Roots-}

Colossal, $\$ 1.00$ per $100 ; \$ 7.00$ per 1000

Beans-

Early Red Valentine.

Early Mohawk.

Dwarf Black Wax

Golden Wax.

Refugee

Large White Kidney.

Beet-

Egyptian

Eclipse.

Early Blood Turnip

Bastian's Blood Turnip.

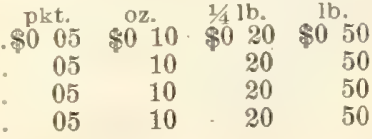

Cabbage-

Select Early Jersey Wakefield

Henderson's Early Summer.

Early Winningstadt.

Early York.

Fottler's Imp. Brunswick.

Excelsior Late Flat Dutch

All Seasons.

Red Dutch

Perfection Drumhead Savoy

10
10
05
05
05
05
10
05
05

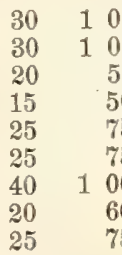

Carrot-

Early French Forcing......

Early Scarlet Horn........

Early Half Long Red(Stump Rooted)

Improved Long Orange...

$30 \quad 100$

$\begin{array}{lllll}05 & 10 & 30 & 1 & 00\end{array}$

100
Danver's Half Long.
Carrara Rock.

Early Snowball

Early half Paris, Nonparei

Algiers..................

Chicory-

Large Rooted.

Corn Salad or Fetticus-

Large seeded..............

\section{Cucumber-}

Nichol's Medium Green.... Improved Early White Spine

Boston Picking.

Green Prolific.

Short Green or: Gherkin ...

Egg Plant-

Black Pekin.............

Endive-

Moss Curled.

Broad Leaved Batavian

(Escarolle)..............

\section{Kale or Borecole-}

German Greens or Winter

"Sprouts"..............

Brown German Curled.....

Green Curled Scotch.......

Kohl Rabi-

Early White Vienna .......

Early Purple Vienna........

Leek-

\section{Large}

pkt.

25

10

15

05

15

$\$ 030$

$\$ 100$

05

10

25

75

05

05

05

05

05

10

10

05

05

05

10

10

10

10

10

\section{Cauliflower-}

Green Curled............... 
VEGE'AABE SEEUS-Continued.

Lettuce-

Early Curled Simpson...... po 05

Black Seeded Simpson........ 05

Tennis Ball (black seeded)... 05

Boston Market. ........... 05

Golden Stone Head........ 05

Salamander................. 05

Large White Summer...... 05

All the Year Round........ 05

Hardy Green Winter....... 05

Paris White Cos.......... 05

oz. $\quad 1 / 4 \mathrm{lb}$

$\$ 020 \quad \$ 050 \quad \$ 150$

$\begin{array}{llll}20 & 50 & 1 & 50\end{array}$

$20 \quad 50 \quad 150$

$20 \quad 50 \quad 150$

$\begin{array}{llll}25 & 60 & 2 & 00\end{array}$

$20 \quad 50 \quad 150$

$20 \quad 50 \quad 150$

$20 \quad 50 \quad 150$

$20-50 \quad 1511$

$20 \quad 50 \quad 150$

Melon-Musk-

Montreal Market........... 05

Nutmeg................ 05

Hackensack............. 05

Netted Gem.............. 05

Large Yellow Cantaloupe..

Peas-

Yorkshire Hero.

qt. $p k$.

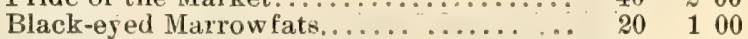

Pepper-

pkt. oz. 1/4 lb.

Golden Dawn............... \$0 $10 \quad \$ 0 \quad 30 \quad \$ 100$

Sweet Spanish............... $10 \quad 30 \quad 100$

Larga Bell or Bull Nose......... $10 \quad 3030$

Sweet Mountain or Mammoth...... $10 \quad 30 \quad 100$

Long Red Cayenne....... $10 \quad 30-100$

Chili..................... $10 \quad 30 \quad 100$

Potato-(Prices on application).

Pumpkin-

pkt. oz. $1 / 4 \mathrm{lb} . \quad 1 \mathrm{~b}$. Large Cheese............ \$0 $05 \quad \$ 0 \quad 10 \quad \$ 0 \quad 20 \quad \$ 060$ $\begin{array}{llllll}\text { Large Tours or Manmoth.. } & 05 & 10 & 30 & 1 & 00\end{array}$ Connecticut Field........ $05 \quad 10 \quad 15 \quad 35$

\section{Raddish-}

Long Scarlet Short Top. . . . 05050

Early Scarlet Turnip...... $05 \quad 05 \quad 10 \quad 25 \quad 60$

Early Deep Scarlet Turnip. . $\quad 05 \quad 10 \quad 25 \quad 60$

Earliest Erfurt Scarlet

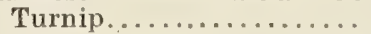

French Breakfast..........

Early White Turnip........

White Tipped Scarlet

for $\$ 1$. By mail. $25 \mathrm{c}$. $1 \mathrm{~b}$.

French, box of 3 lbs., $\$ 1.25$ per lb.

Nasturtium or Indian Cress-

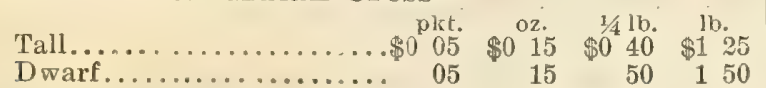

Okra or Gumbo-

New Dwarf Density..... $05 \quad 15 \quad 30 \quad 100$

Dwarf Green................ $05 \quad 10 \quad 25 \quad 75$

Long Green............. $05 \quad 10 \quad 25 \quad 75$

Onion-

Extra Early Red......... $05 \quad 20 \quad 60 \quad 200$

Wethersfield Large Red.... $05 \quad 20 \quad 50-150$

Yellow Globe Danvers....... $05 \quad 20 \quad 50 \quad 150$

$\begin{array}{llllll}\text { White Portugal, Silver Skin } & 05 & 30 & 75 & 3 & 00\end{array}$

Red Globe.............. $05 \quad 20 \quad 60 \quad 200$

Giant Rocca............. $05 \quad 20 \quad 50 \quad 150$

Early Queen................ $05 \quad 20 \quad 60 \quad 2 \quad 25$

Giant White Italian Tripoli. $05 \quad 0520 \quad 60 \quad 200$

Large Red Italian Tripoli... $\quad 05 \quad 20 \quad 60 \quad 200$

Parsnip-

Long Smooth or Hollow

Crown.............. $05 \quad 10 \quad 20 \quad 60$

Early Round.................. $05 \quad 10 \quad 20 \quad 60$

Parsley-

Double Curled........... $05 \quad 10 \quad 30 \quad 100$

Fern Leaved................ $05 \quad 10 \quad 30 \quad 100$

Plain................. $05 \quad 10 \quad 30 \quad 75$

Peas-(Price per bushel on application).

Elliott's Imp. Early Dexter........... $\$ 025 \quad \$ 150$

America's Wonder................... $30 \quad 200$

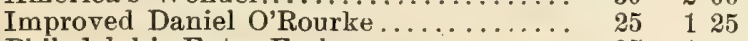

Philadelphia Extra Early.............. 25 125

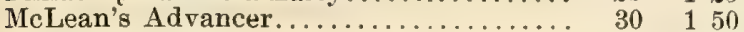

Bliss' Abundance...................... $40 \quad 200$

Bliss' Everbearing....................... $40 \quad 200$

Champion of England............... $25 \quad 150$

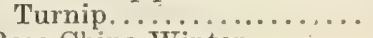

Rose China Winter........

Long Black Spanish........

Salsify, or Oyster Plant

Mammoth Sandwich Island.

Scorzonera, or Black Oyster

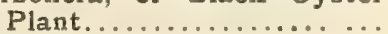

05

Spinach-

Bloomsdale Saroy Leaved..

Round Leaf. ..............

Large Round Leaf Viroflay.

Prickly...............

Squash-

Perfect Gem . .

Yellow Bush Scallop.

Bush Summer Crook Neck.

Boston Marrow..........

Hubbard................ 05

Winter Crook Neck....... 05

Tomato-

The Cardinal..............

Perfection................

Acme..................

Trophy, extra selected......

Golden Queen.

Turnip-

Extra Early Purple Top

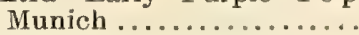
Red Top Strap Leaf........

Early White Strap Leaf.... White Egg ............. Purple Top White Globe...

Yellow Globe............

Golden Ball.................

Yellow Aberdeen..........

Ruta Baga Turnip-

Improved American Purple

Top..................

Skirving's Purple Top......

Long White French.......
$05 \quad 10 \quad 25$

$05-10 \quad 25$

$05 \quad 10 \quad 25$

05

05

05

10

15

10

10

30

10

20

60

200

05

05

05

10

15

3

35

35

35

60

75

60

100

75

150 0

(2)

10

10

10

10

10

10

30
25
25
25
25
25

100

75

75

75

75

250

250

250

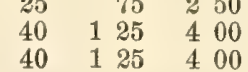

10

00

05

05

05

05

05

05

05

05

10
10
10
10
10
10
10
10

15
15
15
15
15
15
15
15

40
40
40
40
40
40
40
40

05
05
05

10
10
10

15
15
15

50

50 


\section{Elliott's Central Park Lawn Grass Seed.}

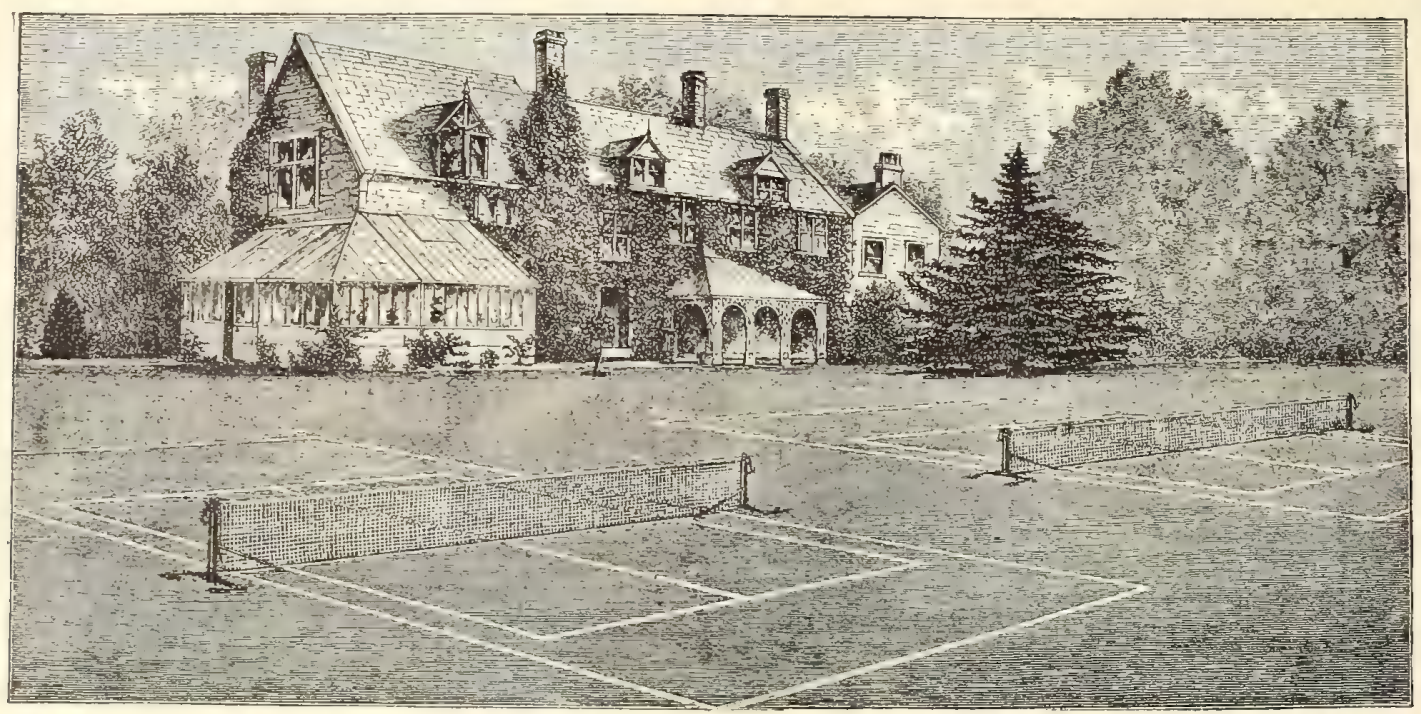

We are the original introducers of the above brand of Lawn Grass Seed, and with nearly fifty years' experience and a constantly increasing demand for the above mixture, we claim it to be the

CIEANEST AND REST LAWN SEED EVER OFFERED.

Price per quart, 20c.; peck, $\$ 1.25$; bushel, $\$ 4.50$.

\section{FRENCH OR EMERALD LAWN GRASS SEED-Second Quality.}

We put up this mixture to supply the demand for a cheaper grade than our Central Park brand. This mixture is equal to any offered at the price, but we do not recommend it where the best results are wanted.

Price per peck, $\$ 1.00$; bushel, $\$ 3.00$.

\section{ELLIOTT'S “TERRACE” MIXTURE.}

A special combination of grasses that produce strong spreading roots. Such varieties as will succeed in shallow soils and withstand drought. We recommend the above for sowing on terraces, enbankments and similar locations where it will produce and maintain a rich green turf throughout the season.

Price per quart, 30c.; peck, $\$ 1.75$; bushel, $\$ 6.00$.

\section{...The Preparation and Care of a Lawn...}

A good lawn is one of the most pleasing features of a rural home, and success in its formation depends much on the preparation of the ground. This should be done by draining if necessary and digging or plowing to the depth of 6 to 12 inches, according to the nature of the soil, applying at the same time a liberal quantity of well decomposed manure, bone dust, or pulverized sheep manure. We recommend the latter as being more lasting in its effects, not liable to burn the grass and free from weeds. Before sowing the seed the ground should be thoroughly cleaned and made perfectly level, and as the subsequent appearance of the lawn depends in a great measure on this part of the preparation, it is of the utmost importance it should be well done. The ground should be evenly raked, and the seed sown. April and September are the best months for sowing. The seed should be sown on a calm day, at the rate of four to five bushels to the acre. One quart is sufficient to sow an area of $15 \times 20$, or 300 square feet.

After the sowing has been accomplished, the ground should be again rolled, and as soon as the young plants have attained the height of 2 or 3 inches, the whole plot should be carefully gone over with a sharp scythe, and from the months of April to October it should be mown every ten days. Mowing machines are excellent after a comparatively close turf is established; but for the first six months after sowing the scythe should be used in preference to the machine. Frequent mowing and rolling are indispensable to maintain the turf in good order. By adopting these means a close green sward will be obtained in a short time.

The best LAWN FERTILIZER is Ram's Head Brand Sheep Manure. (See page 3I.) For other GRAssEs (See pages 55 and 56), General Catalogue. 


\section{Flliott's "Golf Mixture" Grass Seed.}

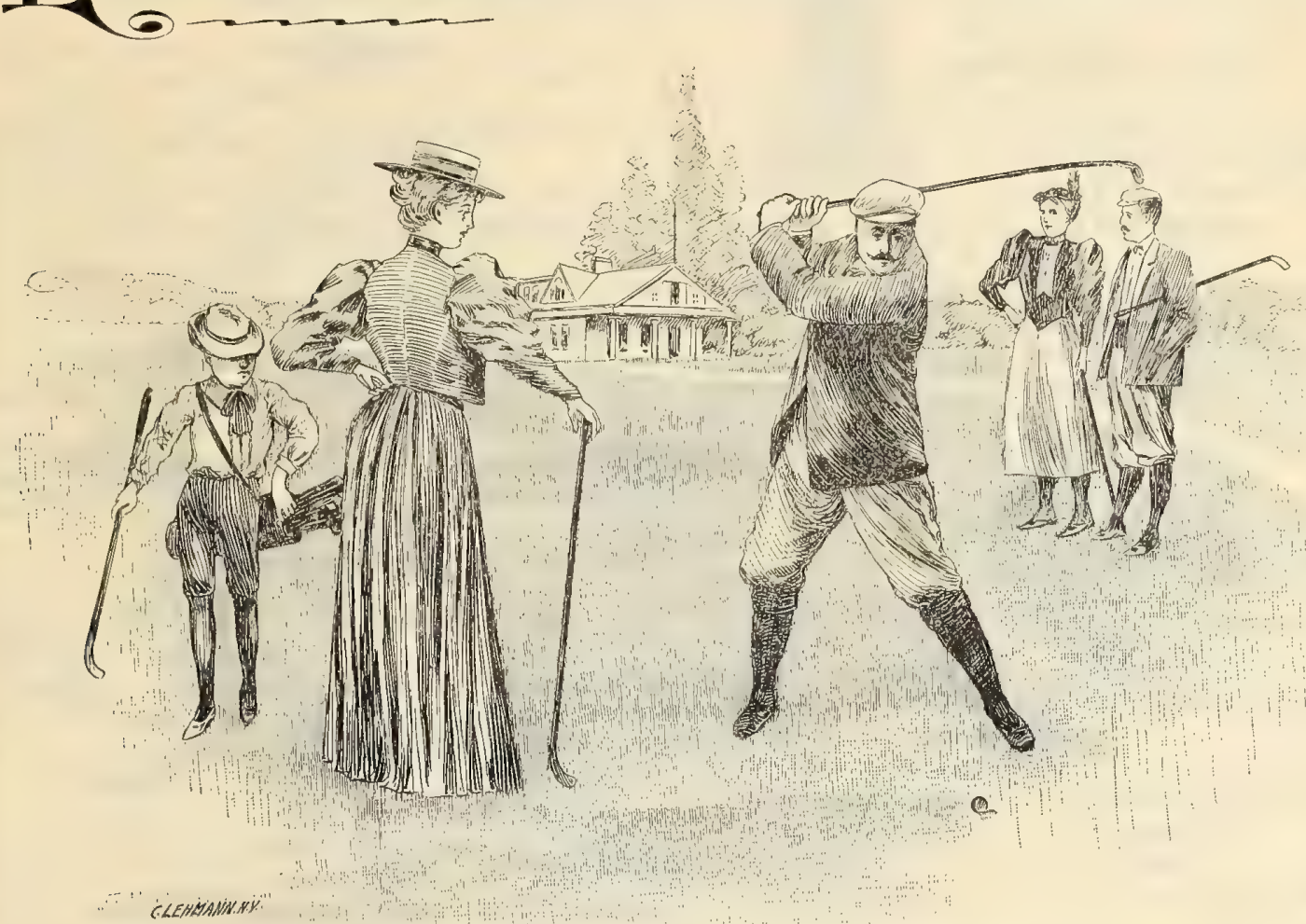

Owing to the popularity of Golf in this country and the number of Greens maintained for its support, there has been created a demand for a certain grass seed to grow on light soils and sandy situations, forming a compact sward, which is necessary where considerable walking is done; also to withstand a certain amount of drought during the summer, and maintain a velvety green appearance which is essential to a well kept Green. After numerous trials on our part, we have succeeded in filling the want; and to-day can offer you a mixture that cannot be duplicated elsewhere. Read what the president of the New Jersey Bowling Green Club has to say of it.

Messrs. WM. ElLiotr \& Sons,

54 and 56 Dey Street, City.

GENTLEMEN:-We have tried a number of grass seed mixtures for our Green each year, meeting with comparatively poor success, until your Golf Mixture was recommended; and without doubt it was all that you represented it to be; the members are more than pleased with the appearance of their Green.

Yours truly,

JOHN YOUNG, President.

Price, 25c. per qt.; \$1.25 per peck; $\$ 5.00$ per bushel. 


\section{Horticultural Tools and Requisites.}

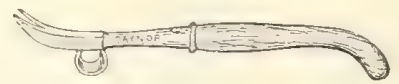

Daisy or Dock Lifter (English) . .

.$\$ 125$

Forks, Digging, 4 tine, $\$ 1.25 ; 5$ tine........... 150

Manure, 4 tine, $\$ 1.00 ; 5$ tine............ 125

extra heavy, 4 tine.............. 100

5 tine.............. 150

Fork, hand weeding, American, 25c.; English, 75c. and 100

Fruit-Picker, "The Boss," without pole.......... 75

Garden Line, linen twisted, 75 feet............ 50

"s braided, 75 feet............ 50

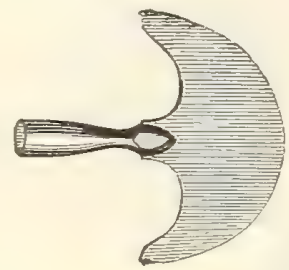

Grass Edging Knives (English), 8 in., $\$ 1.50 ; 9$ in ...\$1 65

" " " " $10 \mathrm{in} . . . \ldots \ldots \ldots . . .180$

" " " " " " handles extra..... 15

Grass Hooks (English), small................ 50

"6 6 " 6 mediun .............. 60

" " $"$ large................ 70

Hatchet, broad pruning................. 80

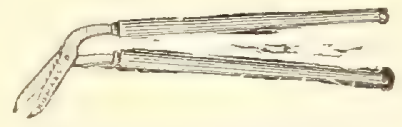

Hedge Shears (with notch, 25c. extra), 8 in........\$2 00

" " 9 in., $\$ 2.25 ; 10$ in.............2 50

Edging or Border Shears (English), (wheel 50c. extra),

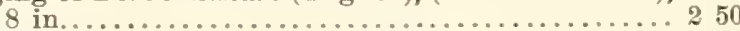

Edging or Border Shears (English), 9 in. $\$ 2.75 ; 10$ in. 300

Hoe, draw or field, 5 in., $40 c_{\text {. }} ; 6$ in ........... 45

" " 7 in., $50 \mathrm{c}, ; 8$ in................. 60

scuffle or push (English), 5 in., 55c.; 6 in...... 60

" " " " $" 7$ in., 65 c.; 8 in...... 70

" " " 69 in., $75 \mathrm{c} . ; 10$ in...... 80

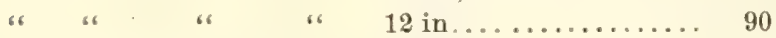

" " " " " 6 handles extra....... 15

" Prong or Potato Hook, flat tines. .......... 75

"6 Bayonet, 60c.; with handle ............. 75

. Crescent, 7 in., 50c.; 8 in............. 75

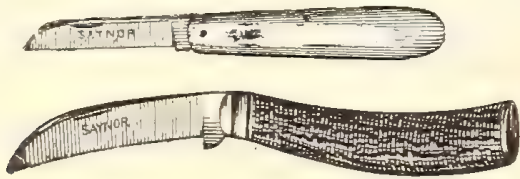

Knives, Budding and Pruning (Saynor's) $\$ 1.00$ to $\$ 175$ Knives, Amerisan ................50c, to 100

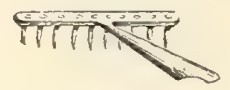

Rake, Garden, steel, 6 teeth, 35c.; 8 teeth........ \$0 40

" " " 10 " $50 \mathrm{c} ; 12$ " $5 . \ldots \ldots \ldots 60$

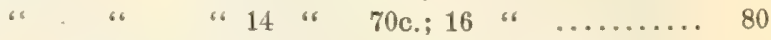

“Short Tooth, steel, 10 teeth, $50 \mathrm{c}$; 12 teeth ..... $\% 0$

" " " " 14 " $475 c_{.} ; 16$ " $16 \quad \ldots .85$

"Hay, wooden, 3 bow, 12 teeth............ 30

Lawn, wooden, 3 bow, 22 teeth..... ...... 50

" Davis' steel wire ................. 75

. or Daisy (English), 22 teeth ......... 350
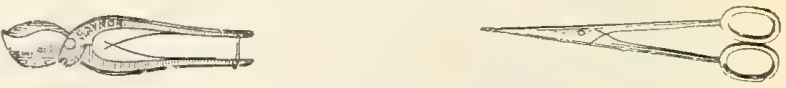

Scissors, Flower Gathering (English), 6 in.......\$1 25

" "6 " " 7 in....... 150

" Grape Thinning " " 6 in........ 100

.6 “ “ 7 in......... 120

“ Pruning (English) ...........\$1.00 to 175

“ Propagating................... 100

Reels for Garden Lines, wrought, large.......... 80 "6 "6 " galvanized... 200 Saws, Pruning, double.edged, 16 in............ 75

" " $"$ " 18 in........... 80

" " $"$ " 20 in............ 90

Shears, Lopping, (English), medium, $\$ 2.50$; large... . 300

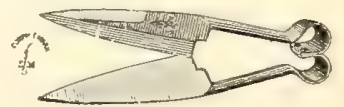

Shears, Sheep, (American) ..............\$0 75

(English), long blades .... \$1.00 and 125

WISS' HAND PRUNING SHEARS.

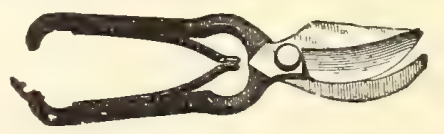

$71 / 4$ inches.......................... $\$ 150$

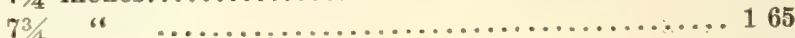

$81 / 4$ ،

$9 \quad$ “

\section{GERMAN PRUNING SHEARS.}

Malleable Iron-Steel Blades.

$71 / 2$ inches ........................... $\$ 100$

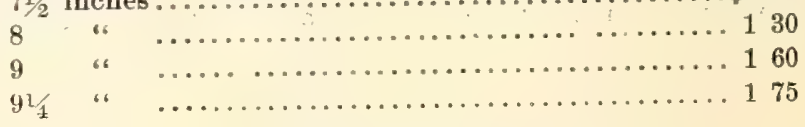

Various other Patterns

From..........\$1.00 to $\$ 4.00$ each. 


\section{BRASS GARDEN SYRINGES.}

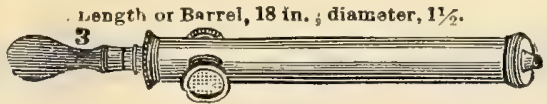

Syringes (American), No. 1, Ladies, 1 spray rose. . $\$ 250$ Syringes (American), No. 2, Ladies, 1 stream and

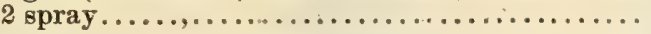

Syringes (American), No. 5, best conical valve,

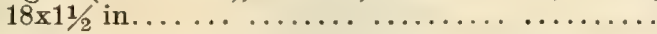

Syringes (American), No. 6, large size, 1 spray rose and angle joint, turning in all directions, for

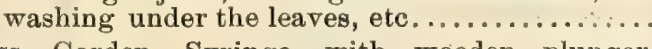

Brass Garden Syringe with wooden plunger, $17 \times 5 \frac{1}{4}$ in ............................ 125

\section{WATERING POTS-Galvanized.}
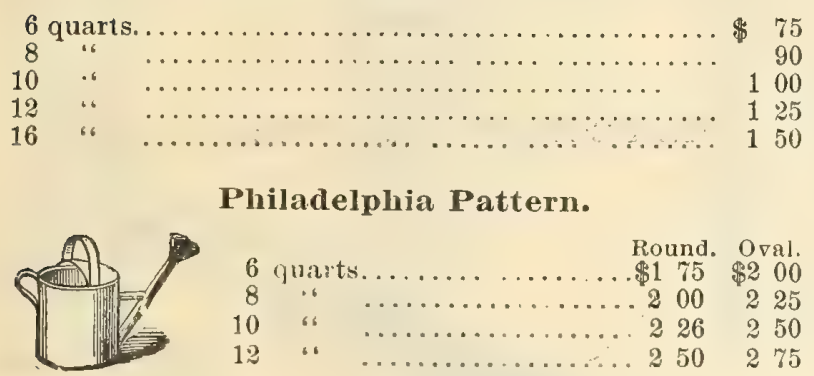

\section{ELASTIC PLANT SPRINKLERS.}

An indispensable article for window gardening, it being one of the best inventions for washing the foliage and sprinkling plants kept in the house during winter, and for washing and moistening cut flowers; and dampening clothes. $\$ 1.00$ each; by mail, $\$ 1,10$. Small size, $50 \mathrm{c}$. each ; by mail, $60 \mathrm{c}$.
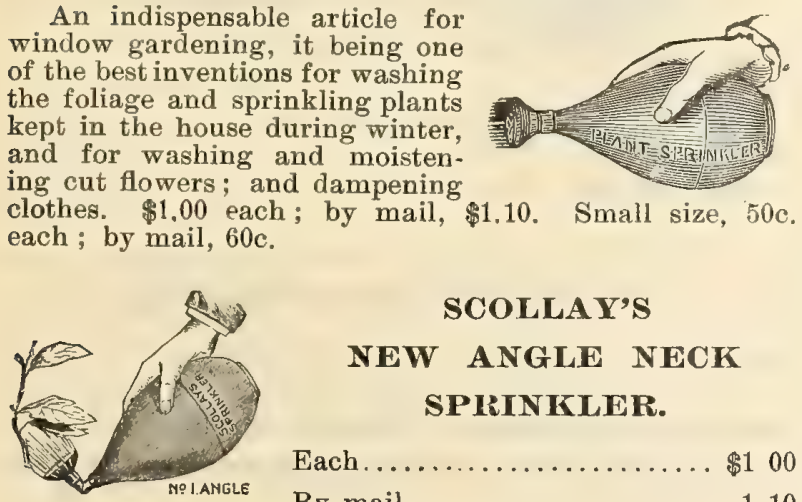

\section{SCOLLAY'S \\ NEW ANGLE NECK SPIRINKLER.}

Each ................. \$1 00 By mail.................. 110

\section{ARMORED RUBBER HOSE.}

The armor is a perfect protection from wear when being dragged on the ground, or over stone, cement or wood floors. It is more flexible than ordinary hose and cannot be "kinked."

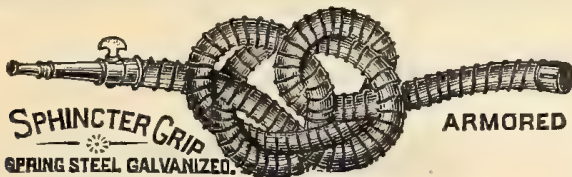

Per foot Armored Rubber Hose, 3/4 inch, 3-ply ......... \$0 18 Standard Ridgewood Maltese Cross

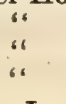

$$
\text { "6 }
$$

...............

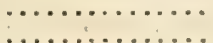

In 25 and $50 \mathrm{ft}$. lengths.

\section{THE EUREKA FUMIGATOR.}

This apparatus is of simple construction and not liable to get out of order. When once lit it is self-acting, and may be left in the house with perfect safety, as flaring or setting anything on fire is an impossibility, while all the material is completely consumed without waste, and giving off in a dense smoke, filling a house in a short time, thus ensuring the entire destruction of insect life. It can be used for fumigating greenhouses, pits, frames, hospitals, ships, poultry houses, etc.; for destroying vermin and purifying rooms. - Directions for use sent with each machine.

No. 1-Height, 12 in.; diameter at top, 5 in. For a house $10 \times 20$ feet. Holds half a peck of stems. . $\$ 150$

No. 2-Height, 16 in.; diameter at top, 7 in. For a house $12 \times 40$ feet. Holds one peck of stems..... 250

No. 3-Height, $20^{\circ}$ in.; diameter at top, 9 in. For a house $15 \times 100$ feet. Holds half bushel of stems. 300

No. 4-Height, 24 in.; diameter at top, 12 in. For a house $20 \times 100$ feet. Holds three-quarters bushel of stems........................... 375

\section{WATERS IMPROVED TREE PRUMER.}

The Best Tree Pruner in the Market.

$$
\text { Net }
$$
Prices. $4 \mathrm{ft} . \ldots \ldots \ldots \ldots \ldots$. each, $\$ 075$ $6 \mathrm{ft} \ldots \ldots \ldots \ldots$ " $\quad 85$

$8 \mathrm{ft}, \ldots \ldots \ldots \ldots \ldots \ldots \ldots \ldots$

$10 \mathrm{ft} . \ldots \ldots \ldots \ldots \ldots \ldots .6 \ldots$

Extra Blades........ " $\quad 20$

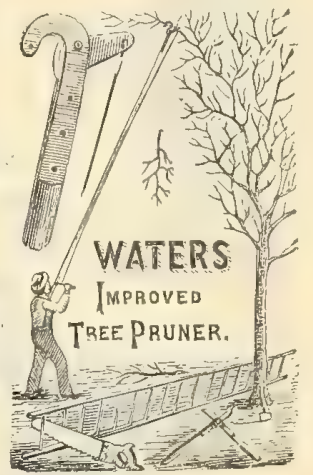

\section{IRON GARDEN OR LAWN ROLLERS.}

\begin{tabular}{|c|c|c|c|c|c|c|}
\hline \multirow{2}{*}{2 section, } & \multicolumn{2}{|c|}{ Face } & \multicolumn{2}{|c|}{ Diam. } & \multirow{2}{*}{$\begin{array}{l}\text { Weight } \\
125 \text { Ibs. }\end{array}$} & \multirow{2}{*}{$\begin{array}{r}\text { Price } \\
\$ 600\end{array}$} \\
\hline & & & & nch, & & \\
\hline $1 \quad \because$ & 12 & " & 20 & “6 & 140 ". & 700 \\
\hline "6 & 20 & " & 20 & “ & $220 " 6$ & $\ldots 1000$ \\
\hline "6 & 12 & “ & 20 & "6 & 450 “. & .. 1800 \\
\hline “ & 12 & “ & 24 & “ & $200 "$. & 950 \\
\hline 16 & 12 & "6 & 24 & "6 & 400 ". & $\ldots 1600$ \\
\hline “ & 12 & “ & 28 & "6 & 250 ، & $\ldots 1250$ \\
\hline “ & 12 & “ & 23 & $\because$ & $500 “$ & $\ldots \ldots \ldots \ldots \ldots 1800$ \\
\hline “ & 12 & " & 28 & “ & $700 \lll$. & $\ldots \ldots \ldots \ldots \ldots 3000$ \\
\hline
\end{tabular}

\section{SIZES AND PRICES.}

\section{'TROWBRIDGE'S GRAFTING WAX.}

Put up in convenient rolls for use, $1,1 / 2$ and $1 / 4$ pounds. This has been in use for a number of years and is highly recommended. Price, 40c. per $1 \mathrm{lb}$; $1 / 4 \mathrm{lb}$. package, 15c. By mail, 16c. per lb. extra. 
THE ISBELL MOLE TRAP.

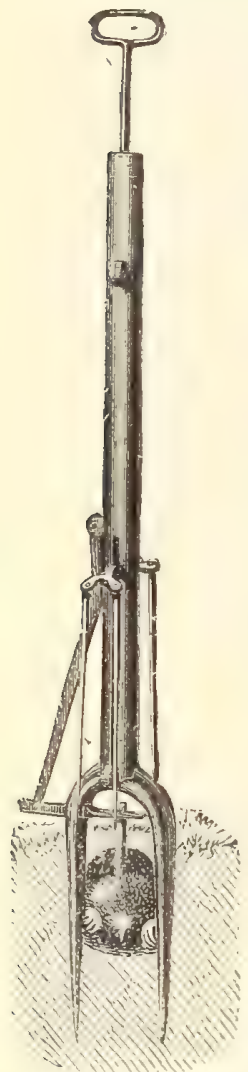

It is acknowledged by all who have given it a trial as the best trap ever invented for catching and destroying the underground mole. When properly set, it never allows the mole to escape, and no skill is required in setting it.

Price, each. .......... $\$ 200$

Per doz............. 1800

\section{TYING MATERIALS.}

Raffia...............per 1b., 25 cts.

Green Smilax Twine, 15 cts. per ball; $\$ 1.50$ per doz.

Thompson's Styptic for preventing bleeding of Vines. Per bottle, $50 \mathrm{cts}$.

\section{COCOANUT FIBRE}

\section{REFUSE.}

Valuable for mixing with soil for plants, either in beds or in pots, and a most excellent substitute for leaf mold or peat. Plants of all kinds thrive in it with the greatest luxuriance. 50 cts. per peck; $\$ 1.25$ per bushel, in bags or barrels.

\section{RUSTIC HANGING BASKETS.}

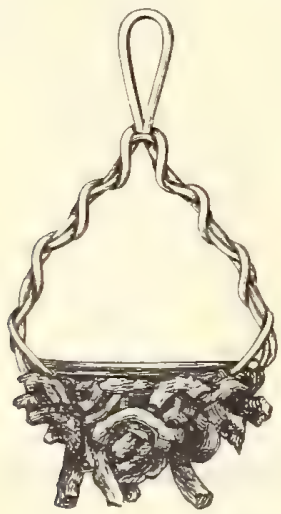

10 in. diameter

$\$ 125$ each. 50 “
WOODASON'S IMPROVED BELLOWS.
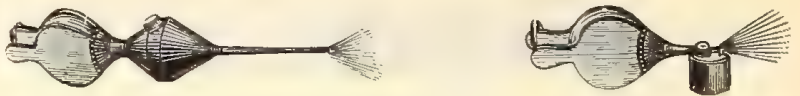

These bellows are the best ever invented for distributing poison powders for the destruction of insects in the conservatory, garden, orchard or field. It can be held in any direction without wasting powder.

Double Cone Bellows...................... \$3 00 Large single Cone Bellows, with Spreader....... 2 00 Single Cone Bellows for House Use............ 100 Liquid Atomizer Bellows, large............. 200 " " $"$ small,............ 125

" PERFECTION", GLAZIERS' POINTS.

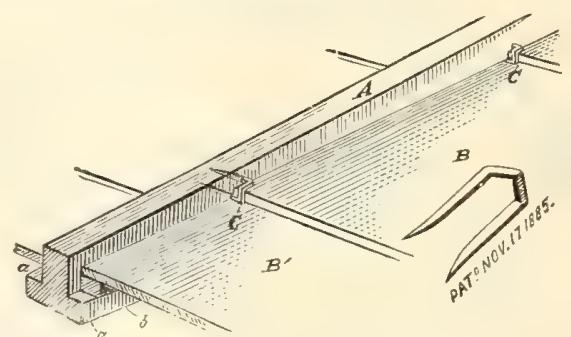

Per box of 1000 . $\$ 065$

Pincers for same....................... 40

\section{FRANCIS GLAZING POINTS.}

Per 1000 50 cts.

Glass Cutter, or Glaziers' Diamond, on Ebony Handle, with guide wheel. Makes a straight cut in the glass. Price, $\$ 3.00$ each.

\section{FIBROUS PEAT.}

Of great value for Hothouse and Greenhouse plants, and especially for Orchids.................per bbl., $\$ 225$

Loose Peat....................... 600

\section{SPHAGNUM MOSS.}

Very useful for mixing in soil for potting, also for mulching, packing, etc. Fresh moss, $\$ 1.75$ per bbl.; dry moss, for packing, etc., $\$ 1.50$ per bbl. 


\section{THERMOMETERS.}

(All tested and guaranteed.)
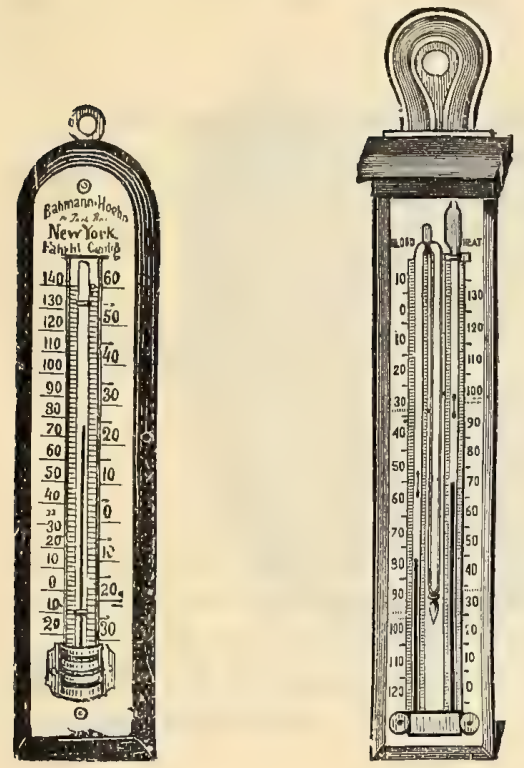

Siexe's Self-registering. Registers both heat and cold; you can tell exactly how hot or cold it has been; it is easily reset by the aid of a horse-shoe magnet which accompanies each.

Siexe's No. I. White enameled case (fig. 1 ), 8 inch, $\$ 2.50$.

Seixe's No. I. White enameled case, porcelain scale, 8 inch., \$3.25.

No. 3, Greenhouse Distance. An unusually plain, readable porcelain scale, ranging from 20 to 100 degrees, red spirits, $\$ 1.00$.

No. 4, Parlor. Boxwood case, metal scale, 12 inch, $50 \mathrm{c}$.

No. 5, Ebony. Porcelain scale, red spirits, 8 inch, $\$ 1.00$; 10 inch, $\$ 1.50 ; 12$ inch, $\$ 2.00 ; 14$ inch, $\$ 2.50$.

No. 6, Plate Glass Back. With brass supporters, allowing free circulation of air; 8 inch, $\$ 1.50 ; 10$ inch, $\$ 1.75$.

No. 7, Ordinary Japanned Tin Cases (not guaranteed); 7 inch, 15c.; 8 inch, 20c.; 10 inch, 25c.; 12 inch, 30c.

No, 8, Window. With nickel supporters, allowing free circulation of air; $9 \frac{1}{2}$ inch, $\$ 1.00$ each.

No. 9, Hot-bed and Mushroom-bed. Brass mounted and tipped, made especially for plunging, $\$ 2.00$.

\section{CANE PLANT STAKES.}

These form a valuable substitute for the more expensive plant stakes in use. They are from 6 to 8 feet in length and can be cut to any desired size. Being light and durable they are adapted for supporting roses, carnations, gladioli, etc. Price, per doz., 20.; per 100, $\$ 1.25$; per $1000, \$ 9.00$.
Round Green Tapering Stakes (Light).

Per doz. Per 100

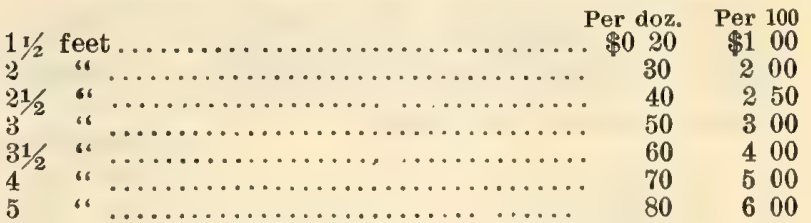

Round Green Tapering Stakes (Heavy).

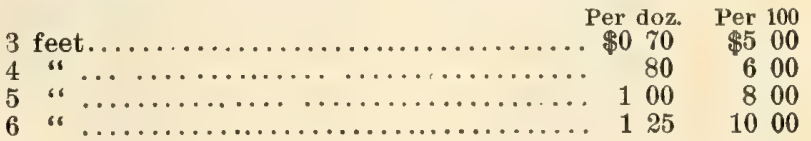

WOOD LABELS.

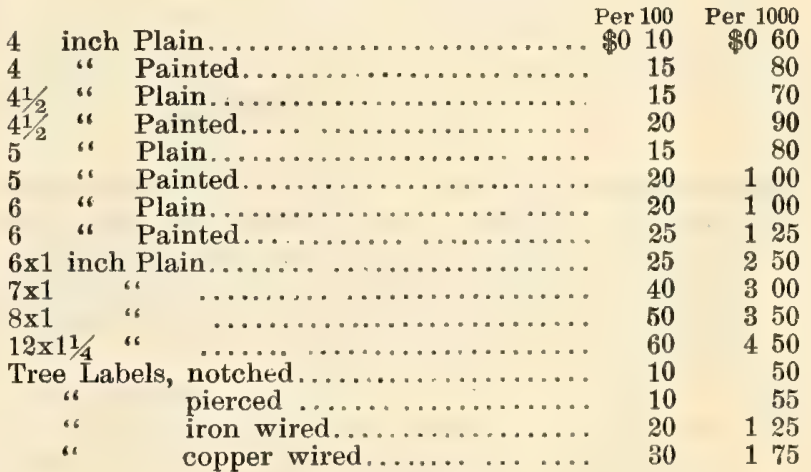

MATS.

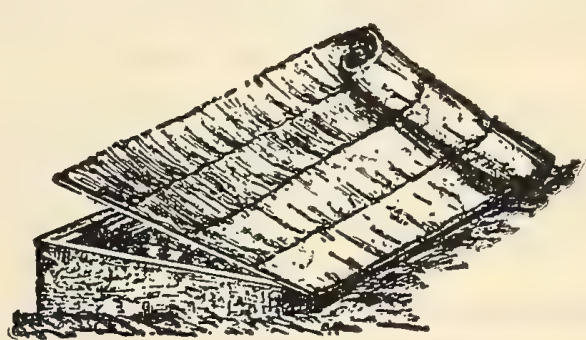

For covering hot-beds, sashes, etc. Straw Mats, 6 feet wide by 6 feet long, $\$ 1.75$ each.

Rattan indestructible. $6 \times 6, \$ 2.00$ each.

\section{WOOLF'S MARKING INK PENCILS.}

Black. The cheapest made for producing an indelible mark upon wood labels for garden purposes; $15 \mathrm{c}$. each.

\section{WORKS ON GARDENING.}

Handy Book of the Flower Garden, David Thompson. Orchid Growers' Manuel, Sixth Edition. B. S. Wil-

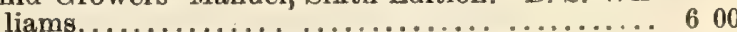

Choice Stove and Greenhouse Plants........... 300 Select Ferns and Lycopods..................... 300

The Rose. H. B. Ellwanger.................. 100 The American Fruit Culturist. J. J. Thoma....... 300 Culture of Mushroom Spawn................. 10 
"STANDARD" FLOWER POTS.

These pots are all full inside measurement, height and width, which makes them at least one size larger than by the old way of measuring. Breakage is not one-half as great as in other pots, the deep ring protecting them from any ordinary hard usage.

\begin{tabular}{|c|c|c|c|}
\hline & & 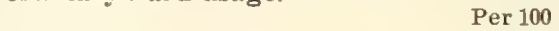 & Per 1000 \\
\hline 21 & inch, & , Thumb.. & $\$ 650$ \\
\hline & & 100 & 800 \\
\hline 4 & 66 & Half pint. & 1400 \\
\hline 5 & is & . & 20 \\
\hline 6 & " & $\ldots \ldots \ldots \ldots 375$ & 3000 \\
\hline 7 & "6 & $\therefore 560$ & 45 \\
\hline & “6 & gallon................ 780 & 62 \\
\hline c & 66 & $\cdots \quad \ldots \ldots \ldots$ & 110 \\
\hline & "6 & gallons.................. 95 & \\
\hline & “ & Three gallons.. & \\
\hline & " & Four gallons........... & \\
\hline
\end{tabular}

SQUARE SEED PANS.

Per doz.

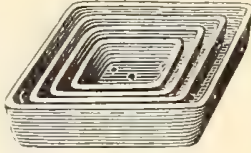

$6 \times 6$ inches, 2 in. deep...... $\$ 2.00$

$8 \times 8 \quad$ " $2 \quad$ " $8 \ldots \ldots \ldots 250$

$10 \times 10$ " " $21 / 2$ " “

$12 \times 12 \quad$ " $3 \quad$ " $\quad \ldots \ldots, \ldots 30$

ROUND SEED OR LILY PANS.

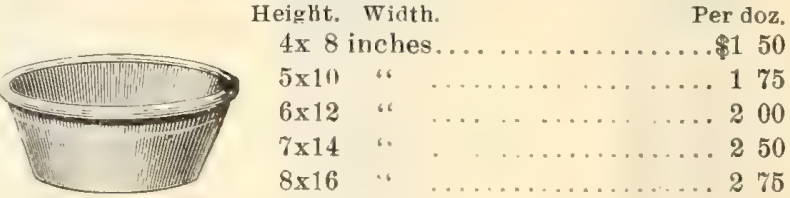

\section{Insect Exterminators.}

Australian Garden Wash. Can be used with perfect safety on the most delicate plants, and will prove invaluable to florists and gardeners, both for cleansing and fertilizing plants. As a destroyer of insect life it has no equal. Price, per pint, 50 cts.; quart, 80 cts.; balf gallon, $\$ 1.50$; gallon, $\$ 2.50$.

Fir Tree Oil. This new insect destroyer has proved to be one of the most reliable for red spider, green fly, mealy bug, caterpillars, slugs, blight, etc. Dilute with water and apply with ordinary or bellows syringe, or by dipping the plants in. Price, per pint, 75 cts.; quart, $\$ 1.50$; half gallon, $\$ 2.75$; gallon, $\$ 5.00$.

Gishurst Compound. An English preparation for green fly, scale, bark lice, mealy bug, red spider, etc. Dissolve in water and apply with ordinary syringe, or dip the plants in the solution. Price, per lb. box, 50 cts, ; 3 lb. box, $\$ 1.00$.

Hammond's Grape Dust. A preparation to kill the destructive mildew that strilkes the grape vine, affecting fruit and stems in unfavorable seasons. Also for like use upon any other plants or trees affected with mold, mildew or rust mites, and for use where a fumigater antiseptic is required, either in greenhouses or the open air. 5 lb., packet, 35 cts.; kegs of $100 \mathrm{lbs}$, $\$ 5.00$.

Fir Tree Oil Soap. For killing mealy bugs, red spider, aphis, caterpillars, and other insects that infest plants; also fleas and other insects on animals. Price, $1 / 2 \mathrm{lb}$. tin, $25 \mathrm{cts}$.

Lemon Oil Insecticide. The best and cheapest Insecticide in the market. Csed now by nearly all the leading growers. It effectually destroys mealy bug, scale, thrip and red spider. Half pint, 25 cts.; pint, 40 cts.; quart, 75 cts.; half gallon, $\$ 1.25$; gallon, $\$ 2.00$; 5 gallon kegs, $\$ 9.00 ; 10$ gallon kegs, $\$ 17.50$.
Fostite. For the prevention and cure of mildew and black rot on grapes, potatoes, cabbage, beet roots, roses, verbenas, cineraries, carnations, etc. Svrprising results have been obtained by its use for the destruction of insects, such as leaf lice, fleas, caterpillars, etc. Price, 5 lb. packag, 50 cts.

Slug Shot. Destroys all insects injurious to house and garden plants, shrubs, trees, vines, potatoes, melons, cabbage, currants and vegetables, and fruits of all kinds. Equals Paris green where used liberally, without the danger from poison. Price, $5 \mathrm{lb}$. packet, $30 \mathrm{cts}$; 10 lb., 50 cts.; per bbl. of 235 lbs., 4 cts. per lb.

Sulphur-Flower of Sulphur. This is a staple article for greenhouse use; mixed with linseed oil and painted on the pipes it has been found a sure cure for mildew. It should be mixed to the consistency of a thick paste, and applied with a brush. In packages of 5 and 10 lbs., 40 cts. and 75 cts. each.

Tobacco Dust. This is a splendid insecticide for general use, and the best article for dusting vegetable plants, such as melons, cucumbers, etc. Pex lb., 10 cts.; 10 lb. package, 75 cts.

Tobacco Soap (Rose Brand). Makes an excellant wash for plants and trees infested with green fly, lice and eggs of insects. Dissolve two ounces in a gallon of water. Half $1 b$. tins, 25 cts.

Tobacca Stems for Fumigating. Clean and free from rubbish. In bales of $\mathrm{I} 00 \mathrm{lbs} ., \$ 1.50 \mathrm{each}, 500, \$ 6.00$.

Whale Oil Soap. Makes an excellent wash for trees and plants, kills insects and eggs on the bark. Per lb., 15 cts.; 5 lbs., 60 cts.; 25 lbs. and over, 10 cts. per lb. 


\section{RAM'S HEAD BRAND.}

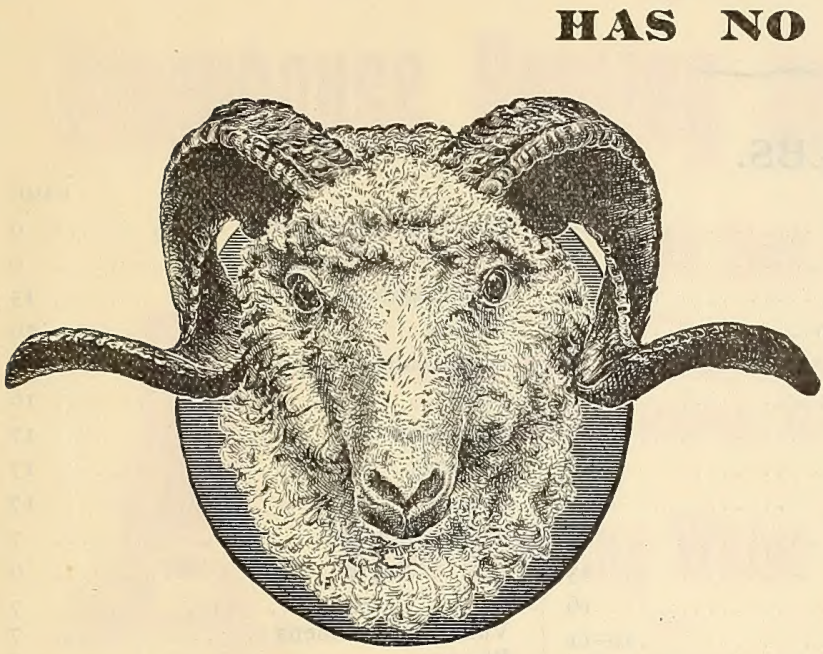

EQULA.

This is the pure Natural Manure, and the most nutritious foud for plants. Its effect is immediate; much more lasting and healthy than guano or any other manure. It is the best of manures for mixing the soil for greenhouse plants-one part manure and six parts soil. Strewn over and dug into the vegetable garden or placed directly in drills or hills, it promotes a rapid, steady growth until maturity; all culinary vegetables reach their highest quality only when growth is rapid and unchecked. It makes the richest, safest and quickest Liquid Manure, rivaling guano, without any deleterious effects. For use in liquid form, one pound to five gallons of water will make a dark liquid which can be used with safety daily if necessary. As a Lawn Top Dressing it is unequaled.

In bags of $100 \mathrm{lbs}$. each, $\$ 3.00$; $1 / 4$ ton, 5 bags, $\$ 12.50$; per ton, 20 bags, $\$ 40.00$. In packages of 2,4 and 10 lbs., $15 \mathrm{c}$., 25c. and 50c. each.

COMPRESSED MANURE.

Used chiefly for making liquid manure. In bags of $100 \mathrm{lbs}$, each, $\$ 2.75 ; 1 / 4$ ton, 5 bags, $\$ 10.00$; per ton, 20 bags, $\$ 35.00$.

\section{CLAY'S FERTILIZER.}

We have been appointed Sole Agents for this valuable imported manure, which is constantly increasing in popularity. It is especially recommended to all who grow either fruit, flowers or vegetables, and wish to bring them to the highest perfection. Per cwt. (112 lbs.), $\$ 7.00 ; 1 / 2$ cwt. (56 lbs.), $\$ 4.00$.

\section{MAPES' MANURES.}

The following well-known manures have been in successful practical use among many of the most noted truck, fruit and special crop growers, and are now employed, particularly among farmers in Long Island, Connecticut and New Jersey, by many exclusively in place of purchased stable manure. They restore wornout lands and add to the permanent fertility of the soil, as is abundantly shown by the testimony of practical growers who have used them for many successive seasons on the same land.

Mapes' Potato Manure.-For Irish and sweet potatoes, also for asparagus, early vegetables, tomatoes, sugar beets, fruits and sorghum. Use three bags per acre. Per bag, (200 lbs.), \$4.75; per ton, $\$ 43.00$.

Complete Manure (for Light Soil).-This is our vegetable or truck manure on all kinds of soils, light or heavy. Use broadcast; special for onions, also on light soils for asparagus, sweet potatoes, melons, tomatoes, wheat and seeding to grass. Per bag (200 lbs.), $\$ 5.00$; ton, $\$ 45.00$.

Complete Manure (for General Use).-For use on all crops and all soils with or without stable manure. Use broadcast; if any in hills, use sparingly. Special for oats, Hungarian grass, vegetables, melons, tomatoes and seeding with or without grain. Per bag (200 lbs.), $\$ 4.50$.
Complete Manure “A" Brand.-For use in hill or drill on all crops, particularly in connection with farm manure. Special for peas, beans, buckwheat and turnips. Per bag (200 lbs.), $\$ 4.00$; ton, $\$ 38.00$.

Fruit and Vine Manure.-For insuring fruiting power, particularly in quality of fruit in vineyards (grapes), pears, apples, plums, strawberries and all small fruits. Is slow in effects. Per bag (200 lbs.), $\$ 4.00$; ton, $\$ 38.00$.

Lawn Top Dressing (with Plaster).-Per bag (200 lbs.), $\$ 4.00$; per ton, $\$ 35.00$.

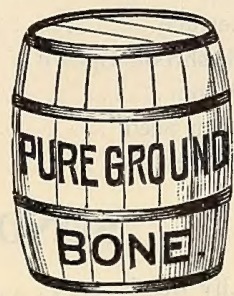

\section{PURE FINE GROUND BONE.}

This is a very pure, tinely pulverized form of ground bone, especially prepared for rose culture. It is well adapted for mixing with soil for potting purposes in the proportions of one part bone to fifty of soil. 2 lbs., 15c.; 4 lbs., 25c.; 10 lbs., 50c.; 100 lbs., $\$ 4.00$; bbl., 200 lbs., $\$ 6.00$; ton, $\$ 45.00$.

\section{PURE CRUSHED BONE.}

A coarse article, particularly well adapted for use in the preparation of grapevine borders. In barrels of about 250 lbs., $\$ 3.00$ per 100 lbs., or $\$ 45.00$ per ton of $2000 \mathrm{lbs}$.

\section{Elliott's Concentrated Plant Fertilizer.}

A natural food for growing plants either in the window or out-door garden. Endorsed by leading amateur and professional florists throughout the country. Full directions for using accompany each package. Large package, 25c.; small package, $15 \mathrm{c}$. If to be sent by Mail, large package, $45 \mathrm{c}$; small package, $30 \mathrm{c}$. 


\section{N D E X.}

\section{BULBS.}

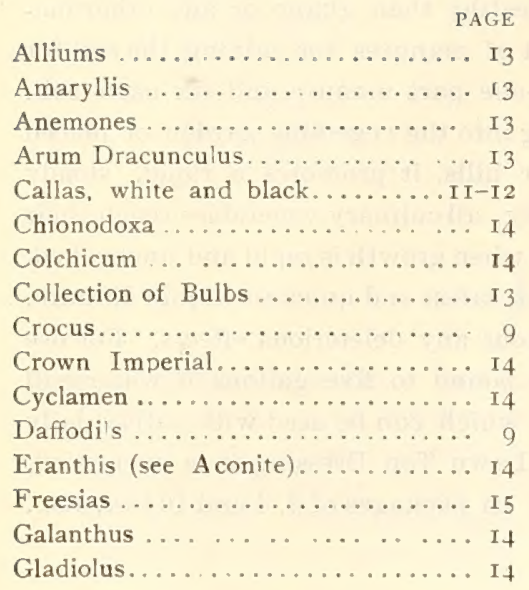

Ampelopsis................ I8

Clematis................ I 8

Decorative Plants.............. I8

Grape Vines ................ 20

Asparagus Roots. ............. 22

Beans................... 22

Beets................... 22

Cabbage................. 22

Carrot....................22

Cauliflower............... 22

Corn Salad................ 22

Cucumber.................22

Baskets, Hanging, Rustic......... 28

Books.................... 29

Crocus Pots................. 20

Cocoanut Fibre Refuse.......... 28

Fibrous Peet ............... 28

Fertilizers ................ 3 I

Food for Flowers............. 3I

Fumigators............... 27

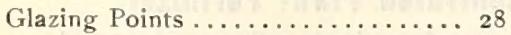

Hyacinth Glasses............. 20

Insecticides ............... 30

Knives $\ldots \ldots \ldots \ldots \ldots \ldots \ldots .26$

Lawn Invigorators. ........... $3 \mathrm{~J}$
PAGE

Gloxinias................. I 5

Helleborus ............... I 5

Hyacinths, named ........... 3 collection........... 4 mixed............ 5 Roman ............ 5 $\begin{array}{lll}\text { Roman } \ldots \ldots \ldots \ldots \ldots \ldots & 5 \\ \text { Italian } \ldots \ldots \ldots \ldots \ldots & 5\end{array}$

Iris $\ldots \ldots \ldots \ldots \ldots \ldots \ldots \ldots$

Ixias. . . . . . . . . . . . .

Jonquils ................. 9

Lachenalias.................. I5

Leucojum . . . . . . ......... I6

Lilies..................... IO-II

Lily of the Valley ............. I 2

Narcissus, single .... . . . . . . . 8

double............ 9

\section{PLANTS.}

Hydrangeas .............. I 8

Palms.................. 18

Pandanus.................. is

Roses................... I9

\section{SEEDS.}

Flower Seeds............... $2 \mathrm{I}$

Golf Mixture Grass ............ 25

Lawn Grass................. . 24

Lettuce.................. 23

Mushroom Spawn............. 23

Onion................... 23

Palm Seed .............. I 8

Parsley.................. 23

\section{SUNDRIES.}

Lily Bowls................ 20 Mole Traps..... . ........ 28 Mats, Straw ............... 29

" Bamboo............... 29

Powder Guns ................ 28

Pencils, Woolf's............... 29

Pruning Saws.............. . 26

Rubber Sprinklers ........... . 27

" Hose................. 27

Rollers, Lawn............... 27

Rakes .................... 25

Sphagnum Moss............. 28

Scissors................. 26
Narcissus, Polyanthus ........... 9

" Chinese............ 9

Ornithogalum .............. I5

Oxalis.................. 16

Ranunculus................ I6

Scilla................... 16

Snowdrops ............... I7

Sparaxis..... . . . . . . . . . . I I7

Spiræa ................. I

Tulips, double.............. 7

$"$ single .............. 6

‘ Parrot............. 7

Violet, Bybloemens ............ 7

Bizarres................. 7

Rose .................... . 7

Mixed....... ..... ... . 7

Tuberose. ............... I7

Rubber Plants ............. I8

Violets.................. 20

Shrubs, Hardy flowering......... 20

Peas ................... 23

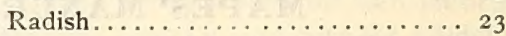

Ruta Baga ................ 23

Salsify................. 23

Spinach................. 23

Tomato................. 23

Turnip ................. 23

Stakes, Green painted........... 29

" Bamboo.. ............ 29

Seed Pans and Pots..... . . . . . 30

Shears ................... 26

Syringes $\ldots \ldots \ldots \ldots \ldots \ldots \ldots \ldots 27$

Thermometers . . . . . . . . . . . . . 29

Tools, etc................. 26

Tree Pruners............... 27

Tying Material ............. 28

Wood Labels................. 29

Watering Cans .............. 27

Wax, Gratting.............. 27 


\section{HITCHINGS \& CO.}

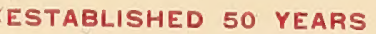

LARGEST MANUFACTURERS OF

\section{Greenhouse Heating and Ventillating Mpparatus}

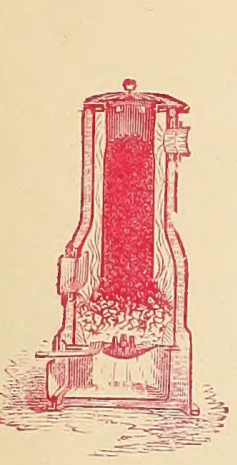

Corrugated Fire Box Heaters

LARGE GREENHOUSES, GRAPERIES, CONSERVATORIES, ETC.

Base Burning Water Heaters

SMALL GREENHOUSES, CONSERVATORIES, ETC.

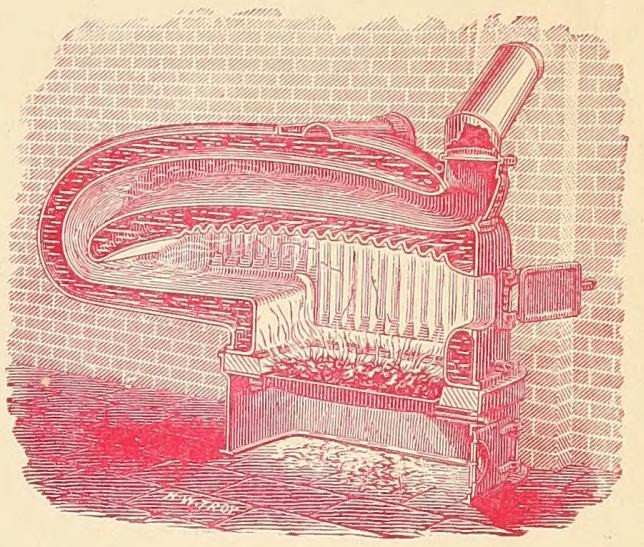

\section{Horticultural Architects and Builders.}

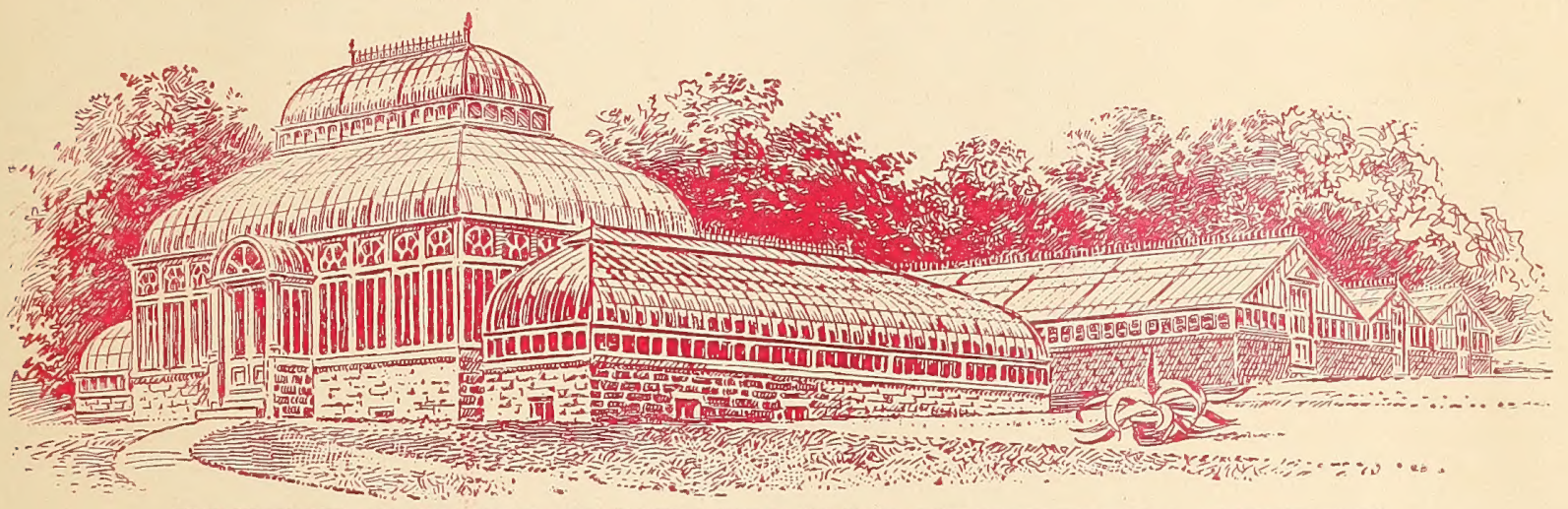

THE HIGHEST AWARDS RECEIVED AT THE WORLD'S FAIR FOR HORTICULTURAL ARCHITECTURE, GREENHOUSE CONSTRUCTION AND HEATING APPARATUS.

Greenhouses, Graperies, Rosehouses, Conservatories, Etc. constructeo wirt

IRON RAFTERS, PURLINS, BRACKETS AND COLUMNS, MAKING LIGHT, STRONG AND DURABLE STRUCTURES.

Estimates furnished for Houses complete, or for the Structural Iron Work only, with plans, details and full instructions to enable local builders to erect same.

SEND 3 CENTS POSTAGE FOR ILLUSTRATED CATALOUE

HITCHINGS \& CO., 233 Mercer Street, NEW YORK. 


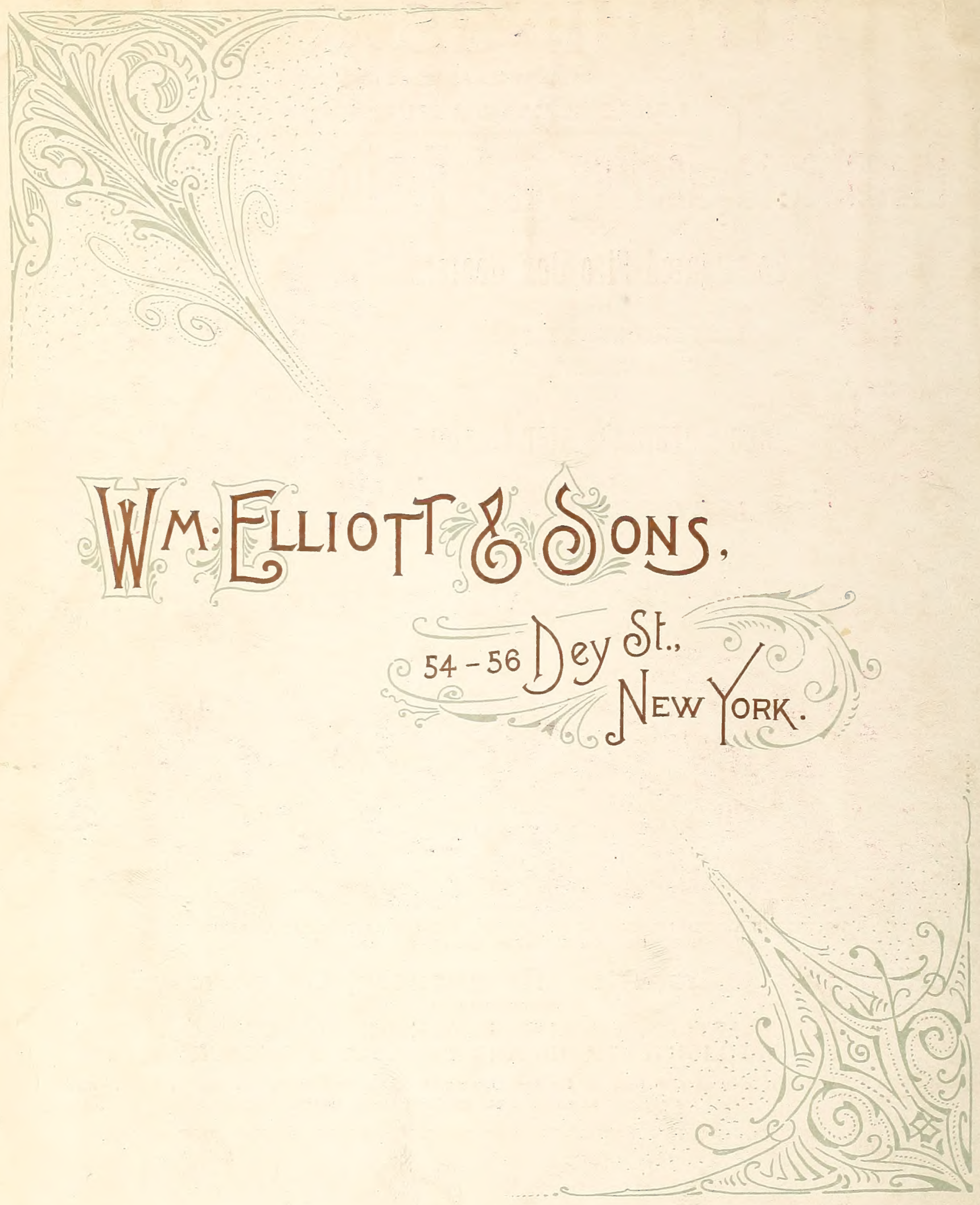

